\title{
Aluminum-based materials for advanced battery systems
}

\author{
Jiaqing Qiu, Mingming Zhao, Qunxing Zhao, Yuxia Xu, Li Zhang, Xin Lu, Huaiguo Xue and \\ Huan Pang*
}

\begin{abstract}
There has been increasing interest in developing micro/nanostructured aluminum-based materials for sustainable, dependable and high-efficiency electrochemical energy storage. This review chiefly discusses the aluminum-based electrode materials mainly including $\mathrm{Al}_{2} \mathrm{O}_{3}, \mathrm{AlF}_{3}, \mathrm{AlPO}_{4}, \mathrm{Al}(\mathrm{OH})_{3}$, as well as the composites (carbons, silicons, metals and transition metal oxides) for lithium-ion batteries, the development of aluminum-ion batteries, and nickel-metal hydride alkaline secondary batteries, which summarizes the methodologies, related charge-storage mechanisms, the relationship between nanostructures and electrochemical properties found in recent years, latest research achievements and their potential applications. In addition, we raise the relevant challenges in recently developed electrode materials and put forward new ideas for further development of micro/nanostructured aluminum-based materials in advanced battery systems.
\end{abstract}

Keywords: aluminum, battery, electrochemical, nanomaterial

\section{INTRODUCTION}

Nowadays, the environmental problems, such as pollution and global warming, are increasing rapidly, which has boosted the society to reduce reliance on fossil fuels. Therefore, it has given a great impetus to utilize renewable energy and sustainable resources. Battery technologies can store various intermittent renewable sources, such as solar and wind energy, thus achieving the goal [1-4].

Lithium-ion batteries (LIBs) are considered as the most promising electrochemical portable devices among the commercial batteries for their high energy density, no memory effect, and merely a dull loss of capacity when not in use. The advent of LIBs has led to a revolution in the wireless. Furthermore, it has stimulated intense efforts on powering electric vehicles (EVs) and hybrid electric vehicles (HEVs). Electrode materials are the key components of LIBs, which play a vital role in the overall performance [5-11]. Energy density, power density, safety, life and cost are five basic elements in the application of LIBs. Only by balancing these factors with suitable materials can we power electrochemical energy storage devices.

It is worth mentioning that aluminum is a material with great promise for LIBs due to the following superiorities. Firstly, aluminum has considerably high theoretical capacity $\left(\sim 993 \mathrm{~mA} \mathrm{~h} \mathrm{~g}^{-1}\right)$, and its volume expansion is merely about 97\% [12-14]. Secondly, the steady power output of LIBs using aluminum-based (Al-based) materials can be indicated by the flat and wide plateaus in the charge-discharge curves. Finally, aluminum is the most abundant metal in the Earth. It is cheap and environment-friendly, encouraging a broader range of applications of LIBs.

On the other hand, with the rapidly emerging market of LIBs, there is a huge consumption in lithium resources each year, which will further aggravate the shortage of lithium resources [15]. Recently, a large number of studies have been focusing attention on alternative battery systems, such as aluminum-ion (Al-ion) batteries (AIBs), which have similar operating principles as LIBs. Moreover, three electron transfers are involved in the Al-based redox couple during the electrochemical charge/discharge process, so that the AIB possesses competitive storage capacity comparing to the single-electron LIB. The electrochemical equivalent of an Al-based redox couple $\left(8.04 \mathrm{~A} \mathrm{~h} \mathrm{~cm}^{-3}\right)$ is $5.98 \mathrm{~A} \mathrm{~h} \mathrm{~cm}^{-3}$ higher than that of lithium [16]. But identifying an inexpensive ionic liquid electrolyte is still exploring, and finding suitable cathode materials for simple ions to transport in a reversible manner remains a challenge. Even so, the obvious advantages of AIBs still make them more attractive for future power source development.

Apart from the advanced LIBs and new rechargeable 
AIBs, nickel-metal hydride (Ni-MH) alkaline secondary batteries also have attracted much attention. They have superb power density, high specific energy, smooth discharge platform, and are nontoxic and environmental-friendly. Besides, they exhibit good electrochemical property at low temperature. These advantages make them become one of the most potential devices for EVs and HEVs applications as well.

Numerous researches have focused on Al-based materials in rechargeable batteries. The creative and rational design of unique nanoarchitectures in Al-based materials help address many issues encountered during the electrochemical reactions. In this review, we highlight recent applications of Al-based materials on the development of LIBs $\left(\mathrm{Al}_{2} \mathrm{O}_{3}, \mathrm{AlF}_{3}, \mathrm{AlPO}_{4}, \mathrm{Al}-\mathrm{Si}\right.$ alloy, etc.), AIBs (the evolution and selection of electrolyte and cathode materials) and $\mathrm{Ni}-\mathrm{MH}$ alkaline secondary battery (merit and demerit of nickel aluminum layered double hydroxide materials and the improvement by doping with various other materials). In addition, we will discuss the progress and give our insight toward these batteries based on the literature studies.

\section{Al-BASED NANOSTRUCTURES AS ELECTRODE MATERIALS FOR LIBS}

\section{$\mathrm{Al}_{2} \mathrm{O}_{3}$}

It is the key to the next generation of high-energy LIBs to develop excellent electrode materials with low cost and high energy density. Recently, various oxides such as lithium manganese-based oxides, lithium trivanadate $\left(\mathrm{LiV}_{3} \mathrm{O}_{8}\right)$, nanostructured silicon materials [17-27], carbon materials such as graphite, carbon nanotubes (CNTs) and other materials are considered to be promising materials for large-scale production due to their environmental benignity, safety, good rate capability and cost-effective application for rechargeable LIBs. However, for lithium manganese-based oxides, such as spinel $\mathrm{LiMn}_{2-x} \mathrm{Ni}_{x} \mathrm{O}_{4}$ $(0<x \leq 0.5)$ cathode oxides, the high operating voltage $(\sim 4.7 \mathrm{~V})$ always results in serious electrolyte decomposition and a thick solid-electrolyte interphase (SEI) layer on the electrode surface with weak electronic and lithium conductivity [28-32]. So when charged to $4.5 \mathrm{~V}$ or higher, lithium manganese-based oxides, show appreciable capacity fade during cycling. In addition, they suffer from Mn dissolution, leading to material loss through corrosion. So the cycle ability of the materials has not been sufficient enough as a commercial cathode. Besides, the commercial use of $\mathrm{Si}$ anode materials in LIBs is severely hindered by some problems, including enormous volume expansion and contraction resulted from lithium insertion and extraction, surface side reactions, the electrochemical agglomeration, and irreversible trapping caused by plentiful drawbacks [32].

To date, numerous strategies have been used to overcome the aforementioned problems, for example, optimized preparation methods [33], surface modification [34], fabrication of nano-sized materials [35], and tuning of crystal planes [36]. These methods can effectively improve Coulombic efficiency, high-rate capability and cycle performance. Among the approaches mentioned above, surface modification is particularly noticed on account of its simplicity and flexibility. It can reduce the side reaction and form stable SEI layers on the materials surface. As coating materials, carbon, metals, metal oxides, fluorides and phosphates [37-45], all of them have the ability to improve the electrochemical property. Among them, $\mathrm{Al}_{2} \mathrm{O}_{3}$ has always been regarded as one of the most popular coating materials because of the rich resources of aluminum, the low price of the raw materials, and the ease of film deposition. Besides, some metals, such as $\mathrm{Cu}$, can improve capacity retention, but is inactive to $\mathrm{Li}$, which will result in the detraction of the storage capacity. And carbon coating can improve the electrochemical stability of Si electrode materials, but sometimes the maximum storage capacity is reduced by $\mathrm{Si}$, thus the total capacity shows no noticeable enhancement. $\mathrm{Al}_{2} \mathrm{O}_{3}$ is an inactive metal oxide material, the increasing thickness of $\mathrm{Al}_{2} \mathrm{O}_{3}$-coating layer will degrade the property of electrodes. However, several groups have demonstrated that coating with proper $\mathrm{Al}_{2} \mathrm{O}_{3}$ can mitigate unfavorable side reactions, maintain structure, enhance electrical conductivity, improve the rate capability and extend the electrode cycle life. Furthermore, a $\mathrm{LiAlO}_{2}$ material has been prepared which shows outstanding $\mathrm{Li}$-ion transport properties at the engineered interfaces.

Generally speaking, the reasons for the improvement in electrochemical properties are mainly attributed to two aspects. First, the $\mathrm{Al}_{2} \mathrm{O}_{3}$-coating layer is able to keep the active core material from contacting with the electrolyte directly and prevent the dissolution of metal ions, which brings about improvement of cycling stability even at a high cut-off voltage $[33,46]$. Second, the existence of the coating layer can keep up more oxygen vacancies generated in the process of the initial charge, leading to more Li ions insertion. As a consequence, the rate capability will increase in the charge/discharge process $[40,44,47]$. During cycling, the thin $\mathrm{Al}_{2} \mathrm{O}_{3}$ layer can also reduce the charge transfer resistance and stabilize the surface structure of active material. Compared with the pristine one, the electrochemical 
performance can be improved obviously.

For instance, Kim et al. [48] presented that $\mathrm{LiNi}_{0.5} \mathrm{Mn}_{1.5} \mathrm{O}_{4}$ (LNMO) particles were successfully coated with ultrathin $(<1 \mathrm{~nm}) \mathrm{Al}_{2} \mathrm{O}_{3}$ by atomic layer deposition (ALD). The $\mathrm{Al}_{2} \mathrm{O}_{3}$ ALD coated LNMO showed signally improved electrochemical performance at $30^{\circ} \mathrm{C}$. The SEI layer on it was not only much thinner but also involved fewer organic species than that on the bare LNMO (Fig. $1 \mathrm{a}, \mathrm{b})$, which was responsible for inhibition of the side reaction at high voltages. In addition, Huang et al. [49] a

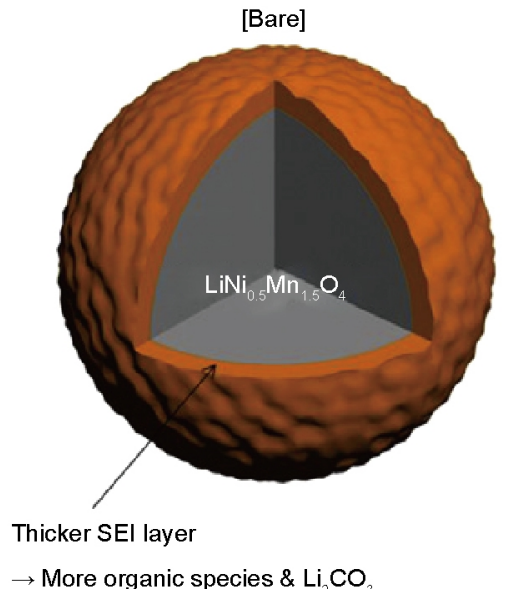

$\rightarrow$ More organic species \& $\mathrm{Li}_{2} \mathrm{CO}_{3}$
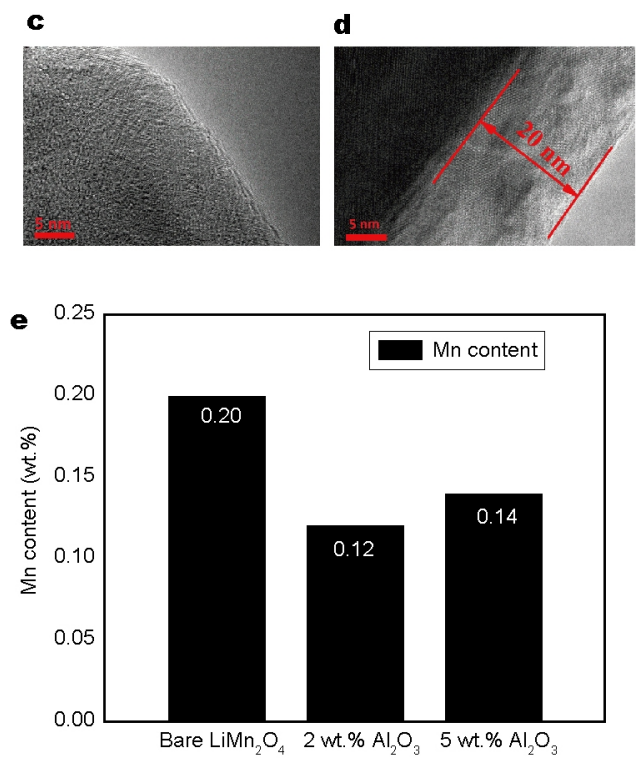

$\mathbf{g}$

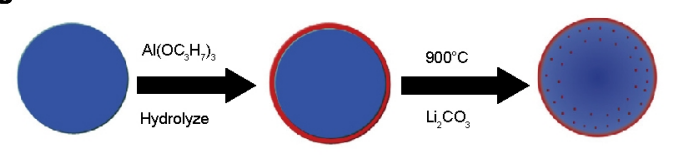

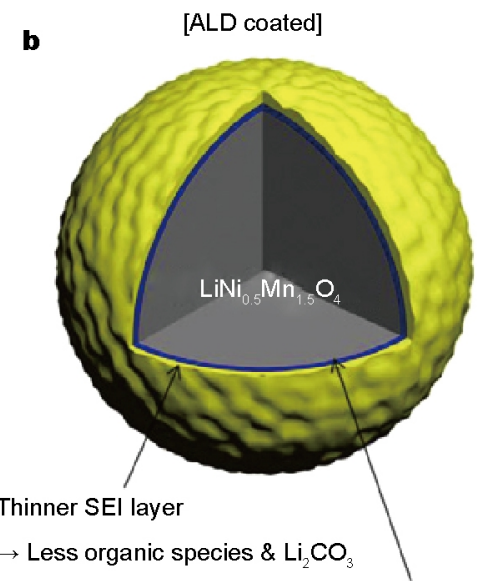

Partially fluorinated $\mathrm{Al}_{2} \mathrm{O}_{3}$

ALD coating layer
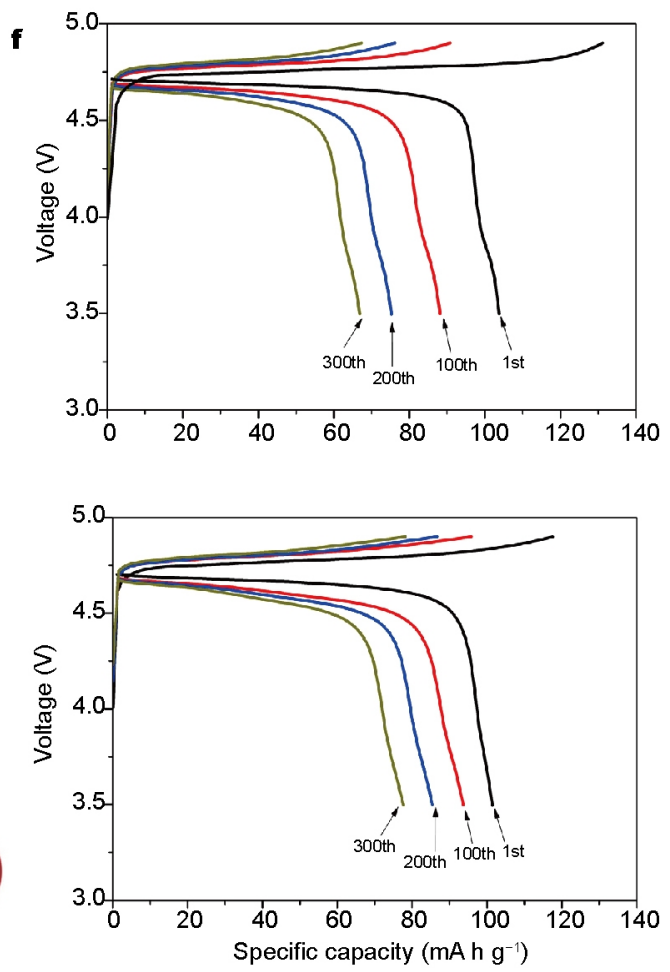

Figure 1 Schematic illustration of (a) bare and (b) $\mathrm{Al}_{2} \mathrm{O}_{3}$ ALD coated LNMO electrodes after charge/discharge cycling. Transmission electron microscope (TEM) patterns of (c) the pristine, and (d) 1 at.\% $\mathrm{Al}_{2} \mathrm{O}_{3}$-coated samples. (e) Quantitative X-ray fluorescence (XRF) analysis of Mn and Mn-containing compound deposited in the SEI layer on the surface of lithium anode and dissolved from (1) bare $\mathrm{LiMn}_{2} \mathrm{O}_{4}$, (2) 2 wt.\% $\mathrm{Al}_{2} \mathrm{O}_{3}$ coated LiMn $\mathrm{O}_{4}$, and (3) 5 wt. $\% \mathrm{Al}_{2} \mathrm{O}_{3}$ coated $\mathrm{LiMn}_{2} \mathrm{O}_{4}$ during 25 cycles. (f) Charge-discharge $(0.5 \mathrm{C})$ curves of (1) the pristine, (2) 1 at. $\% \mathrm{Al}_{2} \mathrm{O}_{3}$-coated samples at room-temperature. (g) Two-step method for the synthesis of $\mathrm{LiAlO}_{2}$-surface modified $\mathrm{LiMn}_{1.58} \mathrm{Ni}_{0.42} \mathrm{O}_{4}$ microspheres. (a and b) Reproduced with permission from Ref. [48]. Copyright 2015, Elsevier. (c, d and f) Reproduced with permission from Ref. [49]. Copyright 2014, Elsevier. (e) Reproduced with permission from Ref. [39]. Copyright 2012, Elsevier. (g) Reproduced with permission from Ref. [53]. Copyright 2013, Elsevier. 
presented the effects of high-voltage spinel LNMO material coated with $\mathrm{Al}_{2} \mathrm{O}_{3}$ via a novel carbamide-assistant hydrothermal process followed by a heat treatment. The coated ones did not change crystal structure as well as microstructure compared with the pristine sample (Fig. 1c, d), but it delivered significantly enhanced capacity retentions (Fig. 1f), especially at high temperature. $\mathrm{Li}\left(\mathrm{Ni}_{1 / 3} \mathrm{Mn}_{1 / 3} \mathrm{Co}_{1 / 3}\right) \mathrm{O}_{2}$ particles were successfully coated with thin layers of $\mathrm{Al}_{2} \mathrm{O}_{3}$ by Riley [50], Huang [51], and Fey et al. [52]. The electrochemical property was greatly improved at a high cut-off voltage of $4.5 \mathrm{~V}$ after the formation of $\mathrm{Al}_{2} \mathrm{O}_{3}$ surface film. Kim et al. [39] reported that bare $\mathrm{LiMn}_{2} \mathrm{O}_{4}$ surface could form a thin $\mathrm{Al}_{2} \mathrm{O}_{3}$ layer by electrostatic attraction forces. The cycle performance of $\mathrm{LiMn}_{2} \mathrm{O}_{4}$ with uniform and ultrathin $\mathrm{Al}_{2} \mathrm{O}_{3}$ coating on the surface is observably enhanced via inhibiting the $\mathrm{Mn}$ dissolution under high temperature. For the reduction of $\mathrm{Mn}$ dissolution (Fig. 1e), the $\mathrm{Al}_{2} \mathrm{O}_{3}$ coated $\mathrm{LiMn}_{2} \mathrm{O}_{4}$ samples display better structural stability. As a result, the charge transfer resistance of the $\mathrm{Al}_{2} \mathrm{O}_{3}$ coated $\mathrm{LiMn}_{2} \mathrm{O}_{4}$ is much less than that of the bare $\mathrm{LiMn}_{2} \mathrm{O}_{4}$. Moreover, $\mathrm{LiAlO}_{2}$-surface modified spinel cathode material such as $\mathrm{LiMn}_{1.58} \mathrm{Ni}_{0.42} \mathrm{O}_{4}$, has been synthetized by a two-step procedure for LIBs (Fig. 1g). The formed $\mathrm{LiAlO}_{2}$ coating layer is able to offer a stable interface between electrolyte and electrode. The material exhibits remarkable electrochemical property, especially in the cyclability and rate capability. These results demonstrate that this method is facile and effective to improve the electrochemical property of $5 \mathrm{~V}$ spinel cathode oxides for high-powered LIBs [53].

The principle is also suitable for nanostructured silicon materials, layered $\mathrm{LiV}_{3} \mathrm{O}_{8}$, organics, CNTs material and so on. Silicon nanowires ( $\mathrm{Si} \mathrm{NWs}$ ) have been used as electrode materials in LIBs half-cells. Memarzadeh et al. [54] investigated the influence of aluminum coating layers. Fig. 2a reveals that the surface roughness was increased with aluminum coatings. The cycling performance of Si NWs was enhanced when Si NWs were coated with 3 and 8 wt.\% aluminum. Besides, Hwang et al. [55] demonstrated that micron-scale nanostructured $\mathrm{Si} / \mathrm{Al}_{2} \mathrm{O}_{3}$ foam particles can be synthesized via chemical etching and a selective thermal oxidation process from Al-Si alloy. As a LIB anode, the synthesized $\mathrm{Si} / \mathrm{Al}_{2} \mathrm{O}_{3}$ foam exhibits excellent cycling stability, with a capacity retention of $78 \%$ at the $\mathrm{C} / 5$ rate after 300 cycles. The rate capability is outstanding as well. The volume expansion also can be effectively alleviated during long-term cycling (Fig. 2d, e).

Since 1950s, when the layered $\mathrm{LiV}_{3} \mathrm{O}_{8}$ cathode material came to light, it has also attracted great attention because it is inexpensive and possesses high discharge capacity [56-58]. However, the existence of incomplete reversible phase transformation and local structural damage result
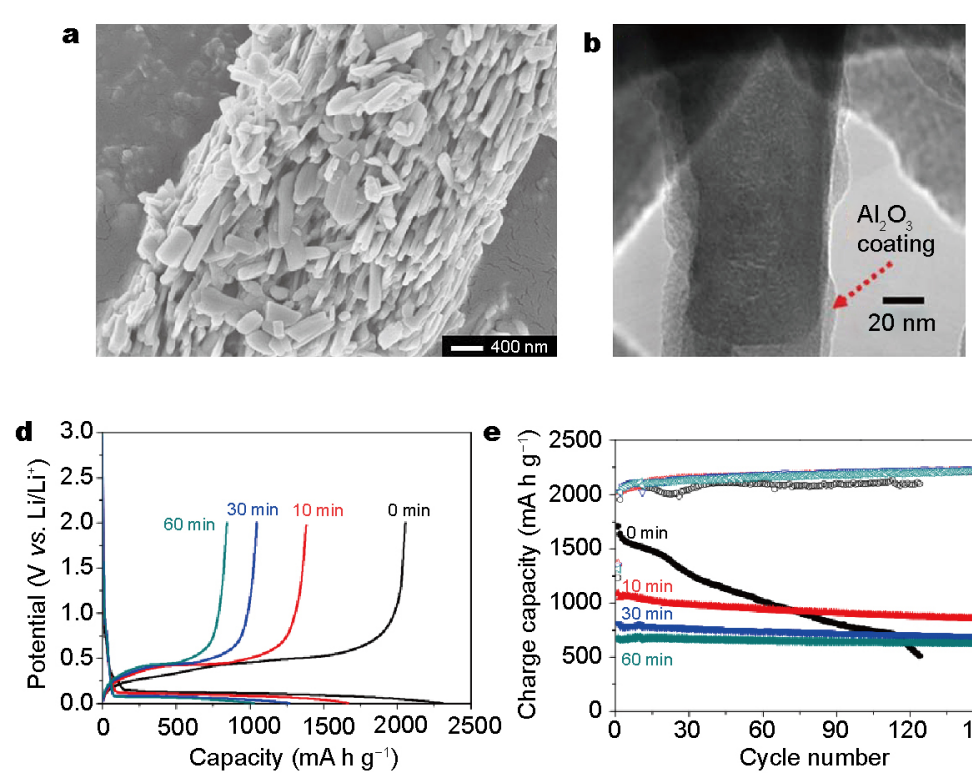

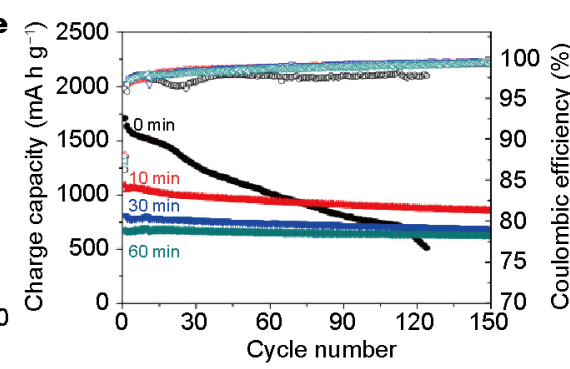

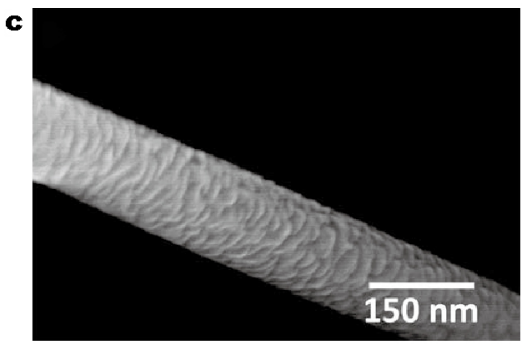

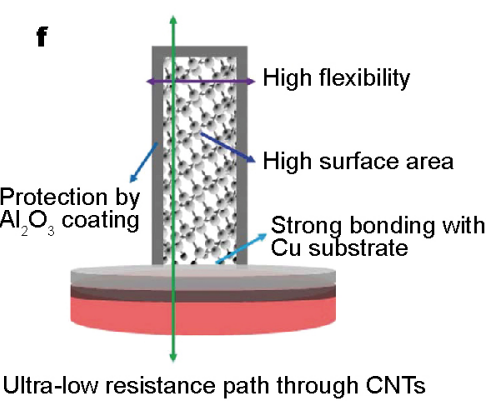

Figure 2 (a) Scanning electron microscope (SEM) images of $3 \mathrm{Al} / \mathrm{SiNWs}$. (b) SEM images of the $\mathrm{Al}_{2} \mathrm{O}_{3}$-coated $\mathrm{LiV}_{3} \mathrm{O}_{8}$ powders. (c) TEM image of single CNTs with ultrathin $\mathrm{Al}_{2} \mathrm{O}_{3}$ coatings. (d) First cycle voltage profiles at the $\mathrm{C} / 20$ rate. (e) Cycle performances at the $\mathrm{C} / 5$ rate for etched $\mathrm{Al}-\mathrm{Si}$ and thermally oxidized $(10,30$, and $60 \mathrm{~min}) \mathrm{Si} / \mathrm{Al}_{2} \mathrm{O}_{3}$ electrodes. (f) Schematic illustration showing the benefits provided by $\mathrm{Al}_{2} \mathrm{O}_{3}$-coated CNTs anode on the $\mathrm{Cu}$ current collector. (a) Reproduced with permission from Ref. [54]. Copyright 2012, the Royal Society of Chemistry. (b) Reproduced with permission from Ref. [61]. Copyright 2013, Elsevier. (c and f) Reproduced with permission from Ref. [68]. Copyright 2011, the Royal Society of Chemistry. (d and e) Reproduced with permission from Ref. [55]. Copyright 2015, the Royal Society of Chemistry. 
in poor rate capability and serious capacity loss during the insertion of lithium [59,60]. Herein, Huang et al. [61] reported that the performance of layered $\mathrm{LiV}_{3} \mathrm{O}_{8}$ cathode material could be enhanced when surface modified with $\mathrm{Al}_{2} \mathrm{O}_{3}$. They have synthesized surface modified- $\mathrm{LiV}_{3} \mathrm{O}_{8}$ materials by a simple thermolysis method. Apart from serving as a protective layer, the $\mathrm{Al}_{2} \mathrm{O}_{3}$ coating made a $\mathrm{Li}-\mathrm{V}-\mathrm{Al}-\mathrm{O}$ solid solution form at the $\mathrm{LiV}_{3} \mathrm{O}_{8} / \mathrm{Al}_{2} \mathrm{O}_{3}$ interface, which offered a faster $\mathrm{Li}^{+}$diffusion path (Fig. $2 \mathrm{~b})$, so that it could polish up the electrochemical performance. For the 0.5 wt. $\% \mathrm{Al}_{2} \mathrm{O}_{3}$-coated $\mathrm{LiV}_{3} \mathrm{O}_{8}$ electrode, even if the current densities reached up to 2000 and 3000 $\mathrm{mA} \mathrm{g}^{-1}$, the specific discharge capacities could still attain 139.4 and $118.5 \mathrm{~mA} \mathrm{~h} \mathrm{~g}^{-1}$ after 100 cycles. Mo et al. [62] demonstrated that unique $\mathrm{Al}_{2} \mathrm{O}_{3}$-modified $\mathrm{LiV}_{3} \mathrm{O}_{8}$ nanosheets were successfully synthesized via a simple and cost-effective strategy based on a hydrothermal process and layer-by-layer self-assembly. Compared to $\mathrm{LiV}_{3} \mathrm{O}_{8}$ nanosheets, $\mathrm{Al}_{2} \mathrm{O}_{3}$-modified $\mathrm{LiV}_{3} \mathrm{O}_{8}$ nanosheets exhibited far better lithium-storage properties. The thickness of $\mathrm{Al}_{2} \mathrm{O}_{3}$ nanolayer influenced the electrochemical performance of the $\mathrm{Al}_{2} \mathrm{O}_{3}$-modified $\mathrm{LiV}_{3} \mathrm{O}_{8}$ nanosheets, which proved that proper surface modification could enhance physical and/or chemical properties. The $\mathrm{LiV}_{3} \mathrm{O}_{8}$ with proper $\mathrm{Al}_{2} \mathrm{O}_{3}$ coating as the cathode material has a great promise for its application in high-power LIBs.

Besides, Lee et al. [63] synthesized a nonwoven polyimide (PI) separator which sandwiched between thin $\mathrm{Al}_{2} \mathrm{O}_{3}$ overlayers via an electrospinning strategy and dip-coating of $\mathrm{Al}_{2} \mathrm{O}_{3}$ nanopowders subsequently. The $\mathrm{Al}_{2} \mathrm{O}_{3}$-coated $\mathrm{PI}$ separator showed a high capacity and excellent rate capability on account of the PI inner membrane, and a restrictive increase of cell impedance during long time cycling because of the $\mathrm{Al}_{2} \mathrm{O}_{3}$ surface layer.

CNTs are highlighted as the possible electrode materials [64-67]. The $\mathrm{Al}_{2} \mathrm{O}_{3}$-coated $\mathrm{CNTs}$ have been successfully prepared on a copper substrate and tested as a LIB anode [68]. CNTs can form the binder-free electrode for LIBs since they grow on the copper current collector directly via chemical vapor deposition. Then the ultrathin $\mathrm{Al}_{2} \mathrm{O}_{3}$ layer will be deposited on the CNTs via ALD (Fig. 2c). CNTs can form the core of the structure, thus providing outstanding conductivity, integrality of structure, and $\mathrm{Li}$-ion intercalation ability. Meanwhile, the $\mathrm{Al}_{2} \mathrm{O}_{3}$ coating reinforces the stability of electrode additionally, leading to further improvement of capacity. The novel anode exhibits excellent electrochemical performance and has been considered as a potential anode for the prospective LIBs (Fig. 2f).
$\mathrm{AlF}_{3}$

Fluoride is an optional additive to protect electrode. As well known, the erosion action of $\mathrm{HF}$ and the accumulation of $\mathrm{LiF}$ are two main factors in deteriorating the electrochemical property of electrode materials. Fluoride can work as a protective layer while free fluoride ions reduce the formation of LiF film, which enhance the cycle lives of cathode materials. $\mathrm{LiF}$ is an electronic insulator. In previous studies, LiF coating, acting as HF inhibitor, was demonstrated to effectively improve cycle performance and the rate capability of lithium manganese-based oxides electrode materials during cycling $[69,70]$. $\mathrm{AlF}_{3}$ has also been extensively used to improve the electrochemical performance of layered cathode materials by coating strategy. Particularly, $\mathrm{AlF}_{3}$ has stable and strong $\mathrm{Al}-\mathrm{F}$ bonds, which can negate the oxygen activity on the surface of the cathode materials during cycling. Owing to these $\mathrm{Al}-\mathrm{F}$ bonds, $\mathrm{AlF}_{3}$ has excellent ionic conductivity and can enhance the rate capability, capacity, retention, and thermal stability of the cathode materials [71-75]. For instance, the electrochemical property of Li-rich layered oxides (LRO) can be enhanced via coating $\mathrm{AlF}_{3}$ on the surface [76].

$\mathrm{Wu}$ et al. [77] presented a simple synthesis of $\mathrm{AlF}_{3}$-modified LMNO cathode materials by chemical deposition. The $\mathrm{AlF}_{3}$ surface modified one showed no change on the bulk structure compared to the pristine one. They yet showed improved cycle stabilities, especially the $1 \mathrm{wt} . \%$ sample. The sample possessed the best reversibility relatively, and a capacity retention ratio of $93.6 \%$ after 50 cycles, while that of the pristine one was only $77.6 \%$. The electrochemical performance of the $\mathrm{AlF}_{3}$ coated $\mathrm{Li}\left(\mathrm{Li}_{0.17} \mathrm{Ni}_{0.25} \mathrm{Mn}_{0.58}\right) \mathrm{O}_{2}$ [33], $\mathrm{Li}\left[\mathrm{Ni}_{0.8} \mathrm{Co}_{0.15} \mathrm{Al}_{0.05}\right] \mathrm{O}_{2}$ (Fig. 3a-f) [78], $\mathrm{Li}\left[\mathrm{Li}_{1 / 9} \mathrm{Ni}_{1 / 3} \mathrm{Mn}_{5 / 9}\right] \mathrm{O}_{2}$ [79], $\quad \mathrm{Li}\left[\mathrm{Li}_{0.19} \mathrm{Ni}_{0.16} \mathrm{Co}_{0.08} \mathrm{Mn}_{0.57}\right] \mathrm{O}_{2}$ [80], $\mathrm{Li}_{1.1} \mathrm{Al}_{0.05} \mathrm{Mn}_{1.85} \mathrm{O}_{4}$ [81], $\mathrm{LiMn}_{2} \mathrm{O}_{4}$ [82] and other spinels were also investigated. Compared to the pristine one, the $\mathrm{AlF}_{3}$-coated sample generally has a markedly enhanced electrochemical property (Fig. 3k). The fundamental functions of the $\mathrm{AlF}_{3}$ coating can be summarized as follows. First, similarly to $\mathrm{Al}_{2} \mathrm{O}_{3}$, an $\mathrm{AlF}_{3}$ coating layer holds back the active material from directly contacting with the electrolytes, thus greatly reducing the formation of SEI layers. Second, $\mathrm{AlF}_{3}$ coating enhances structure stability of the electrode materials and mitigates the phase transformation from layered to spinel-like structure, significantly improving stability of voltage profiles during cycling. Finally yet importantly, the coating layer effectively protects the spinel-like phase from attack by the acidic species in the electrolyte. Materials with such coatings can maintain more than 100 cycles without identifiable capacity degradation [83]. 


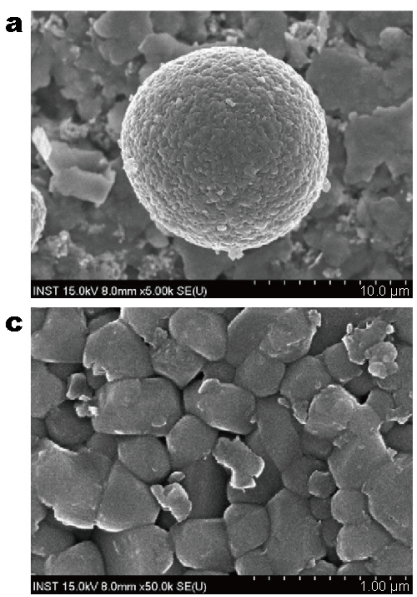

e

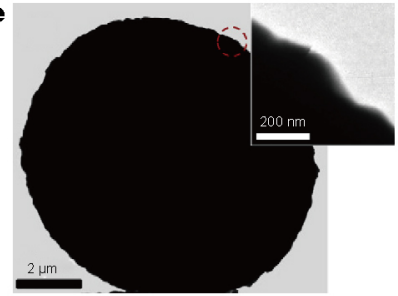

$\mathbf{g}$
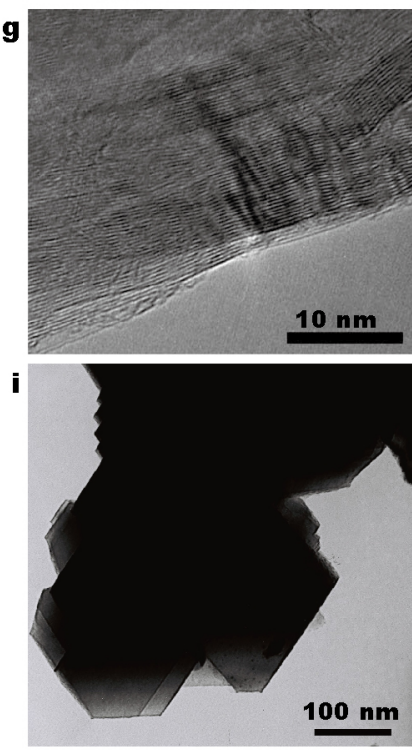
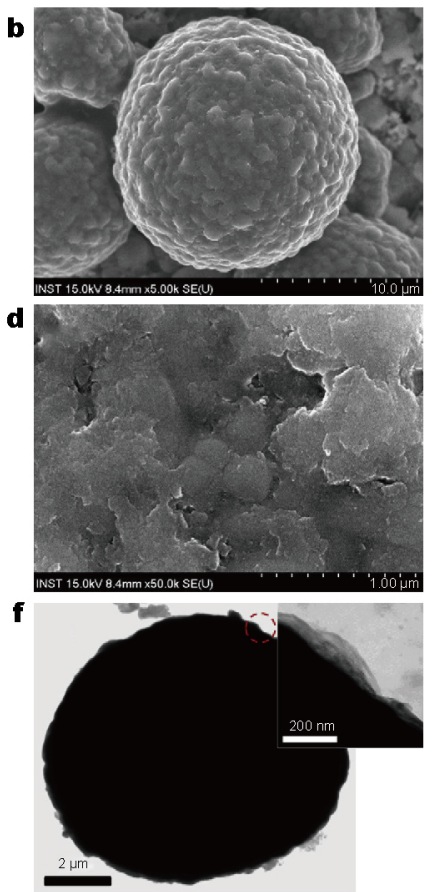

h
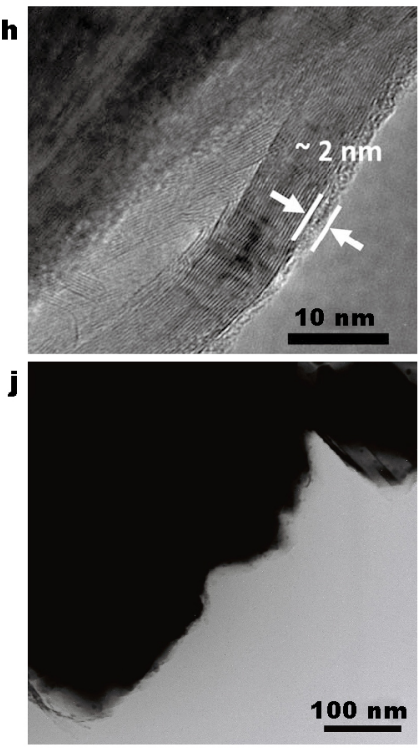
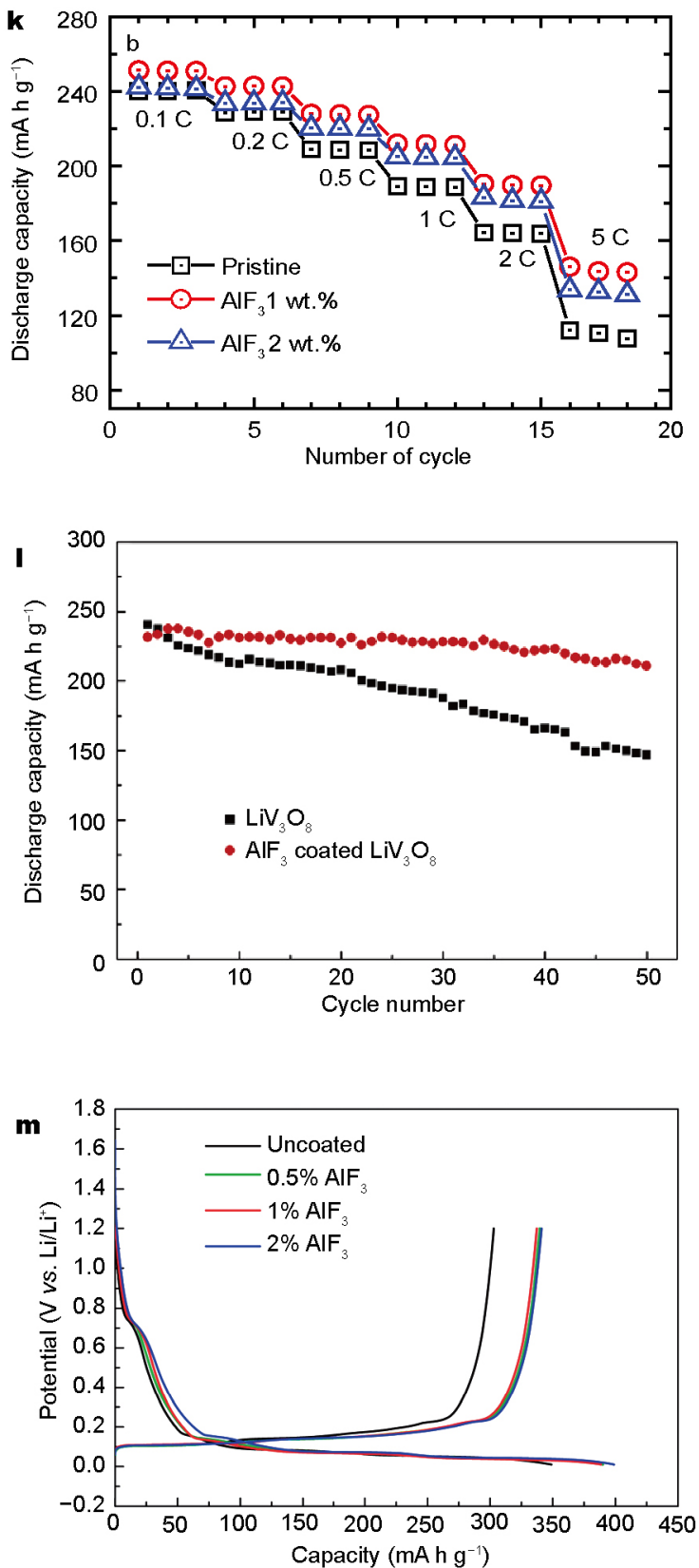

Figure 3 (a) SEM images of the pristine $\mathrm{Li}\left[\mathrm{Ni}_{0.8} \mathrm{Co}_{0.15} \mathrm{Al}_{0.05}\right] \mathrm{O}_{2}$ and (b) $\mathrm{AlF}_{3}$-coated $\mathrm{Li}\left[\mathrm{Ni}_{0.8} \mathrm{Co}_{0.15} \mathrm{Al}_{0.05}\right] \mathrm{O}_{2}$. (c) Magnified images of (a). (d) Magnified images of (b). TEM images of (e) the pristine $\mathrm{Li}\left[\mathrm{Ni}_{0.8} \mathrm{Co}_{0.15} \mathrm{Al}_{0.05}\right] \mathrm{O}_{2}$ and (f) $\mathrm{AlF}_{3}$-coated $\mathrm{Li}\left[\mathrm{Ni}_{0.8} \mathrm{Co}_{0.15} \mathrm{Al}_{0.05}\right] \mathrm{O}_{2}$. TEM images of (g) uncoated graphite powders, (h) $2 \% \mathrm{AlF}_{3}$-coated graphite powders. (i) Pure $\mathrm{LTO}$, (j) $\mathrm{AlF}_{3}$-modified LTO. (k) Rate capability of the pristine, 1 wt.\% $\mathrm{AlF}_{3}$-coated and 2 wt.\% $\mathrm{AlF}_{3}$-coated electrodes. (l) Cycle performance of the bare and $\mathrm{AlF}_{3}$-coated $\mathrm{LiV}_{3} \mathrm{O}_{8}$ at $55^{\circ} \mathrm{C}$ at $0.5 \mathrm{C}$-rate $\left(150 \mathrm{~mA} \mathrm{~g}{ }^{-1}\right)$ between 1.8 and $3.8 \mathrm{~V}$. (m) First cycle charge-discharge profiles of various graphite samples at $0.05 \mathrm{C}$ rate. (a-f) Reproduced with permission from Ref. [78]. Copyright 2013, Elsevier. (g, h and $\mathrm{m}$ ) Reproduced with permission from Ref. [84]. Copyright 2012, the Royal Society of Chemistry. (i and j) Reproduced with permission from Ref. [85]. Copyright 2014, Elsevier. (k) Reproduced with permission from Ref. [71]. Copyright 2012, Wiley-VCH. (l) Reproduced with permission from Ref. [83]. Copyright 2013, Elsevier.

Besides, Wang et al. [83] reported that unique $\mathrm{AlF}_{3}$ coated $\mathrm{LiV}_{3} \mathrm{O}_{8}$ nanosheets were synthesized successfully. The $\mathrm{AlF}_{3}$-coated $\mathrm{LiV}_{3} \mathrm{O}_{8}$ showed outstanding cycling stability due to the $\mathrm{AlF}_{3}$ coating layer as well, which could also protect the materials and make it easy for the kinetics of Li-ion diffusion, thus the electrochemical impedance became smaller. The coated one had the capacity retention of $91 \%$ at $150 \mathrm{~mA} \mathrm{~g}^{-1}$ after 50 cycles, much higher than that 
of the bare one, $61 \%$. During cycling, the coated electrode suffered from a capacity loss of $19.1 \%$, while that of the bare one was badly larger $(44.8 \%)$ at $55^{\circ} \mathrm{C}$ (Fig. 31 ).

In addition, the $\mathrm{AlF}_{3}$-coated commercial graphite powders were synthesized successfully for the first time via chemical precipitation by Ding et al. [84]. The 2 wt.\% $\mathrm{AlF}_{3}$-coated graphite particles showed no evident change on the bulk structure, while the thin film was uniform and only $2 \mathrm{~nm}$ thick approximately (Fig. $3 \mathrm{~g}, \mathrm{~h}$ ). The initial discharge capacity of an $\mathrm{AlF}_{3}$-coated graphite anode was much improved in comparison with that of an uncoated one (Fig. $3 \mathrm{~m}$ ). Besides, the $\mathrm{AlF}_{3}$-coated graphite anode delivered a long cycle life than the uncoated one.

Moreover, Li et al. [85] reported that commercial $\mathrm{Li}_{4} \mathrm{Ti}_{5} \mathrm{O}_{12}$ (LTO) could be modified by $\mathrm{AlF}_{3}$ to restrain the gas generation of LTO anode battery effectively. On the one hand, part of $\mathrm{Al}^{3+}$ and $\mathrm{F}^{-}$have been doped into the bulk phase of LTO particles. On the other hand, the remaining $\mathrm{Al}^{3+}$ and $\mathrm{F}^{-}$are still on the surface of the LTO particles for the formation of an $\mathrm{AlF}_{3}$ coating layer (Fig. 3i, j). $\mathrm{AlF}_{3}$ modification is a facile and effective route, which not only can perfect the high-rate charge/discharge performance but also can restrain the gassing behavior of LTO anode battery.

The $\mathrm{AlF}_{3}$ compounds are deemed to be a new material, which have been introduced to investigate the performance of electrode. Surface coating with $\mathrm{AlF}_{3}$ on various cathode materials were tested in LIBs and the results displayed promising electrochemical features.

\section{$\mathrm{AlPO}_{4}$}

Apart from $\mathrm{Al}_{2} \mathrm{O}_{3}$ and $\mathrm{AlF}_{3}, \mathrm{AlPO}_{4}$ is explored as a promising coating material. Cho et al. [86-89] pointed out that the cycling and thermal stability of cathode materials can be enhanced by surface modification with $\mathrm{AlPO}_{4}$. $\left(\mathrm{PO}_{4}\right)^{3-}$ polyanions and $\mathrm{Al}^{3+}$ with high electronegativity, which resist the side reaction with the electrolyte, and oxides with $\left(\mathrm{PO}_{4}\right)^{3-}$ bonding are thermally stable, improving the cycling performance $[88,90]$. Besides, $\mathrm{AlPO}_{4}$ coating acts as a protective layer, reducing the surface exposure of cathode in the electrolyte, thus remitting metal dissolution and reducing oxygen generation [87,89,91-93]. The application of $\mathrm{AlPO}_{4}$ coating involves various kinds of cathode materials, including $\mathrm{LiCoO}_{2}, \mathrm{LiNi}_{0.8} \mathrm{Co}_{0.1} \mathrm{Mn}_{0.1} \mathrm{O}_{2}, \mathrm{LiMn}_{1.5} \mathrm{Ni}_{0.5} \mathrm{O}_{4}$ (Fig. $4 \mathrm{a}-\mathrm{c}$ ), $\mathrm{Li}\left[\mathrm{Li}_{0.2} \mathrm{Ni}_{0.11} \mathrm{Co}_{0.11} \mathrm{Mn}_{0.54} \mathrm{Al}_{0.04}\right] \mathrm{O}_{2}, \quad \mathrm{LiNi}_{0.8} \mathrm{Co}_{0.15} \mathrm{Al}_{0.05} \mathrm{O}_{2}$, $\mathrm{LiV}_{3} \mathrm{O}_{8}, \mathrm{LiMn}_{2} \mathrm{O}_{4}$ and so on $[88,93-100]$. The results have demonstrated the positive effects on the performances. Lately, Wu et al. [101] presented that the layered Li-rich, Fe- and Mn-based cathode materials, $\mathrm{Li}\left[\mathrm{Li}_{0.2} \mathrm{Fe}_{0.1} \mathrm{Ni}_{0.15} \mathrm{Mn}_{0.55}\right] \mathrm{O}_{2}$, were synthesized via a coprecipitation method and modified with $\mathrm{AlPO}_{4}$ subsequently (Fig. 4d). The 5 wt.\% coated sample attracted much attention due to excellent electrochemical performances. Compared to the pristine one, the discharge capacity, cycling, and rate performances were all improved greatly. The sample is able to keep more oxygen ions vacancies, thus improving the discharge capacity. The high electronegativity of $\left(\mathrm{PO}_{4}\right)^{3-}$ polyanions with $\mathrm{Al}^{3+}$ brings about strong resistance to the reaction between bulk material and the electrolyte, then leads to super cycling stability. The enhancement of rate capability is in virtue of the formed $\mathrm{Li}_{3} \mathrm{PO}_{4}$ phase at the surface and the reduction of charge transfer resistance. Due to the great electrochemical property and low cost, the $\mathrm{AlPO}_{4}$ compounds materials show a great promise in designing and modifying Li-rich cathode materials for prospective LIBs.

Several examples of the pristine and $\mathrm{Al}_{2} \mathrm{O}_{3}, \mathrm{AlF}_{3}, \mathrm{AlPO}_{4}$ based electrode materials and their electrochemical performances are given in Table 1.

\section{Al-Si alloy}

Silicon is known as a promising anode material for LIBs because it is inexpensive, abundant in nature and has comparatively low working potential $\left(<0.4 \mathrm{~V} v s . \mathrm{Li} / \mathrm{Li}^{+}\right)$as well as high theoretical capacity [102,103]. Nevertheless, there is large volume change in Si electrodes (4300\%) during $\mathrm{Li}$ insertion/extraction process, which is responsible for the pulverization of electrodes. Meanwhile, it could facilitate the formation of unstable thick SEI layers and accelerate electrolyte depletion, leading to relatively bad capacity fading. Due to these issues, the commercial use of $\mathrm{Si}$ anode materials in LIBs has been severely hindered. One main solution to overcome the defect is to prepare nanostructured Si materials, such as nanoparticles [104], nanowires [105], nanorods [106], NTs [107] and nanocomposites $[108,109]$. In this way, the stress induced by the large volume expansion could be suppressed partly [110]. However, a few important problems have not been solved yet. For example, nano-scaled Si materials are difficult to synthesize; the volumetric energy density is limited; side reaction is aggravated and becomes complicated during the synthetic process; and the cost on production may stay at a relative high level $[110,111]$. Nowadays, people have taken infinite effective measures to improve the electrochemical features of nanostructured Si materials of LIBs. An alternative technique is to develop multinary alloys. Facts proved that $\mathrm{Al}$ seems of great interest as potential 
a

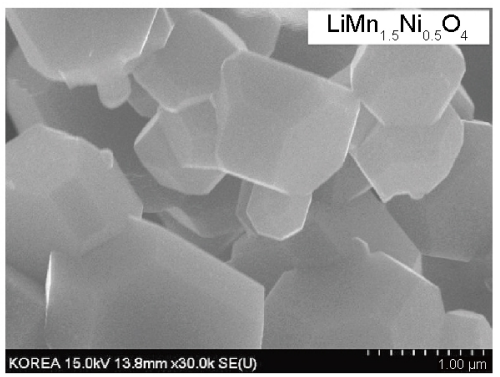

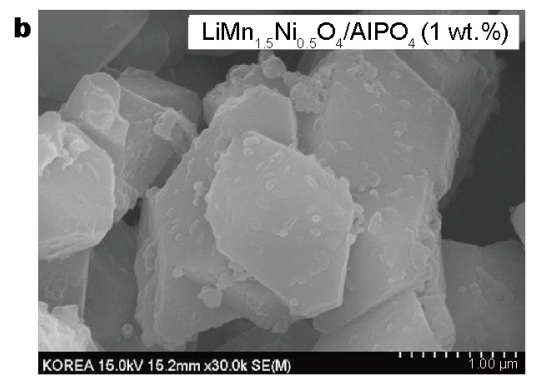

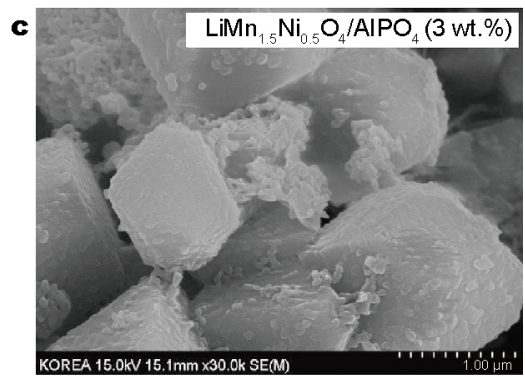

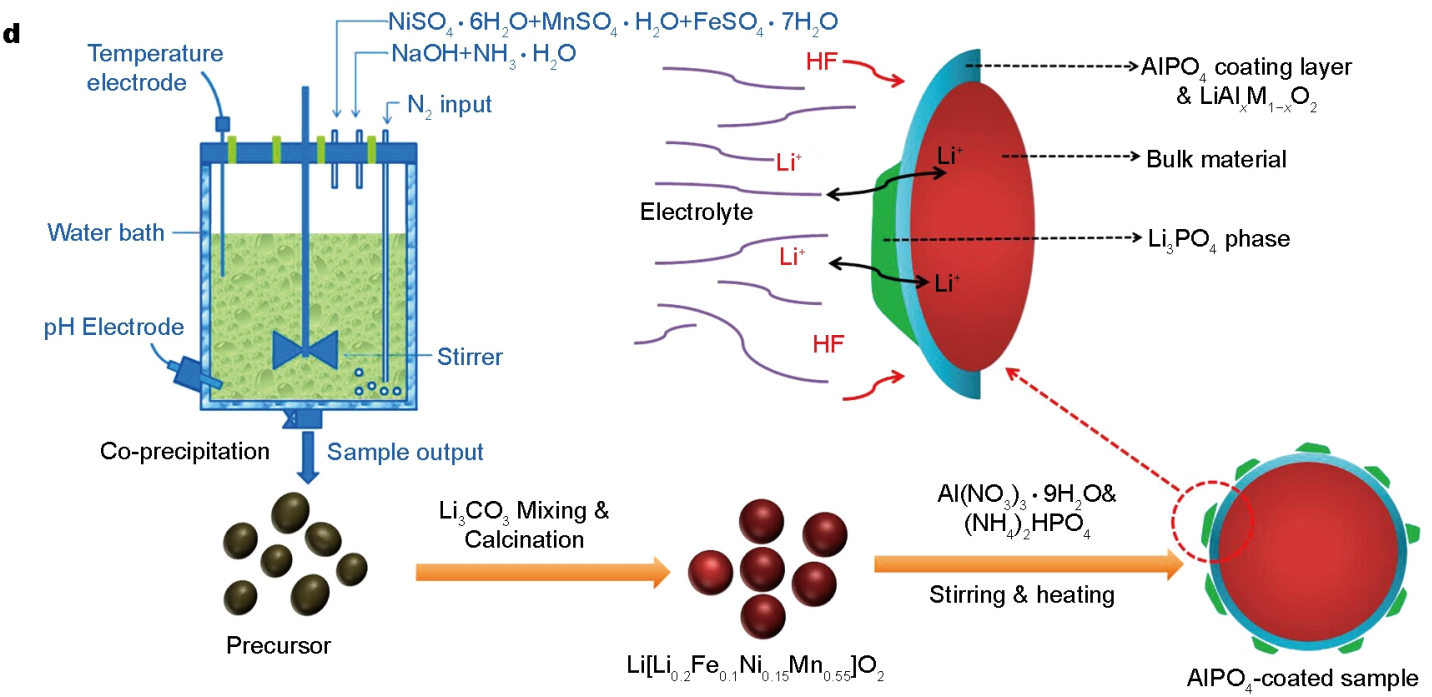

Figure 4 Field emission scanning electron microscopy (FESEM) images of (a) pristine $\mathrm{LiMn}_{1.5} \mathrm{Ni}_{0.5} \mathrm{O}_{4}$, (b) 1 wt.\% $\mathrm{LiMn}_{1.5} \mathrm{Ni}_{0.5} \mathrm{O}_{4} / \mathrm{AlPO}_{4}$, and (c) 3 wt.\% $\mathrm{LiMn}_{1.5} \mathrm{Ni}_{0.5} \mathrm{O}_{4} / \mathrm{AlPO}_{4}$. (d) Schematic illustration of the multifunctional $\mathrm{AlPO}_{4}$ coating synthetic process. (a-c) Reproduced with permission from Ref. [99]. Copyright 2010, Elsevier. (d) Reproduced with permission from Ref. [101]. Copyright 2015, the American Chemical Society.

materials. Here we will illustrate some examples.

First of all, we want to introduce a three dimensional nanostructured multilayer Si/Al film (3D-MSAF) as anode material for LIBs. Si film anodes are good electrical contact to current collector with no need for polymer binders. However, the actual application of Si film anode is limited seriously for the low active material loading [112-114]. Zhang et al. [115] reported a synthesis of 3D-MSAF materials deposited on a 3D nanostructured $\mathrm{Cu}$ current collector via magnetron sputtering method. This Si film in the 3D-MSAF anode with the thickness of $1 \mu \mathrm{m}$, provides enough active material loading. In addition, ductile $\mathrm{Al}$ works as a buffer, placed between Si films to form a multilayer structure for improving the electronic conductivity. The total thickness of $\mathrm{Al}$ film reaches $10 \mathrm{~nm}$ [116-120]. The anode has been tested in LIBs. At current density of $4.2 \mathrm{~A} \mathrm{~g}^{-1}$ or even higher, the reversible capacity is still stable and high, which should be attributed to the nanostructure of the 3D-MSAF, as illustrated schematically in Fig. 5a. The 3D-MSAF could alleviate the volumetric expansion markedly, which is confirmed by the SEM characterization (Fig. 5b, c).

Krishnan et al. [121] proposed a functionally strain-graded carbon-aluminum-silicon (C-Al-Si) architecture anode material that showed superb performance for high power LIBs. Fig. 5d (right) exhibits the schematic diagram of the multilayer nanoscoop. An intermediate layer of aluminum is formed on an amorphous carbon nanorod and a silicon nanoscoop is finally capped on the very top. The gradation of volume change in the three materials with lithium results in the graded levels of strain. Al acting as an intermediate layer plays a significant role in the gradual transition of strain from $\mathrm{C}$ to $\mathrm{Si}$, thus minimizing the incongruity at the interfaces. Therefore, the introduction of Al could keep stable operation of the electrode even under high rate charge/discharge conditions. The anode could provide an average capacity of $\sim 412 \mathrm{~mA} \mathrm{~h} \mathrm{~g}^{-1}$ constantly over 100 charge/discharge cycles at an accelerated current density of $\sim 51.2 \mathrm{~A} \mathrm{~g}^{-1}$ (i.e., charge/discharge rate of $\sim 40 \mathrm{C}$ ). And the capacity retention could be improved 
Table 1 Electrochemical performances of the pristine and $\mathrm{Al}_{2} \mathrm{O}_{3}, \mathrm{AlF}_{3}, \mathrm{AlPO}_{4}$-based nanocomposites

\begin{tabular}{|c|c|c|c|c|c|c|}
\hline Nanocomposites & $\begin{array}{c}\text { Initial } \\
\text { discharge capacity } \\
(\mathrm{mA} \mathrm{h} \mathrm{g})\end{array}$ & $\begin{array}{l}\text { Discharge capacities } \\
\quad\left(\mathrm{mA} \mathrm{h} \mathrm{g}^{-1}\right)\end{array}$ & Cycle & Capacity retention & Temp. & Ref. \\
\hline Pristine $\mathrm{LiMn}_{1.5} \mathrm{Ni}_{0.5} \mathrm{O}_{4}$ & $103.8,0.5 \mathrm{C}$ & 66.8 & 300 & $64.40 \%$ & RT & {$[49]$} \\
\hline 1 at. $\% \mathrm{Al}_{2} \mathrm{O}_{3}$-coated $\mathrm{LiMn}_{1.5} \mathrm{Ni}_{0.5} \mathrm{O}_{4}$ & $101.4,0.5 \mathrm{C}$ & 77.7 & 300 & $76.60 \%$ & RT & {$[49]$} \\
\hline Pristine $\mathrm{LiMn}_{1.5} \mathrm{Ni}_{0.5} \mathrm{O}_{4}$ & $120.8,0.5 \mathrm{C}$ & 27 & 100 & $22.40 \%$ & $55^{\circ} \mathrm{C}$ & {$[49]$} \\
\hline 1 at. $\% \mathrm{Al}_{2} \mathrm{O}_{3}$-coated $\mathrm{LiMn}_{1.5} \mathrm{Ni}_{0.5} \mathrm{O}_{4}$ & $107.7,0.5 \mathrm{C}$ & 84.5 & 100 & $78.50 \%$ & $55^{\circ} \mathrm{C}$ & {$[49]$} \\
\hline Bare $\mathrm{Li}\left(\mathrm{Ni}_{1 / 3} \mathrm{Co}_{1 / 3} \mathrm{Mn}_{1 / 3}\right) \mathrm{O}_{2}$ & $168.4,30 \mathrm{~mA} \mathrm{~g}^{-1}$ & 132.7 & 100 & $78.80 \%$ & RT & {$[51]$} \\
\hline $1 \% \mathrm{Al}_{2} \mathrm{O}_{3}$-modified $\mathrm{Li}\left(\mathrm{Ni}_{1 / 3} \mathrm{Co}_{1 / 3} \mathrm{Mn}_{1 / 3}\right) \mathrm{O}_{2}$ & $170.6,30 \mathrm{~mA} \mathrm{~g}^{-1}$ & 158.6 & 100 & $92.97 \%$ & RT & {$[51]$} \\
\hline Bare $\mathrm{LiMn}_{2} \mathrm{O}_{4}$ & $119.7,20 \mathrm{~mA} \mathrm{~g}^{-1}$ & 68.9 & 25 & $57.56 \%$ & $55^{\circ} \mathrm{C}$ & [39] \\
\hline 2 wt. $\% \mathrm{Al}_{2} \mathrm{O}_{3}$ coated $\mathrm{LiMn}_{2} \mathrm{O}_{4}$ & $118.6,20 \mathrm{~mA} \mathrm{~g}^{-1}$ & 90.2 & 25 & $76.05 \%$ & $55^{\circ} \mathrm{C}$ & {$[39]$} \\
\hline Pristine $\mathrm{LiV}_{3} \mathrm{O}_{8}$ & $309.1,100 \mathrm{~mA} \mathrm{~g}^{-1}$ & 165.4 & 100 & $53.51 \%$ & RT & {$[61]$} \\
\hline 0.5 wt. $\% \mathrm{Al}_{2} \mathrm{O}_{3}$-coated $\mathrm{LiV}_{3} \mathrm{O}_{8}$ & $283.1,100 \mathrm{~mA} \mathrm{~g}^{-1}$ & 205.7 & 100 & $72.66 \%$ & RT & {$[61]$} \\
\hline Pristine $\mathrm{LiV}_{3} \mathrm{O}_{8}$ & $170.6,2000 \mathrm{~mA} \mathrm{~g}^{-1}$ & 91.7 & 100 & $53.80 \%$ & RT & {$[61]$} \\
\hline 0.5 wt. $\% \mathrm{Al}_{2} \mathrm{O}_{3}$-coated $\mathrm{LiV}_{3} \mathrm{O}_{8}$ & $195.5,2000 \mathrm{~mA} \mathrm{~g}^{-1}$ & 139.4 & 100 & $71.30 \%$ & RT & {$[61]$} \\
\hline Pristine $\mathrm{LiV}_{3} \mathrm{O}_{8}$ & $134.2,3000 \mathrm{~mA} \mathrm{~g}^{-1}$ & 74.2 & 100 & $55.30 \%$ & RT & {$[61]$} \\
\hline 0.5 wt. $\% \mathrm{Al}_{2} \mathrm{O}_{3}$-coated $\mathrm{LiV}_{3} \mathrm{O}_{8}$ & $160.2,3000 \mathrm{~mA} \mathrm{~g}^{-1}$ & 118.5 & 100 & $73.97 \%$ & RT & {$[61]$} \\
\hline Pristine $\mathrm{LiMn}_{1.5} \mathrm{Ni}_{0.5} \mathrm{O}_{4}$ & $108.6,14.7 \mathrm{~mA} \mathrm{~g}^{-1}$ & 84.3 & 50 & $77.60 \%$ & - & {$[77]$} \\
\hline 1 wt. $\% \mathrm{AlF}_{3}$-coated $\mathrm{LiMn}_{1.5} \mathrm{Ni}_{0.5} \mathrm{O}_{4}$ & $103.6,14.7 \mathrm{~mA} \mathrm{~g}^{-1}$ & 97 & 50 & $93.60 \%$ & - & {$[77]$} \\
\hline Pristine $\mathrm{Li}_{1.1} \mathrm{Al}_{0.05} \mathrm{Mn}_{1.85} \mathrm{O}_{4}$ & $102,50 \mathrm{~mA} \mathrm{~g}^{-1}$ & 87 & 100 & $85.30 \%$ & $55^{\circ} \mathrm{C}$ & {$[80]$} \\
\hline $\mathrm{AlF}_{3}$-coated $\mathrm{Li}_{1.1} \mathrm{Al}_{0.05} \mathrm{Mn}_{1.85} \mathrm{O}_{4}$ & $106,50 \mathrm{~mA} \mathrm{~g}^{-1}$ & 110.2 & 100 & $96.20 \%$ & $55^{\circ} \mathrm{C}$ & {$[80]$} \\
\hline Pristine $\mathrm{LiMn}_{2} \mathrm{O}_{4}$ & $109.7,148 \mathrm{~mA} \mathrm{~g}^{-1}$ & 78.4 & 100 & $71.40 \%$ & RT & {$[81]$} \\
\hline 2 wt. $\% \mathrm{AlF}_{3}$-coated $\mathrm{LiMn}_{2} \mathrm{O}_{4}$ & $103.4,148 \mathrm{~mA} \mathrm{~g}^{-1}$ & 92.9 & 100 & $89.80 \%$ & RT & {$[81]$} \\
\hline 3 wt. $\% \mathrm{AlF}_{3}$-coated $\mathrm{LiMn}_{2} \mathrm{O}_{4}$ & $99,148 \mathrm{~mA} \mathrm{~g}^{-1}$ & 90.7 & 100 & $91.60 \%$ & RT & {$[81]$} \\
\hline Bare $\mathrm{LiV}_{3} \mathrm{O}_{8}$ & $240.6,150 \mathrm{~mA} \mathrm{~g}^{-1}$ & 146.8 & 50 & $61.01 \%$ & RT & {$[83]$} \\
\hline $\mathrm{AlF}_{3}$-coated $\mathrm{LiV}_{3} \mathrm{O}_{8}$ & $231.5,150 \mathrm{~mA} \mathrm{~g}^{-1}$ & 212.5 & 50 & $91.80 \%$ & RT & {$[83]$} \\
\hline Bare $\mathrm{LiV}_{3} \mathrm{O}_{8}$ & $244.9,150 \mathrm{~mA} \mathrm{~g}^{-1}$ & 135.1 & 40 & $55.20 \%$ & $55^{\circ} \mathrm{C}$ & {$[83]$} \\
\hline $\mathrm{AlF}_{3}$-coated $\mathrm{LiV}_{3} \mathrm{O}_{8}$ & $239.6,150 \mathrm{~mA} \mathrm{~g}^{-1}$ & 193.8 & 40 & $80.90 \%$ & $55^{\circ} \mathrm{C}$ & {$[83]$} \\
\hline $\mathrm{LiMn}_{1.5} \mathrm{Ni}_{0.5} \mathrm{O}_{4}$ & 133 & 115 & 30 & $86.47 \%$ & $55^{\circ} \mathrm{C}$ & [99] \\
\hline 1 wt. $\% \mathrm{AlPO}_{4}$-coated $\mathrm{LiMn}_{1.5} \mathrm{Ni}_{0.5} \mathrm{O}_{4}$ & 130 & 129 & 30 & $99.23 \%$ & $55^{\circ} \mathrm{C}$ & [99] \\
\hline Pristine $\mathrm{Li}\left[\mathrm{Li}_{0.2} \mathrm{Fe}_{0.1} \mathrm{Ni}_{0.15} \mathrm{Mn}_{0.55}\right] \mathrm{O}_{2}$ & $246.2,40 \mathrm{~mA} \mathrm{~g}^{-1}$ & 161.5 & 50 & $65.60 \%$ & - & {$[101]$} \\
\hline $\begin{array}{l}5 \text { wt. } \% \mathrm{AlPO}_{4} \text {-coated } \\
\mathrm{Li}\left[\mathrm{Li}_{0.2} \mathrm{Fe}_{0.1} \mathrm{Ni}_{0.15} \mathrm{Mn}_{0.55}\right] \mathrm{O}_{2}\end{array}$ & $267.2,40 \mathrm{~mA} \mathrm{~g}^{-1}$ & 196 & 50 & $73.35 \%$ & - & {$[101]$} \\
\hline
\end{tabular}

from $\sim 60 \%$ to $\sim 90 \%$ after 100 cycles at $\sim 60 \mathrm{C}$. A comparison of the discharge capacity retention in the C-Al-Si system with a C-Si system indicates that the intermediate Al layer has great effects on improving the electrochemical property (Fig. 5d, e). Clearly, such architecture demonstrates immense feasibility in designing high capacity and high power LIBs.

Zhou et al. [122] reported that unique Al-Si-graphite composites with $7.9 \mathrm{wt} . \%$ Si were successfully prepared via ball-milling eutectic Al-Si powder and graphite. Ex-situ $\mathrm{X}$-ray radiation diffraction (XRD) shows Al-graphite has large volume change during lithium insertion/extraction process, resulting in the issue that the active material is isolated and unavailable for electrochemical reactions. However, the Al-Si-graphite is just an opposite: all the materials in it remain available. The reversible capacity of the Al-Si-graphite is higher than $0.65 \mathrm{~A} \mathrm{~h} \mathrm{~g}^{-1}$ after 10 cycles, equal to $1.6 \mathrm{~A} \mathrm{~h} \mathrm{~cm}^{-3}$, nearly double that of graphite alone.

The two active components ( $\mathrm{Si}$ and $\mathrm{Al}$ ) enable the gradual transition of volume change in electrode on account of their varying lithiation potentials, bringing about stable cycling performance. The electrical conductivity and capacity of electrode can be effectively improved too. In addition, as what mentioned above, the electrochemical property of 
a
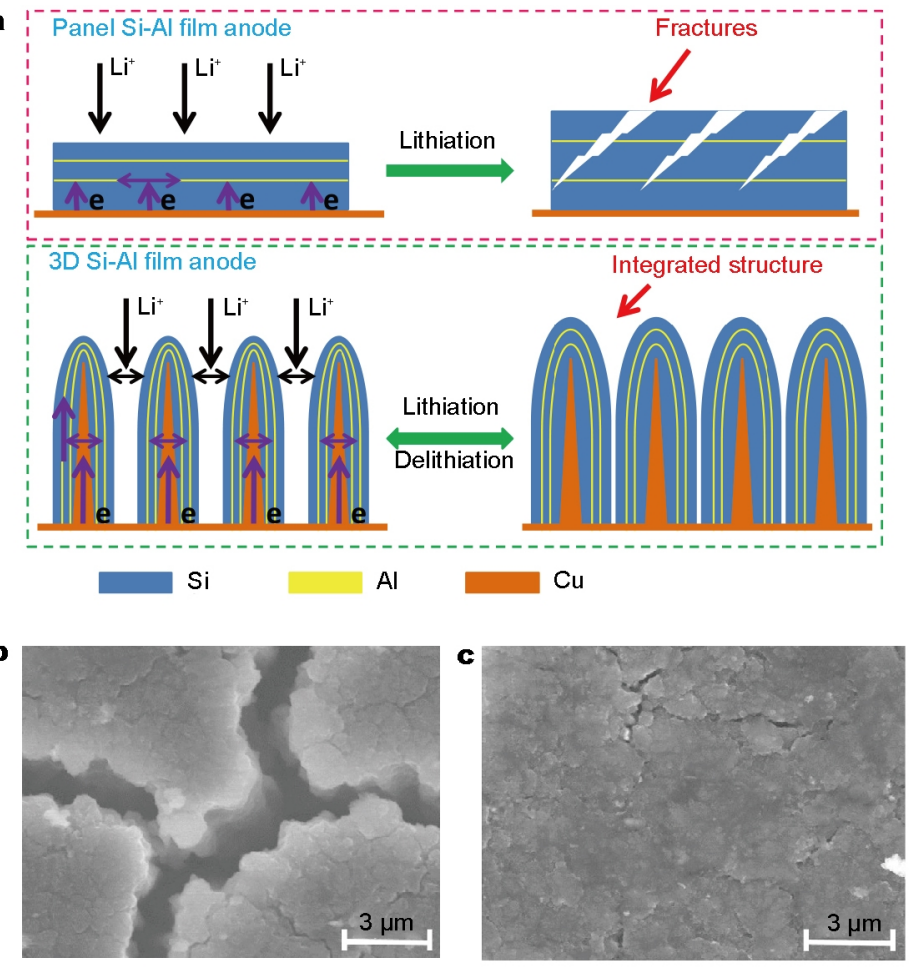

d
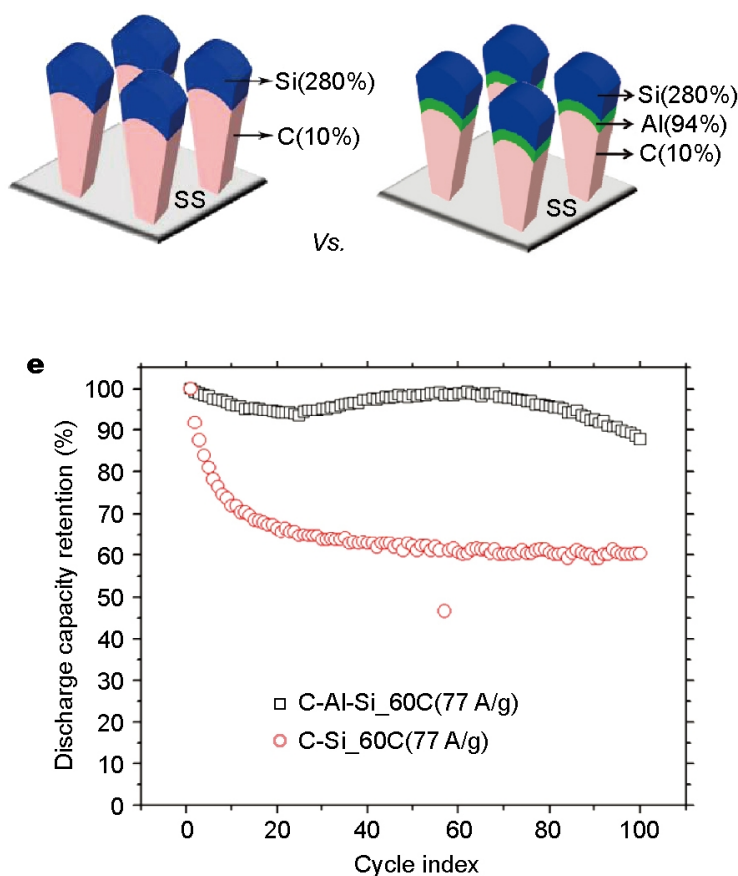

Figure 5 (a) Schematic diagram of the mechanism of 3D-MSAF electrode. SEM images of (b) P-MSAF electrode after 55 cycles and (c) 3D-MSAF electrode after 120 cycles. (d) The right schematic diagram shows the C-Al-Si nanoscoop structure deposited on stainless steel (SS). (e) Discharge capacity retention of C-Si and C-Al-Si structure over 100 cycles. (a-c) Reproduced with permission from Ref. [115]. Copyright 2015, Elsevier. (d and e) Reproduced with permission from Ref. [121]. Copyright 2010, the American Chemical Society.

nanostructured Si material electrode can be enhanced by surface modification of $\mathrm{Al}_{2} \mathrm{O}_{3}, \mathrm{AlF}_{3}, \mathrm{AlPO}_{4}$ and other materials.

\section{$\mathrm{Al}(\mathrm{III})$ doped composites}

To improve electrochemical performance of electrode materials, besides coating with conductive electroactive material on the surface [123-128], doping with metals is also a good method. Metals can not only rise electronic conductivity but deflate polarization as well, therefore the stability of electrode is improved [129-136]. In the past few years, a series of lithium-rich layered cathode materials, with general formula $x \mathrm{Li}_{2} \mathrm{MnO}_{3} \cdot(1-x) \mathrm{LiMO}_{2}$, in which $\mathrm{M}$ is a transition metal or a mixture of transition metals, has attracted extensive attention. However, the family of cathode material has two main defects. First, it delivers a low initial Columbic efficiency and suffers from large irreversible capacity loss during its electrochemical activation at 4.4-4.8 V, which can bring about the change of internal structure. Second, the lithium-rich material has poor rate performance and low discharge voltage plateaus during cycling, especially under high temperature $[137,138]$. Metal ion doping exerts an enormous function on improving the electrochemical performance of these cathode materials [139-141]. Some doped metal ions like $\mathrm{Al}^{3+}$ [142], $\mathrm{Mg}^{2+}$ [143], $\mathrm{Ti}^{4+}$ [144], $\mathrm{Cr}^{3+}$ [145], $\mathrm{Zn}^{2+}$ [146], $\mathrm{Co}^{3+}, \mathrm{Ga}^{3+}, \mathrm{Ti}^{4+}$, etc. [147-152] can facilitate the diffusion of Li ions in the material. Meanwhile, the structure stability can be strengthened due to the reinforced combination of $\mathrm{M}-\mathrm{O}$ bonds in the crystal during cycling. Among these doped elements, $\mathrm{Al}$ has some economic and applied merits [153]. The works using $\mathrm{Al}$ as doping elements proved good achievement.

Yuan et al. [154] synthesized a series of Al-doped $\mathrm{LiAl}_{x} \mathrm{Mn}_{2-x} \mathrm{O}_{4}$ materials by solid-phase grinding reaction at room temperature and calcining at different temperatures for different durations subsequently. Electrochemical experiments demonstrated that the cyclability of the $\mathrm{LiMn}_{2} \mathrm{O}_{4}(\mathrm{LMO})$ spinel doping with an appropriate amount of $\mathrm{Al}$ was better than the pristine LMO in an aqueous media. Besides, Ryu et al. [155] successfully synthesized $\mathrm{LiAl}_{x} \mathrm{Mn}_{2 x} \mathrm{O}_{4}$ nanostructures from Al-doped $\mathrm{MnO}_{2}$ nanorods, nanothorn spheres and spheres. They found that the electrochemical property of LMO was improved by the combined effect of morphological structure and the critical concentration of Al. Wang et al. [156] reported 
3D porous spinel-type lithium manganese oxides were successfully synthesized via a phase-inversion technology utilizing poly(methyl methacrylate) as the template, and annealing under a high temperature subsequently. The as-synthesized $\mathrm{LiAl}_{0.1} \mathrm{Mn}_{1.9} \mathrm{O}_{4}$ (LAMO) was tested and the result showed that doping with $\mathrm{Al}$ could significantly improve the rate capability and cycle performance of the LMO at room temperature. Besides, LAMO displayed an improved cycling capability at $55^{\circ} \mathrm{C}$ as well (Fig. 6a, b). These results suggest that Al-doped LMO could develop into a promising candidate electrode material for LIBs.

A family of Al-substituted spinel $\mathrm{LiNi}_{0.5 x} \mathrm{Al}_{2 x} \mathrm{Mn}_{1.5 x} \mathrm{O}_{4}$ $(0 \leq 2 x \leq 1.0)$ materials were synthesized and the effects of Al concentration on the structural, electrochemical and thermal properties were investigated as well. Not only the hollow structures but also the presence of $\mathrm{Al}$ is thought to have great effects on strengthening crystal structure and
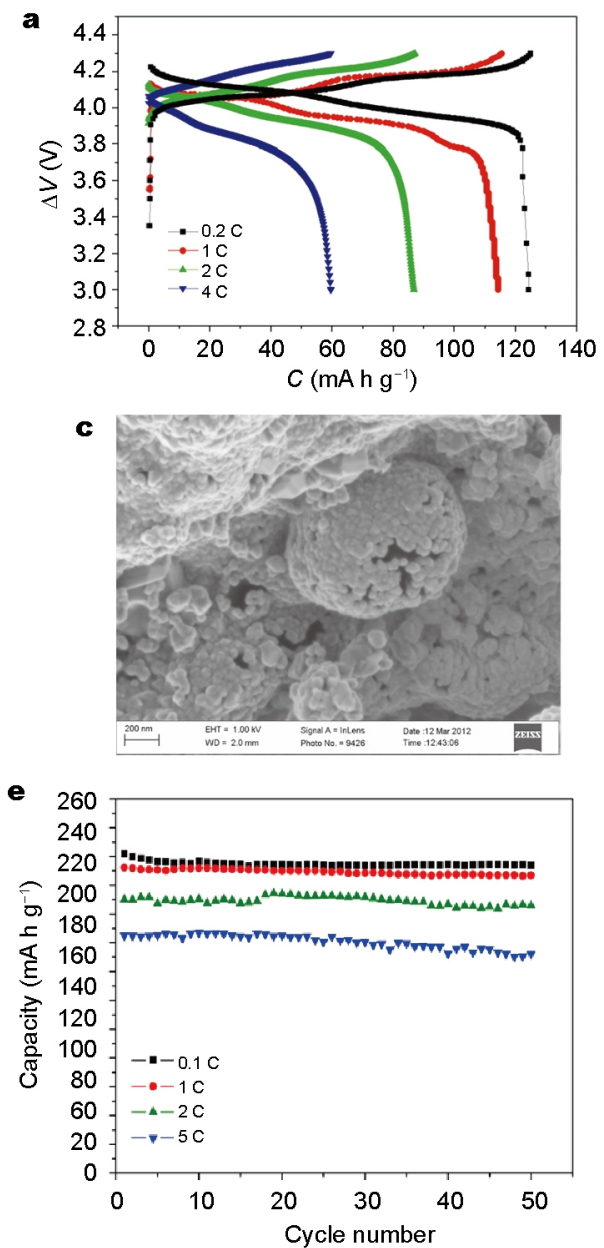

enhancing cycling stability and capacity. For example, Liu et al. [146] presented a simple and cost-effective synthesis of LNMO and Al-doped LNMO hollow microspheres. Compared with the pristine sample, the Al-doped LNMO hollow structures can enhance discharge capacity (up to $\left.140( \pm 5) \mathrm{mA} \mathrm{h} \mathrm{g}^{-1}\right)$ as well as cycling stability (70\% capacity retention after 200 cycles) effectively when acting as high voltage cathode materials. Moreover, $\mathrm{Al}^{3+} \mathrm{can}$ substitute for $\mathrm{Co}^{3+}$, which is relatively toxic and expensive. Herein, the cost of production will be brought down and the materials become more environmentally friendly. Additionally, $\mathrm{Al}^{3+}$ can give the oxygen sheets of the layered structure greater binding energy during the $\mathrm{Li}$ ion removal process, which is propitious to maintain the structure stability as well as improve cycle and rate capabilities of the electrode materials [157]. Jafta et al. [158] found that nanostructured $\mathrm{Li}\left[\mathrm{Li}_{0.2} \mathrm{Mn}_{0.52} \mathrm{Ni}_{0.13} \mathrm{Co}_{0.13} \mathrm{Al}_{0.02}\right] \mathrm{O}_{2}$ (LMNCA) was more orde-
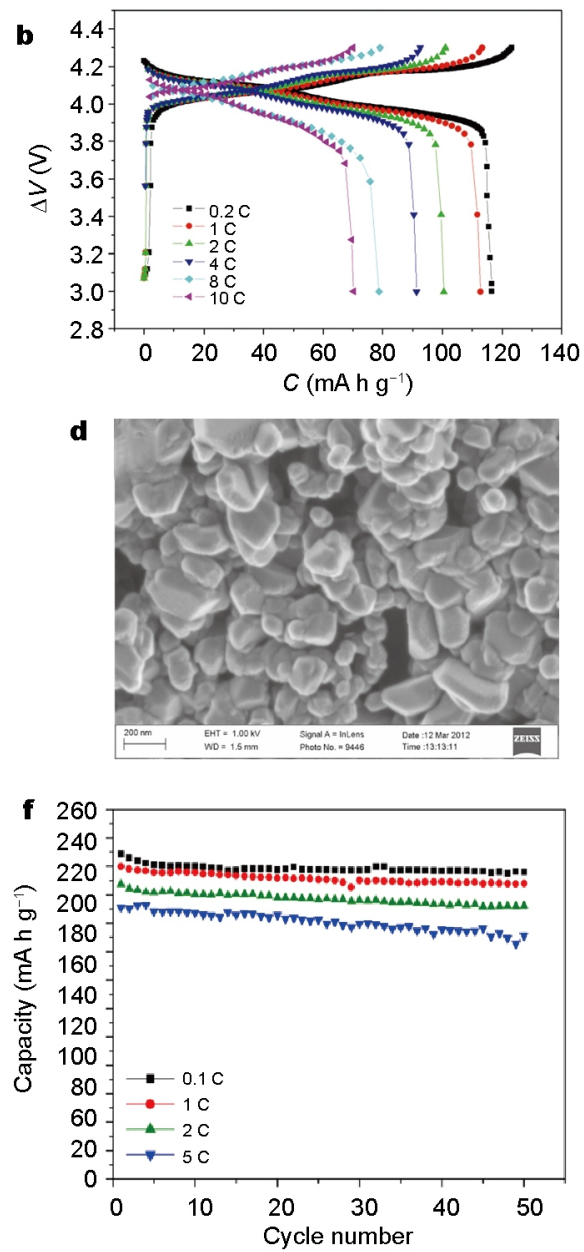

Figure 6 Galvanostatic charge-discharge curves of (a) the pristine $\mathrm{LiMn}_{2} \mathrm{O}_{4}$ and (b) $\mathrm{LiAl}_{0.1} \mathrm{Mn}_{1.9} \mathrm{O}_{4}$ electrodes and their capacity retention ratios. FESEM images of (c) LMNC and (d) LMNCA. Cyclic performance of (e) $\mathrm{Li}_{4} \mathrm{Ti}_{5} \mathrm{O}_{12}$ and (f) $\mathrm{Li}_{4} \mathrm{Ti}_{4.95} \mathrm{Al}_{0.05} \mathrm{O}_{12}$ discharged to 1 V. (a and b) Reproduced with permission from Ref. [156]. Copyright 2012, Elsevier. (c and d) Reproduced with permission from Ref. [158]. Copyright 2012, Elsevier. (e and f) Reproduced with permission from Ref. [160]. Copyright 2012, Elsevier. 
red and crystalline than the $\mathrm{Li}\left[\mathrm{Li}_{0.2} \mathrm{Mn}_{0.54} \mathrm{Ni}_{0.13} \mathrm{Co}_{0.13}\right] \mathrm{O}_{2}$ (LMNC) (Fig. 6c, d). Although the LMNCA delivered a lower initial discharge capacity, it proved better discharge capacity and cycling stability than that of the LMNC. LMNCA also exhibited enhanced electron transfer rate constant and diffusion coefficient in comparison with that of the LMNC. Doping with Al provides more chances to improve the electrochemical property of the LMNC [159].

What's more, spinel lithium titanate and $\mathrm{ZnO}$ nanoparticles have also been chosen to investigate the effect of $\mathrm{Al}^{3+}$ substitution on the microstructure and electrochemical properties of the materials. Lin et al. [160] reported a simple sol-gel process to synthesize spinel $\mathrm{Li}_{4} \mathrm{Ti}_{4.95} \mathrm{Al}_{0.05} \mathrm{O}_{12}$ materials. Compared to $\mathrm{Li}_{4} \mathrm{Ti}_{5} \mathrm{O}_{12}$ electrode, $\mathrm{Li}_{4} \mathrm{Ti}_{4.95} \mathrm{Al}_{0.05} \mathrm{O}_{12}$ electrode has outstanding initial discharge capacity. Meanwhile, the rate capability is improved for the higher $\mathrm{Li}^{+}$ diffusivity and lower charge-transfer resistance because of the substitution of $\mathrm{Al}^{3+}$ for $\mathrm{Ti}^{4+}$. And the cyclic performance of $\mathrm{Li}_{4} \mathrm{Ti}_{4.95} \mathrm{Al}_{0.05} \mathrm{O}_{12}$ electrode is better than that of $\mathrm{Li}_{4} \mathrm{Ti}_{5} \mathrm{O}_{12}$ electrode (Fig. 6e, f) [161] . Zhang et al. [162] revealed unique layered structure of composites were synthesized by anchoring Al-doped $\mathrm{ZnO}$ nanoparticles (AZONs) on the surface of reduced graphene oxide (RGO) sheets based on a facile annealing process. The AZONs/RGO composites have been tested as an LIB anode, the initial charge capacity of which reaches to $624 \mathrm{~mA} \mathrm{~h} \mathrm{~g}^{-1}$. And the composites deliver a $100^{\text {th }}$ charge capacity of $391 \mathrm{~mA} \mathrm{~h} \mathrm{~g}^{-1}$. The AZONs and RGO act synergistically in ways with the unique layered structure, so that the cycling stability and reversible capacity are observably improved too.

All these evidence shows that Al-doped materials can be employed as possible electrode materials for LIBs.

\section{$\mathrm{Al}(\mathrm{OH})_{3}$}

The electrochemical performances of lithium manganesebased oxides can also be improved by mixing with $\mathrm{Al}(\mathrm{OH})_{3}$. $\mathrm{Al}(\mathrm{OH})_{3}$ can adsorb traces of $\mathrm{HF}$ in the electrolyte for forming $\mathrm{AlF}_{3}$, thereby reducing harmful side reactions between cathode and electrolyte, so that the corrosion in active cathode material can be alleviated and the LiF precipitation on the cathode can be suppressed. Hou et al. [163] reported $\mathrm{LiCo}_{1 / 3} \mathrm{Ni}_{1 / 3} \mathrm{Mn}_{1 / 3} \mathrm{O}_{2}$ was synthesized via a facile route mixing with $\mathrm{Al}(\mathrm{OH})_{3}$ additives (Fig. 7a). Commercial 18650 size Li-ion cells was assembled using artificial graphite as anode, $\mathrm{Al}(\mathrm{OH})_{3}$-mixed $\mathrm{LiCo}_{1 / 3} \mathrm{Ni}_{1 / 3} \mathrm{Mn}_{1 / 3} \mathrm{O}_{2}$ as cathode in a $\mathrm{LiPF}_{6}$-based nonaqueous electrolyte. The method has simple operation, thus it can easily realize industrial mass production. $\mathrm{Al}(\mathrm{OH})_{3}$-mixed $\mathrm{LiCo}_{1 / 3} \mathrm{Ni}_{1 / 3} \mathrm{Mn}_{1 / 3} \mathrm{O}_{2}$ material cell shows a capacity retention of $63.1 \%$, much higher than that of the pristine material, $29.7 \%$, between 4.3 and $2.75 \mathrm{~V}$ at
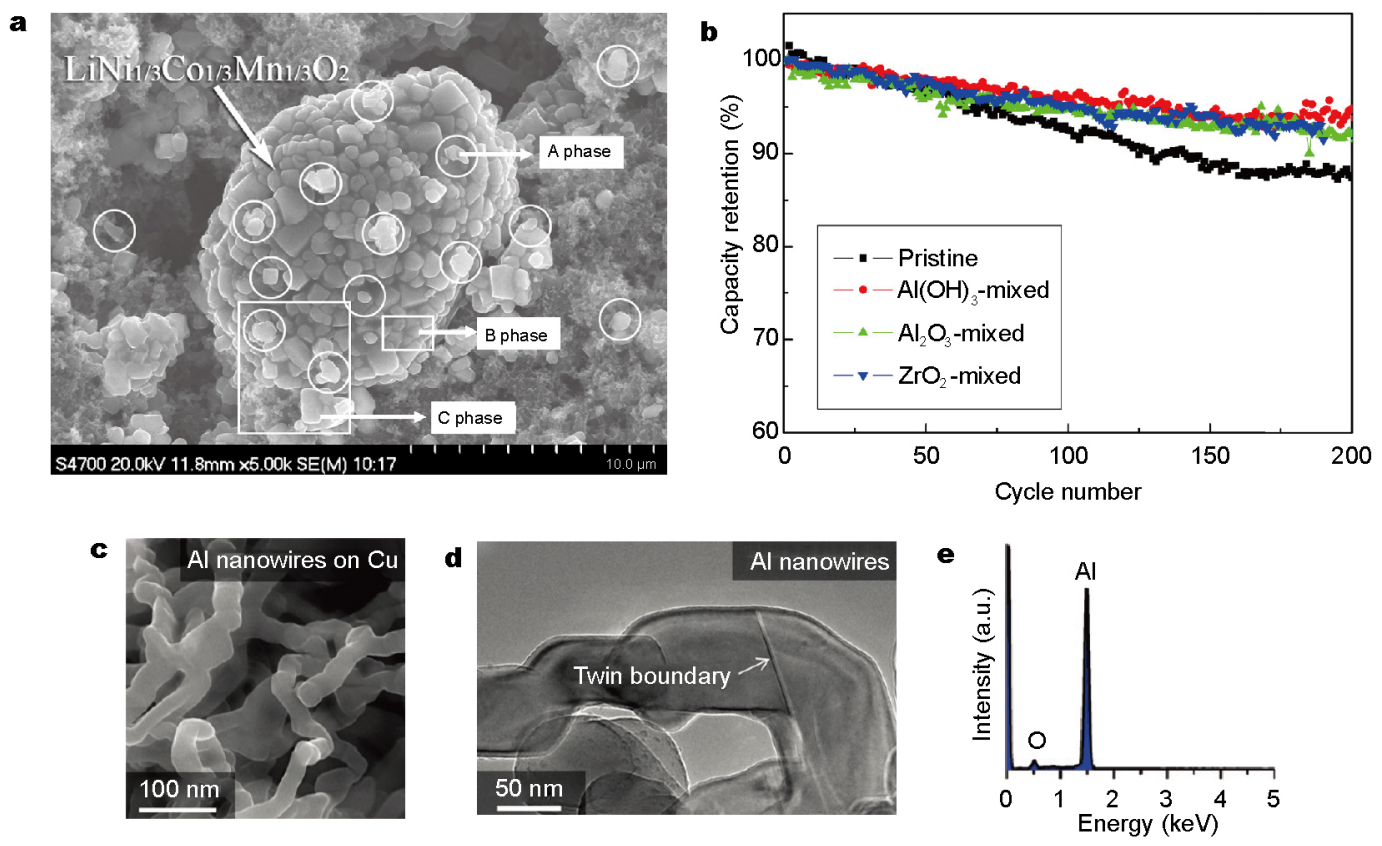

Figure 7 (a) SEM image of $2 \mathrm{wt} . \% \mathrm{Al}(\mathrm{OH})_{3}$-mixed $\mathrm{LiCo}_{1 / 3} \mathrm{Ni}_{1 / 3} \mathrm{Mn}_{1 / 3} \mathrm{O}_{2}$ cathode sheet. The $\mathrm{Al}(\mathrm{OH})_{3}$ particles have been marked with white circles. (b) The cycle performance of the cells without and with additives mixed. (c) High-resolution SEM micrograph showing curved Al NWs produced. (d) TEM micrograph exhibiting a low-resolution image of a twin boundary within an $\mathrm{Al} \mathrm{NW}$ grown on the surface of $\mathrm{Cu}$ at $125^{\circ} \mathrm{C}$. (e) Energy-dispersive spectroscopy (EDS) spectra taken from a single Al NW. (a and b) Reproduced with permission from Ref. [163]. Copyright 2015, Elsevier. (c-e) Reproduced with permission from Ref. [186]. Copyright 2011, the American Chemical Society. 
$55 \mathrm{C}$ after 300 cycles. The cell also has an excellent storage stability compared to the pristine cell (Fig. 7b).

What's more, $\mathrm{Al}(\mathrm{OH})_{3}$-coated spinel materials such as $\mathrm{Li}\left[\mathrm{Ni}_{1 / 3} \mathrm{Co}_{1 / 3} \mathrm{Mn}_{1 / 3}\right] \mathrm{O}_{2}$ [164] and $\mathrm{Li}\left[\mathrm{Li}_{0.2} \mathrm{Ni}_{0.2} \mathrm{Mn}_{0.6}\right] \mathrm{O}_{2}[165]$ also show very good electrochemical properties, which is mainly ascribed to the $\mathrm{Al}(\mathrm{OH})_{3}$ coating because it can suppress the transition metal dissolution and reduce the areaspecific impedance value.

\section{Al NWs}

Fundamental researches about the effects of constrained dimensions on thermal and electrical conductivities in one-dimensional (1D) conductors as well as magnetism of transition metals give a great impetus to earlier researches of metal nanowires (NWs) [166-171]. In the past decade, the size-dependent breakdowns of superconductivity have drawn particular attention in small diameter NWs [166-168]. Nowadays, potential application prospect of metal NWs becomes broader and more attractive, including sensors [172], interconnects [173], ultra-high-density magnetic recording and spintronics [174], transparent current collectors for touch screens and organic solar cells [175], fuel cells [176], current collectors for LIBs [177,178], active anodes for LIBs [179], catalysis [180], hydrogen storage [181], capacitors [182] and supercapacitors [183,184].

$\mathrm{Al}$ has long attracted interest as anode materials for LIBs because of numerous advantages. Various alloying NWs have showed better properties than their bulk counterparts, which has stimulated intense research efforts on preparing Al NWs. The synthesized Al NWs have rather small diameter, providing an easy strain relief path. The electrochemical materials will expand and contract in the reactions of alloying and dealloying. Sometimes, the small diameter of $\mathrm{Al} \mathrm{NWs}$ can strengthen mechanical robustness effectively. Besides, the ion diffusion pathways are shortened in NWs, improving the rate capabilities [185]. Benson et al. [186] demonstrated that patterned Al NWs were successfully deposited onto $\mathrm{Cu}, \mathrm{Ni}$, and SS substrates by decomposing trimethylamine alane complex at low pressure. The obtained Al NWs were crystalline and not mixed up with a detectable amount of carbon impurities, whose average diameter ranged from 45 to $85 \mathrm{~nm}$ (Fig. 7c-e). They have prepared an electrode material for supercapacitor by covering $50 \mathrm{~nm}$ of vanadium oxide on the surface of Al NW via ALD. The volumetric capacitance of the supercapacitor electrodes was very high, which was one order of magnitude higher than that of traditional activated carbon supercapacitor electrodes. However, whether Al NWs can be used in LIBs like some metal NWs still needs further study.

\section{ALUMINUM-ION BATTERYS (AIBS)}

Al has drawn a particular interest as an anode for the Al-air battery due to its overall specific energy and high theoretical ampere-hour capacity [187-191]. However, there are two main drawbacks reducing these values in a practical battery. First, it is extremely difficult to employ $\mathrm{Al}$ and the air cathode at their thermodynamic potentials. Second, the discharge reaction will consume water gradually. In addition, the $\mathrm{Al}$ anode could generate hydrogen inherently in aqueous electrolytes, which has further limited the performance of the battery. Although it has above-mentioned problems, the practical energy density is still very high [192]. People have figured out several feasible solutions such as mechanically replacing the $\mathrm{Al}$ anode after each discharge or adding electrolyte in the battery systems before use. Whereas these adjustments can satisfy some of the limitations, reliable rechargeable $\mathrm{Al} /$ air batteries are still hard to be employed in aqueous electrolytes because they are under the threat of serious corrosion, and hydrogen evolution of $\mathrm{Al}$ is prone to reacting in the electrolyte, resulting in a sharp decrease of anodic efficiency. Moreover, many researches have confirmed the cell efficiency and anodic voltage would be cut down in aqueous media $\mathrm{Al} /$ air battery because an oxide film was covering on the surface of the Al anode [193]. There are a number of studies in the literature aiming to investigate the suitability of ionic liquid-based electrolytes for electrodeposition of Al [194]. In recent years, a new battery technology using an Al-ion conducting ionic liquid as the electrolyte has provided an outlook of the future of AIB in application development.

\section{Ionic liquid-based electrolytes}

An AIB with stable electrochemical property and extended cycle life was first successfully assembled by Jayaprakash et al. [195]. They reported that $\mathrm{Al}^{3+}$ could be reversibly inserted into $\mathrm{V}_{2} \mathrm{O}_{5} \mathrm{NWs}$ in the ionic liquid/ $\mathrm{AlCl}_{3}$ based electrolyte (Fig. 8a, b). The first Al-ion cell showed some promising electrochemical properties (Fig. 8c, d). These features were ascribed to the combined effect of anode, cathode and the electrolyte where the $\mathrm{AlCl}_{3}$ was dissolved in 1-ethyl-3-methylimidazolium chloride ([EMIm]Cl). Particularly, a electrolyte is regarded as a key factor for obtaining high energy density of an AIB. An apposite electrolyte not only possesses great ionic conductivity for $\mathrm{Al}^{3+}$, a wide and stable electrochemical window with the existence of $\mathrm{Al}$, but also can permeate the cathode materials and shows reversible electrochemical deposition and 
$\mathbf{a}$

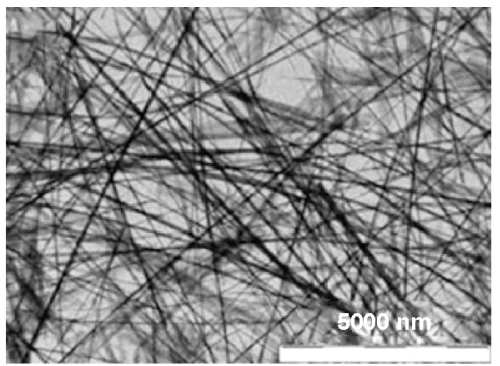

c

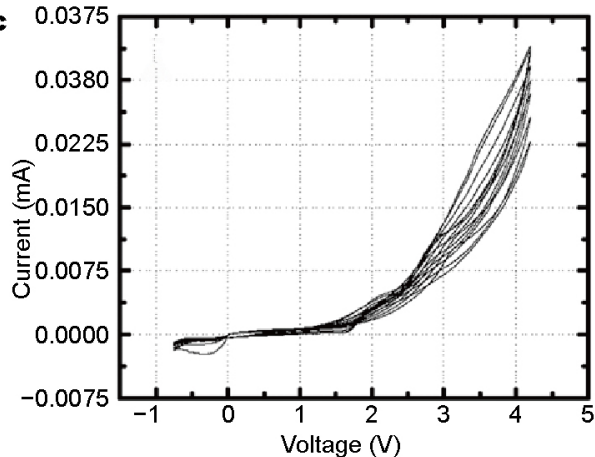

b
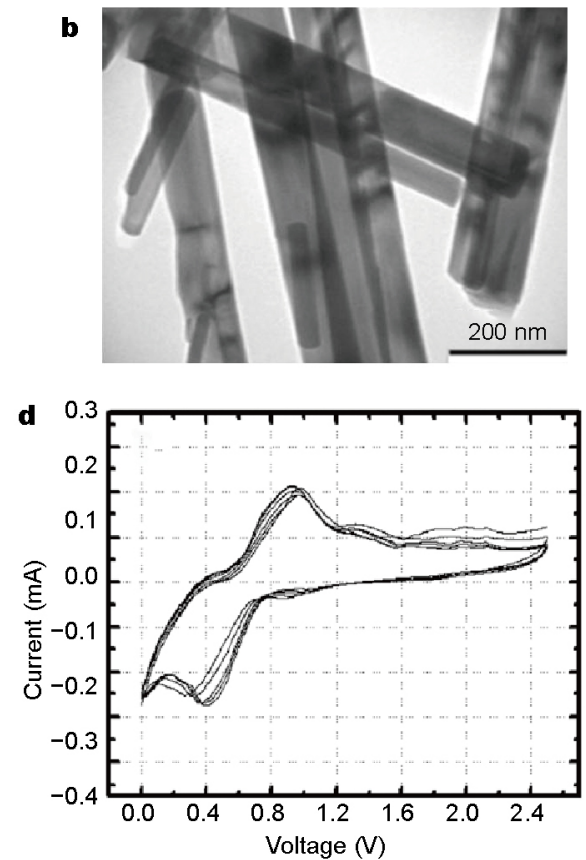

Figure 8 (a) and (b) TEM images of the $\mathrm{V}_{2} \mathrm{O}_{5}$ nanowires as the cathode of AIB. The cyclic voltammograms (CVs) of AIB employing Al anode and $\mathrm{V}_{2} \mathrm{O}_{5} \mathrm{NW}$ cathode in (c) 1:1 v/v of Al triflate in PC/THF and (d) 1:1:1 molar ratio of $\mathrm{AlCl}_{3}$ in ([EMIm]Cl) at a scan rate of $0.2 \mathrm{mV} \mathrm{s}^{-1}$. Reproduced with permission from Ref. [195]. Copyright 2011, the Royal Society of Chemistry.

dissolution of Al. It is very considerable for successful battery technology to choose right electrolyte.

\section{Mixtures of aluminum halides and halide-containing ionic liquids}

AIBs adopting electrolytes containing $\mathrm{Al}$ salts and organic solvents have been studied in recent years. For example, $\mathrm{AlCl}_{3}$-contained imidazole-based ionic liquids are one of the most commonly used electrolytes which displays stable electrochemical behavior. Haloaluminate anions are thought to play a significant role in electrochemical performance of these electrolytes, so that they affect the performance of an AIB. In this respect, Wang et al. [196] first demonstrated the effect brought by anions. They found anions had great effects on the conductivity of ionic liquids and the electrochemical window, mainly reflecting in the following two aspects. First, aluminum chloride anions $\left(\mathrm{Cl}^{-} \rightarrow \mathrm{AlCl}_{4}{ }^{-} \rightarrow \mathrm{Al}_{2} \mathrm{Cl}_{7}^{-}\right)$caused by various $\mathrm{AlCl}_{3} /$ imidazole salt mole ratios are the determining factor of the electrochemical activities. Second, the halogen anions $\left(\mathrm{AlCl}_{4}^{-} \rightarrow \mathrm{AlCl}_{3} \mathrm{Br}^{-} \rightarrow \mathrm{AlCl}_{3} \mathrm{I}^{-}\right)$caused by various halogenated imidazole salt species exert a critical function on the electrochemical windows.

Halide-free electrolyte

$\mathrm{AlCl}_{3}$-contained imidazole-based ionic liquids possess much superiority; however, they are corrosive, moisture sensitive, and have low oxidation voltage. In order to further develop AIBs, Wang et al. [197] additionally put forward a new strategy. They mixed 1-butyl-3-methylimidazolium trifluoromethanesulfonate ([BMIM]OTF) with the corresponding aluminum salt $\left(\mathrm{Al}(\mathrm{OTF})_{3}\right)$ to prepare a water-stable and noncorrosive ionic liquid. On this basis, a corrosive $\mathrm{AlCl}_{3}$-based electrolyte is used to create a route for $\mathrm{Al}^{3+}$ on the $\mathrm{Al}$ anode and the as-prepared ionic liquid is devoted to obtain stable $\mathrm{Al} /$ electrolyte interface subsequently. Experiments show that the ionic liquid electrolyte possesses excellent ionic conductivity and a high oxidation voltage, exhibiting a great promise in advanced battery systems.

\section{Polymer gel electrolyte}

Besides, the polymer gel electrolyte was first prepared by free radical polymerization. It used acidic ionic liquid containing $[\mathrm{EMIm}] \mathrm{Cl}$ and $\mathrm{AlCl}_{3}\left([\mathrm{EMIm}] \mathrm{Cl}: \mathrm{AlCl}_{3}\right.$, 1:1.5, in molar ratio) as a plasticizer and $\mathrm{AlCl}_{3}$ complexed acrylamide as a functional monomer [198]. The electrochemical deposition and dissolution of $\mathrm{Al}$ in a polymer gel electrolyte with $80 \mathrm{wt}$.\% ionic liquid not only can realize $\mathrm{Al}$ deposition with less moisture sensitivity but also allow AIB to be more flexible in cell configuration. These polymer gel electrolytes are considered as another excellent candidate 
for advanced AIBs (Fig. 9a).

These studies are expected to give guidance in selecting and designing suitable electrolytes for rechargeable AIBs.

\section{Cathode materials}

For LIBs, there is reversible $\mathrm{Li}$ ions insertion/extraction in
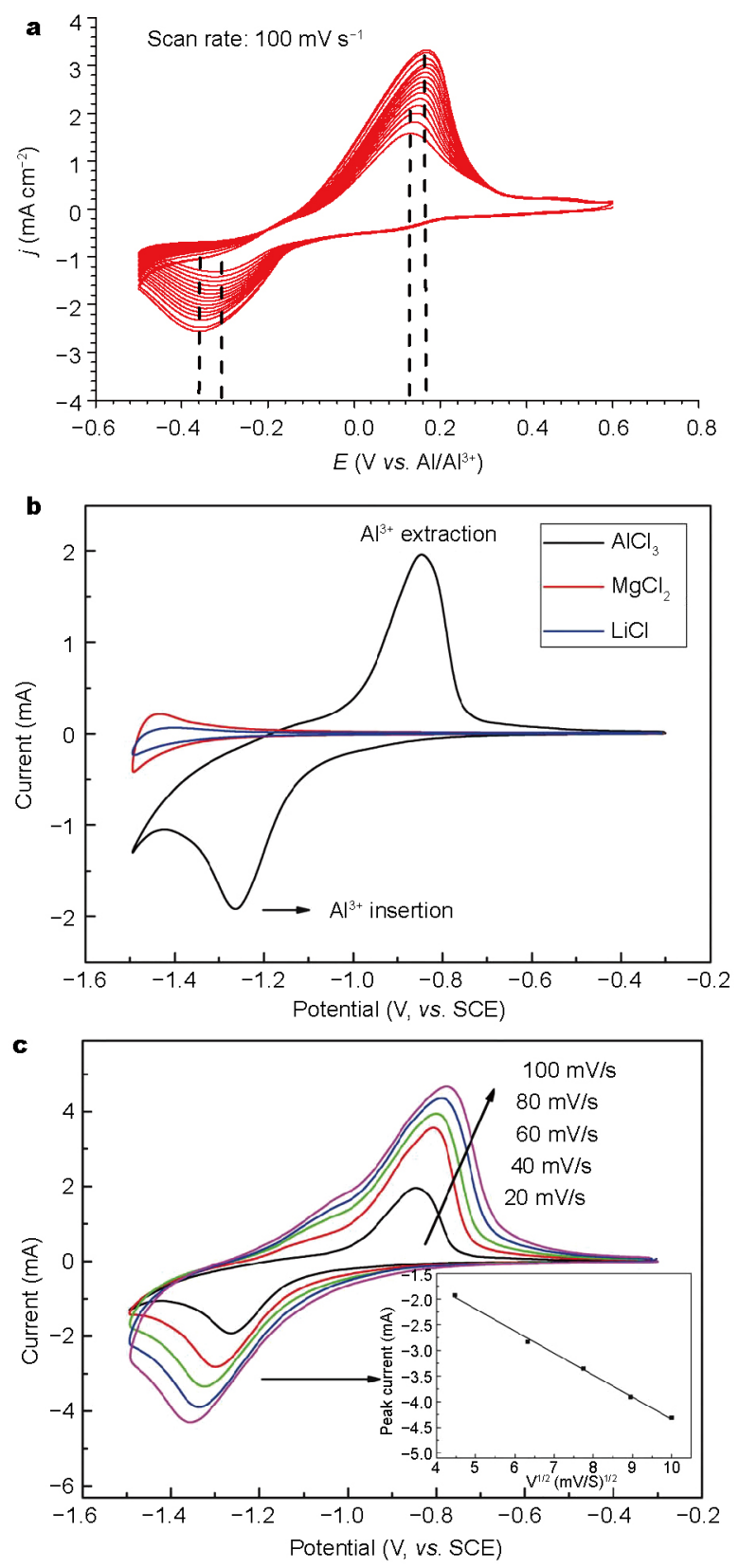

the electroactive materials with a charge transfer. It is reported that the size of guest ions is a considerable factor for the feasibility of the intercalation reaction and the ion mobility. Large ions could suffer from both energetic and steric trap, along with the difficulty of ion mobility. The radius of $\mathrm{Al}^{3+}$ cation $(53.5 \mathrm{pm})$ is smaller than that of $\mathrm{Li}^{+}$ d

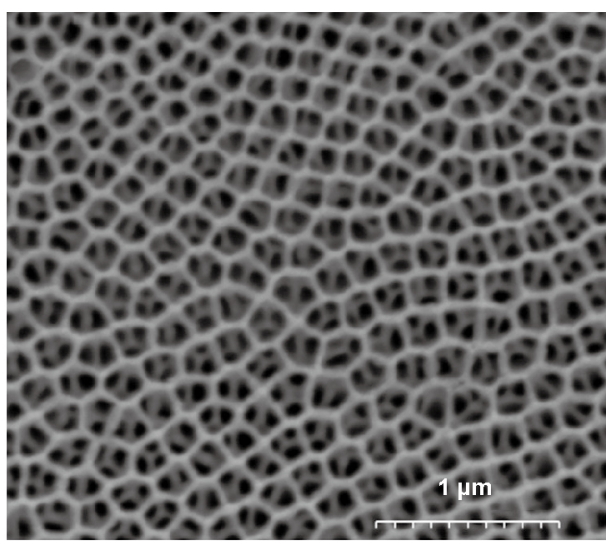

e

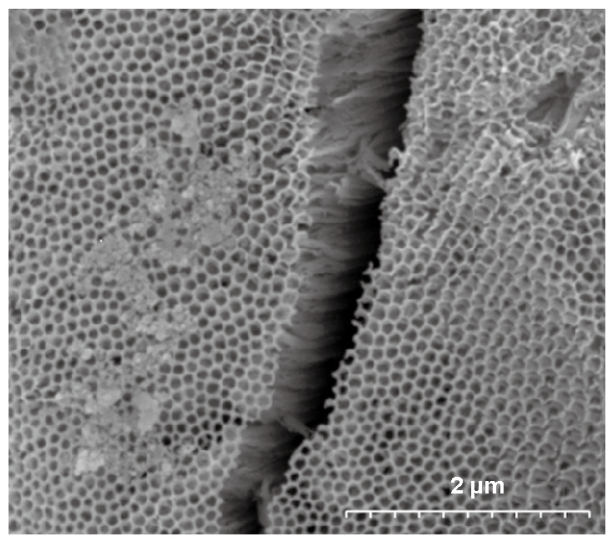

$\mathbf{f}$

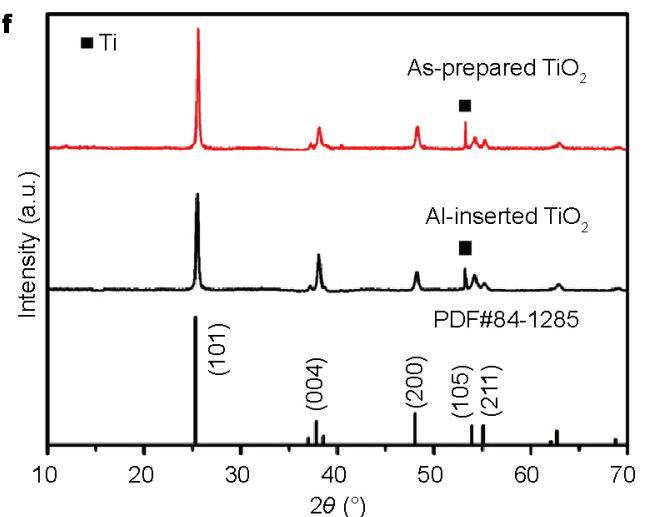

Figure 9 (a) CVs of the polymer gel electrolyte with $60 \mathrm{wt} . \%$ of EMImCl- $\mathrm{AlCl}_{3}$ at $50^{\circ} \mathrm{C}$ at a scan rate of $100 \mathrm{mV} \mathrm{s}^{-1}$.(b) $\mathrm{CVs}_{\text {s }}$ of the anatase $\mathrm{TiO}_{2}-\mathrm{NTA}^{-}$ in $1 \mathrm{~mol} \mathrm{~L}^{-1} \mathrm{AlCl}_{3}, \mathrm{MgCl}_{2}$ and $\mathrm{LiCl}$ aqueous solutions at $20 \mathrm{mV} \mathrm{s}{ }^{-1}$ and (c) CVs in $1 \mathrm{~mol} \mathrm{~L}^{-1} \mathrm{AlCl}_{3}$ aqueous solution at various scan rates. Inset, the relationship between the cathodic peak currents and scan rates. (d) Top view and (e) side view of FESEM images of the Al-inserted TiO ${ }_{2}$-NTA films. (f) XRD patterns of the as-synthesized $\mathrm{TiO}_{2}$ and Al-inserted $\mathrm{TiO}_{2}-\mathrm{NTA}$ film. (a) Reproduced with permission from Ref. [198]. Copyright 2016, the Royal Society of Chemistry. (b and c) Reproduced with permission from Ref. [206]. Copyright 2012, the Royal Society of Chemistry. (d-f) Reproduced with permission from Ref. [207]. Copyright 2014, Elsevier. 
cation $(76 \mathrm{pm})$. Hence, $\mathrm{Al}^{3+}$ cation shows a great promise in intercalation chemistry. And recently Gu et al. [199] first provided clear evidence that $\mathrm{Al}^{3+}$ inserted into the metal oxide and stored reversibly was possible.

The research of AIBs is in beginning stage now, since some potential issues need to solve. These problems are all chronic and fundamental, mainly coming from the fact that it is difficult to find suitable cathode materials which let simple ion transfer in a reversible way. These problems include slow ion transport, poor cycle life, the decomposition of cathode materials, and low discharge voltage profiles with unclear plateaus [187,195,200-204].

The first Al-ion cell was mentioned above, which adopted $\mathrm{Al}$ metal as the anode and $\mathrm{V}_{2} \mathrm{O}_{5}$ as the cathode, showing very stable electrochemical behaviour. It has a theoretical energy density of $240 \mathrm{~W} \mathrm{~h} \mathrm{~kg}{ }^{-1}$. Although the energy density is not very high, it is sufficient to undertake a global search for new materials for the other noticeable characteristics.

\section{$\mathrm{TiO}_{2}$ nanotube arrays}

In the last few years, people have the expectation that $\mathrm{Al}^{3+}$ cations could intercalate in the anatase $\mathrm{TiO}_{2}$ electrochemically in aqueous electrolytes. Anatase $\mathrm{TiO}_{2}$ is a nontoxic material and has good chemical stability. It has been widely applied in many aspects already. One of the most noteworthy applications of the material is the electrochemical Li storage with a stable host structure in aqueous electrolytes [205]. Besides, $\mathrm{TiO}_{2} \mathrm{NT}$ arrays $\left(\mathrm{TiO}_{2}\right.$-NTAs) can be a fast diffusion path for electrolyte species and guarantee good contact between electrode and electrolyte, which are mainly ascribed to the unique nanosized geometry and large surface area. Liu et al. [206] first initiated investigation in regard to the feasibility of the electrochemical $\mathrm{Al}$ storage of anatase $\mathrm{TiO}_{2}$ - $\mathrm{NTA}$ in $\mathrm{AlCl}_{3}$ aqueous solution to explore aqueous AIBs. As the experiments displayed, $\mathrm{Al}^{3+}$ were able to be inserted into and extracted from the $\mathrm{TiO}_{2}-\mathrm{NTA}$ reversibly owing to the small radius of $\mathrm{Al}^{3+}$, thus the $\mathrm{TiO}_{2}$-NTA showed excellent electrochemical features as a cathode material for AIBs. In the preliminary research, the capacity of $\mathrm{TiO}_{2}-\mathrm{NTA}$ was tested to be $\sim 75 \mathrm{~mA} \mathrm{~h} \mathrm{~g}^{-1}$ at 4 $\mathrm{mA} \mathrm{cm}{ }^{-2}$ in $\mathrm{AlCl}_{3}$ aqueous electrolyte. The result indicates a possible application of multi-valent ions with the small radius as guest species in intercalation chemistry (Fig. 9b, c).

In order to further promote the feasibility of AIBs in aqueous electrolyte solution, Liu et al. [207] made deeper investigation to enhance the electrochemical property. They reported that the $\mathrm{TiO}_{2}$-NTAs were synthesized via a two-step anodic oxidation process, followed by annealing at $450^{\circ} \mathrm{C}$. By polarizing the $\mathrm{TiO}_{2}-\mathrm{NTAs}$ electrode at $0.4 \mathrm{~mA}$ for $2 \mathrm{~min}$ in $1 \mathrm{~mol} \mathrm{~L}^{-1} \mathrm{AlCl}_{3}$, the Al-inserted $\mathrm{TiO}_{2}$-NTAs was obtained. Compared to the pristine one, the Al-inserted sample exhibited no change on NT array morphology, remaining the pure anatase $\mathrm{TiO}_{2}$ phase (Fig. 9d, e). X-ray photoelectron spectroscopy (XPS) was used to evaluate the composition and structure of the samples too. The results demonstrated the insertion of $\mathrm{Al}^{3+}$ into $\mathrm{TiO}_{2}$-NTAs helped the reduction of $\mathrm{Ti}^{4+}$ to $\mathrm{Ti}^{3+}$ (Fig. 9f). What's more, they also found the existence of $\mathrm{Cl}^{-}$exerted an enormous function on valid insertion $\mathrm{Al}^{3+}$ into or extraction $\mathrm{Al}^{3+}$ from the $\mathrm{TiO}_{2}$-NTAs. To sum up, anatase $\mathrm{TiO}_{2}$-NTA is reported to show some promise as new electrode material for AIB due to its stability and reversibility in aluminum insertion/extraction process in aqueous electrolyte solution. However, $\mathrm{TiO}_{2} \mathrm{NTs}$, which have many advantages, deliver a relatively low specific capacity.

\section{Graphitic materials}

Lin et al. [208] recently presented that a rechargeable AIB was constituted with a cathode of 3D graphitic foam (3DGF), a anode of an $\mathrm{Al}$ metal and a non-flammable ionic liquid as electrolyte, which had high-rate capability (Fig. 10a). The battery showed clear discharge voltage plateaus near $2 \mathrm{~V}$, a specific capacity of approximately $70 \mathrm{~mA} \mathrm{~h} \mathrm{~g}^{-1}$ and a Coulombic efficiency of about $98 \%$. Besides, they discovered that the cathode could accelerate the diffusion and intercalation of anion, thus enabling to afford a charge time of about $1 \mathrm{~min}$ at a current density of $4000 \mathrm{~mA} \mathrm{~g}^{-1}$ (i.e., $3000 \mathrm{~W} \mathrm{~kg}^{-1}$ ). Meanwhile, it showed no capacity decay after 7500 cycles (Fig. 10b). Wu et al. [209] reported an advanced 3DGF was prepared through intercalation of chloroaluminate anion in the graphite and thermal expansion along with electrochemical hydrogen evolution in the pores of graphitic sheets occurred subsequently. The method prevented a lot of irreversible oxidation of graphite and avoided introduction of extensive oxidation-induced defects into the graphene sheets. The 3DGF is able to orient vertically aligned graphene perpendicular to a current collector substrate. Owing to the interesting feature, it can help electrochemical reactions. A uniform vertically aligned graphitic structure enables a cathode in an AIB to show a discharge capacity of $\sim 60 \mathrm{~mA} \mathrm{~h} \mathrm{~g}^{-1}$ steadily at a high current density of $12,000 \mathrm{~mA} \mathrm{~g}^{-1}$ after 4000 cycles.

Herein, the selection of carbon as the cathode material plays a significant role in assembling ultrafast performance AIBs. However, the rate capabilities of natural graphite and pyrolytic graphite are poor, the specific capacity are low at 

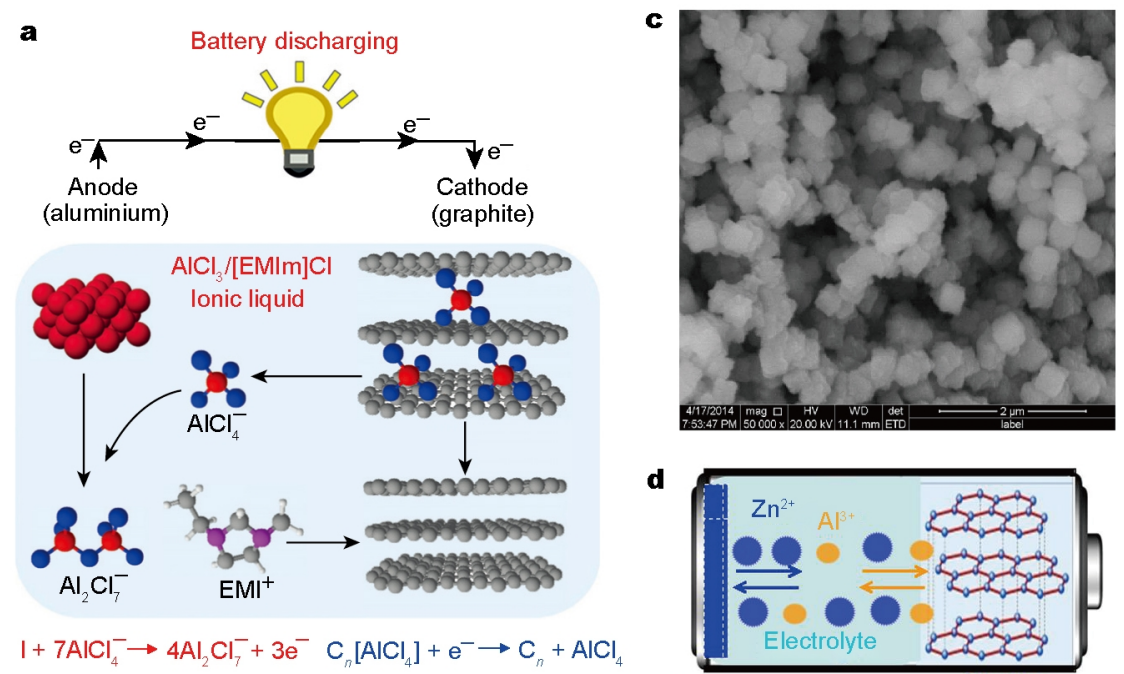

b
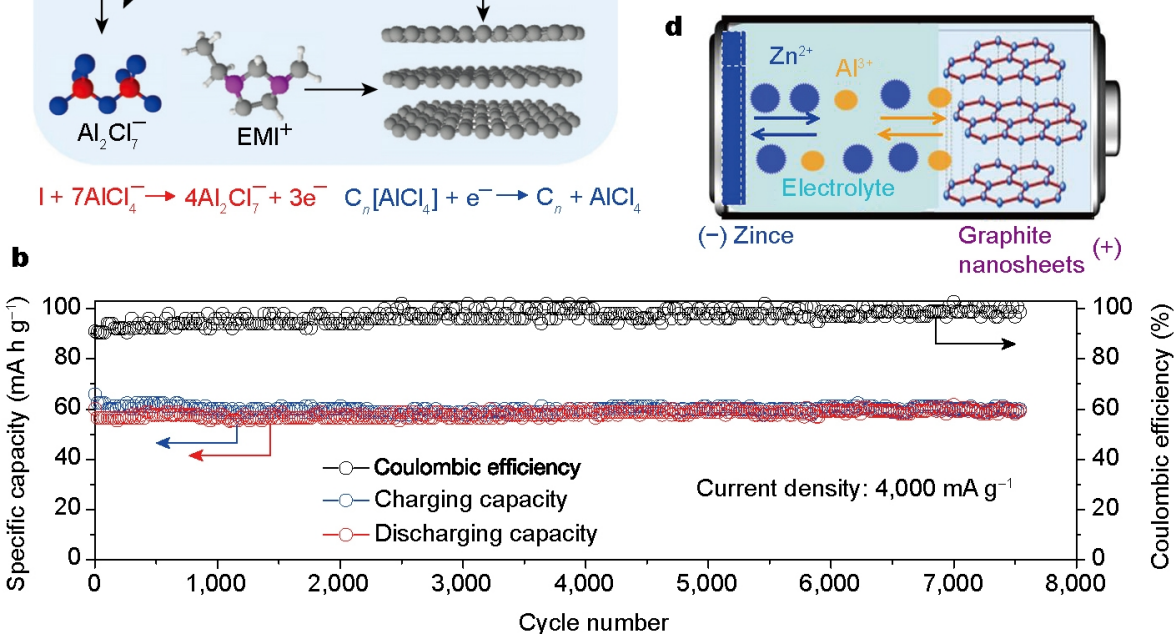

Figure 10 (a) Schematic diagram of the Al/graphite cell during discharge. (b) The stability test of an Al/graphitic-foam pouch cell over 7500 chargedischarge cycles. (c) SEM image of the binder-free Ni- $\mathrm{V}_{2} \mathrm{O}_{5}$. (d) Schematic diagram of the redox reactions in $\mathrm{Zn} / /$ Graphite nanosheet aqueous battery. (a and b) Reproduced with permission from Ref. [208]. Copyright 2015, Macmillan Publishers Limited. (c) Reproduced with permission from Ref. [213]. Copyright 2014, the American Chemical Society. (d) Reproduced with permission from Ref. [214]. Copyright 2015, the American Chemical Society.

the given current densities. The 3D graphene foam and graphite have such advantages, but the charge cutoff voltage is $2.45 \mathrm{~V}$ when used as cathode in an AIB. The charge cutoff voltage is a little higher than the decomposition voltage of the electrolyte, aggravating the side reactions in the charge process, resulting in a capacity of merely about 60 $\mathrm{mA} \mathrm{h} \mathrm{g}{ }^{-1}$. Consequently, it is considerable to reduce the cutoff charge voltage as well as enhance the capacity for a novel AIBs [210]. To solve this problem, Yu et al. [211] for the first time, reported plasma-etching graphene nanoribbons on highly porous 3D graphene (GNHPG) foam as a cathode material for rechargeable AIBs (Fig. 11). The cutoff charge voltage of the flexibility and freestanding pouch cell is $2.3 \mathrm{~V}$, which is lower than the electrolyte decomposition voltage, disenabling side reactions during the charge process. And the discharge voltage plateau is high close to $2 \mathrm{~V}$. The cell shows a high capacity about $123 \mathrm{~mA} \mathrm{~h} \mathrm{~g}^{-1}$ at a current density of $5000 \mathrm{~mA} \mathrm{~g}^{-1}$ with Coulombic efficiency in excess of $98 \%$. There is no capacity decay even after more than 10,000 cycles and the rate performance are up to 148 ,
$125,123,119,116$, and $111 \mathrm{~mA} \mathrm{~h} \mathrm{~g}^{-1}$ at current densities of 2000, 4000, 5000, 6000, 7000, and $8000 \mathrm{~m} \mathrm{~A} \mathrm{~g}^{-1}$, respectively. What's more, the battery can be fully charged in 80 $\mathrm{s}$ and discharged for more than $3100 \mathrm{~s}$. It is also rather remarkable that no matter what the current temperature (up to 40,60 , and $80^{\circ} \mathrm{C}$ or at $0^{\circ} \mathrm{C}$ ), the AIB still shows excellent electrochemical performance. In summary, superior electrochemical properties are shown not only in the capacity, Coulombic efficiency, cycle life, and rate capability, but also in the fast charge together with slow discharge, and thermal stability.

Besides, Jung et al. [212] have conducted an investigation about the structure, energetics, mechanical property and ionic conductivity of $\mathrm{AlCl}_{4}{ }^{-}$inserted graphitic materials by adopting the first-principles calculation. They found the fully charged graphitic cathode in AIBs was at stage 3, which had doubly stacked intercalation structure. The diffusivity of $\mathrm{AlCl}_{4}^{-}$in few layer graphene films tends to be worse with the number of graphene layer decreasing below 5. Particularly, few-layered graphene has low elastic stiff- 

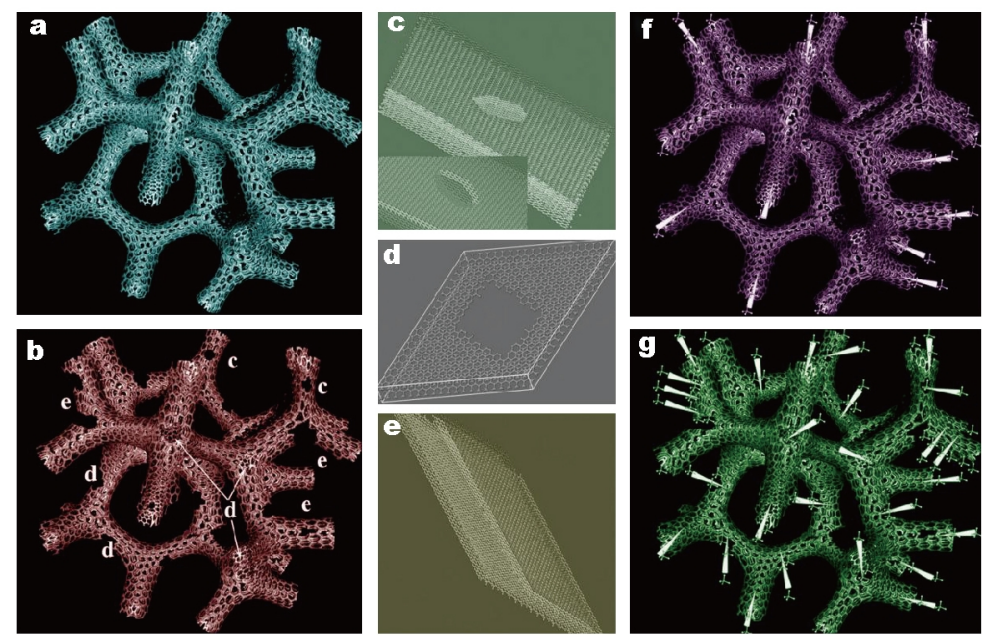

Figure 11 Schematic diagram of (a) 3D graphene and (b) nanoribbon formation on the surface of highly porous 3D graphene, (c) nanopore formation on graphene, (d) pore of graphene, and (e) graphene nanoribbon formation on the graphene. Schematic illustration of (f) $\mathrm{AlCl}_{4}^{-}$anions insertion/extraction in the 3D graphene foam and (g) nanoribbons on highly porous 3D graphene foam. Reproduced with permission from Ref. [211]. Copyright 2016, Wiley-VCH.

ness, providing more free space for $\mathrm{AlCl}_{4}{ }^{-}$diffusion, which is considered as the origin of the ultrafast rate performance of graphitic foam. Graphite is deemed as a promising electrode material for the AIBs in an $\mathrm{AlCl}_{3} /$ ionic liquid electrolyte. These studies represent a milestone for the development of rechargeable AIBs.

Binder-free $\mathrm{V}_{2} \mathrm{O}_{5}$

Wang et al. [213] reoprted that a binder-free cathode material was prepared via directly depositing $\mathrm{V}_{2} \mathrm{O}_{5}$ on a Ni foam current collector (Fig. 10c). A rechargeable aluminum coin cell that used the binder-free $\mathrm{V}_{2} \mathrm{O}_{5}$ cathode had a much higher initial discharge capacity $\left(239 \mathrm{~mA} \mathrm{~h} \mathrm{~g}^{-1}\right)$ than the cell that used a cathode material with $\mathrm{V}_{2} \mathrm{O}_{5}$ nanowires and binder. The discharge voltage plateau is slightly higher as well due to the reduction of electrochemical polarization.

\section{Others}

In addition to these studies, Wang et al. [214] demonstrated that graphite nanosheets with an expanded interlayer distance were successfully synthesized via a facile electrochemically expanded approach. Then, a new aqueous battery was fabricated using $\mathrm{Zn}$ as cathode, the graphite nanosheet as anode and aqueous $\mathrm{Al}_{2}\left(\mathrm{SO}_{4}\right)_{3} / \mathrm{Zn}(\mathrm{CHCOO})_{2}$ solution as electrolyte (Fig. 10d). The new aqueous battery has many advantages in electrochemical properties. First, the cycling stability is excellent (nearly $94 \%$ capacity retention after 200 cycles). Second, this aqueous rechargeable battery has a high average working voltage $(1 \mathrm{~V})$ in an ionic liquid electrolyte. Third, it could be fully charged in 2 min and retain a high capacity. Last but not least, the raw materials are abundant and the aqueous electrolyte with the $\mathrm{Zn}$ cathode is cheap. This battery is attractive for good electrochemical properties as well as low cost and offers new opportunities for the application in large-scale stationary energy storage.

\section{MICRO/NANOSTRUCTURED Al-BASED MATERIALS FOR NICKEL-METAL HYDRIDE BATTERY}

Layered double hydroxides (LDH), a class of materials belonging to the natural anionic clay family, noted as $\mathrm{M}^{2+}{ }_{1-x} \mathrm{M}^{3+}{ }_{x} \mathrm{~A}_{x / n}{ }^{n-}(\mathrm{OH})_{2} \cdot y \mathrm{H}_{2} \mathrm{O} \quad\left(\mathrm{A}^{n-}=\mathrm{OH}^{-}, \quad \mathrm{CO}_{3}{ }^{2-}, \quad \mathrm{NO}_{3}{ }^{-}\right)$, are believed to have potential applications spreading over many fields. As a point of clarification, a net positive charge will appear in natural anionic clays when a certain fraction $x$ of the divalent and trivalent cations are substituted. Excess positive charge can make up for anions which are involved in the interslabs $[215,216]$. On account of the capacity for anions intercalation and exchange, LDH materials play a role in catalysis [217], magnetics [218,219], precursors to oxides [220], anion exchangers [221,222], and electrodes for rechargeable alkaline battery [223-225]. The representative cathode materials for alkaline battery include nickel hydroxide. It has been divided into two kinds. While one is $\alpha-\mathrm{Ni}(\mathrm{OH})_{2}$, the other is $\beta-\mathrm{Ni}(\mathrm{OH})_{2}$. They will respectively turn into $\gamma-\mathrm{NiOOH}$ and $\beta$-NiOOH after fully charged [226]. In general, the capacity of $\alpha-\mathrm{Ni}(\mathrm{OH})_{2}$ is more reversible than that of $\beta-\mathrm{Ni}(\mathrm{OH})_{2}$, mainly ascribed to the higher average oxidation state of nickel. It is noted that the $\gamma-\mathrm{NiOOH}$ transformed from 
$\alpha-\mathrm{Ni}(\mathrm{OH})_{2}$ reveals a higher oxidation value of 3.67 , compared with the $\beta-\mathrm{NiOOH}$ (an oxidation value of 3) [227]. Nonetheless, the stability of $\alpha-\mathrm{Ni}(\mathrm{OH})_{2}$ is poor, which easily transforms into $\beta-\mathrm{Ni}(\mathrm{OH})_{2}$ in the synthesis process. Besides, strong alkaline media can also lead to the same results. These facts bring about rapid capacity decay to the electrode [228]. Under the circumstances, nickel-based LDHs are suggested to be the electrode materials for alkaline secondary battery in order to increase configurational stability of $\alpha-\mathrm{Ni}(\mathrm{OH})_{2}$. The $\mathrm{Ni}^{2+}$ in $\mathrm{Ni}(\mathrm{OH})_{2}$ host layer are partly substituted by metal ion like $\mathrm{Al}^{3+}[229-232], \mathrm{Co}^{3+}$ $[233,234], \mathrm{Fe}^{3+}[235,236], \mathrm{Zn}^{2+}[237,238], \mathrm{Mn}^{3+}[236,239]$, or $\mathrm{Y}^{3+}[240]$, in the nickel-based LDHs. Among these fungible metal ion, $\mathrm{Al}^{3+}$ is thought to be the best candidate for its good electrochemical suitability [230]. Several investigations confirm that the Al-substituted $\alpha-\mathrm{Ni}(\mathrm{OH})_{2}$ (also known as nickel aluminum layered double hydroxide (Ni-Al LDH)) not only shows better cycle stability but also delivers a higher discharge capacity than $\alpha-\mathrm{Ni}(\mathrm{OH})_{2}$ [241-243].

$\mathrm{Hu}$ et al. [244] prepared a $\left[\mathrm{Ni}_{4} \mathrm{Al}(\mathrm{OH})_{10}\right] \mathrm{OH}$ electrode, which could be fully charged within $12 \mathrm{~min}$ and deliver a good capacity. But this Al substitution strategy suffers from the following two problems. First, the relative atomic mass of $\mathrm{Al}$ element is much smaller than that of $\mathrm{Ni}$, leading to a great decline of tap-density as the increase of $\mathrm{Al}$ amount. Although the ionic radiuses of the two elements are different, it does not change the result. Second, $\mathrm{Al}$ is inefficient in the electrochemical redox reaction, so that the increase in the $\mathrm{Al}$ amount also can result in a discharge capacity fade [245]. Besides, it is quite difficult to achieve $\mathrm{Al}$ contained metal particles coprecipitation with high density and large size [246]. For instance, Chen [245] has come up with a complexation-coprecipitation approach for the synthesis of spherical Ni-Al LDH samples. Even the highest tap-density is merely $1.1 \mathrm{~g} \mathrm{~cm}^{-3}$, which is inferior to spherical $\beta-\mathrm{Ni}(\mathrm{OH})_{2}[243]$. Besides, LDHs is enslaved to inherent electrical conductivity directly, which give rise to serious polarization in alkaline rechargeable batteries during high-rate charge/discharge cycling. This problem must be noticed as well $[247,248]$.

\section{Nickel-aluminum layered double hydroxide/carbon (Ni-Al $\mathrm{LDH} / \mathrm{C}$ )}

Béléké et al. [249-252] demonstrated a novel synthetic method to prepare $\mathrm{Ni}-\mathrm{Al} \mathrm{LDH} / \mathrm{C}$ for the applications in battery systems, which was called liquid phase deposition (LPD) [253-257]. Unlike traditional LPD process, this approach used $\mathrm{Al}\left(\mathrm{NO}_{3}\right)_{3}$ as a raw material directly to receive
$\mathrm{Ni}-\mathrm{Al} \mathrm{LDH}$ and a fluoride scavenger. The reaction equation is described as follows.

$\mathrm{Al}\left(\mathrm{NO}_{3}\right)_{3}+6 \mathrm{HF}=\mathrm{H}_{3} \mathrm{AlF}_{6}+3 \mathrm{HNO}_{3}$

The LPD method has some benefits. On the one hand, the amount of substituted $\mathrm{Al}^{3+}$ in the $\mathrm{Ni}(\mathrm{OH})_{2}$ lattices and the films deposited on carbon particles is feasibly controlled. On the other hand, the synthetic products have high crystallinity and pure phase. And the method does not need to adjust the $\mathrm{pH}$ value.

The features of LPD-prepared Ni-Al LDH/C were evaluated through a variety of ways. The results showed not only the $\mathrm{LDH}$ content but also the $\mathrm{Al}^{3+} /\left(\mathrm{Al}^{3+}+\mathrm{Ni}^{2+}\right)$ (Al ratio) was important to the electrochemical property of the $\mathrm{Ni}-\mathrm{Al}$ LDH/C electrode (Fig. 12a-c). The discharge capacity of the optimal composition is $393 \mathrm{~mA} \mathrm{~h} \mathrm{~g}^{-1}$ comp at $1.0 \mathrm{C}$-rate. That is to say, each $\mathrm{Ni}$ atom can exchange 1.35 electrons. The capacity retention of the electrode is also very good. In addition, a superb electrochemical stability is achieved after 300 charge-discharge cycles (Fig. 12d, e). It is easy to see that the Ni-Al LDH/C composites show a great promise in the application of prospective Ni-MH secondary battery.

\section{Nickel-aluminum layered double hydroxide-graphene (Ni-Al LDH-graphene)}

Graphene, a flat sheet of carbon just one atom thick, has attracted extensive attention in electrochemical energy storage. Graphene is an excellent conductive enhancer owing to its extremely high intrinsic electrical conductivity. Gao et al. [258] reported that $\mathrm{Ni}-\mathrm{Al} \mathrm{LDH}$ could be grown on the graphene sheets directly based on a hydrothermal process. The as-prepared Ni-Al LDH-graphene composites showed splendid capacitive property. Zhang et al. [259] demonstrated that a Ni-Al LDH-graphene was successfully synthesized via in situ LPD of LDH sheets on GO. The composite also showed outstanding capacitive property. Obviously, it is feasible for the Ni-Al LDH-graphene to be supercapacitor electrode materials, which is mainly attributed to the conducting networks of graphene. The magical networks can facilitate the redox rate on LDH surface, thereby satisfying the supercapacitor power demand [260]. In spite of that, it is difficult for $\mathrm{Ni}$ - $\mathrm{Al} \mathrm{LDH-graphene} \mathrm{to} \mathrm{be} \mathrm{electrode}$ materials in high-rate battery through deposition growth strategies. Because just the outmost layer next to graphene sheets can capture/deliver the electrons from/to the conducting graphene base rapidly, however, the other layers in the multilayered LDH composites do not have the capability to support high-rate energy.

$\mathrm{Hu}$ et al. [261] presented a synthetic method of $\mathrm{Ni}-\mathrm{Al}$ LDH-graphene superlattice composites, as illustrated sche- 

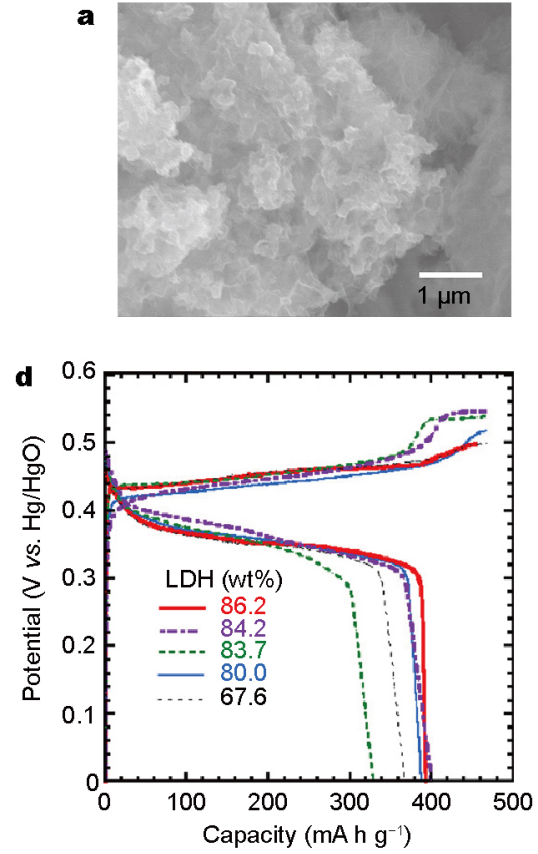

b
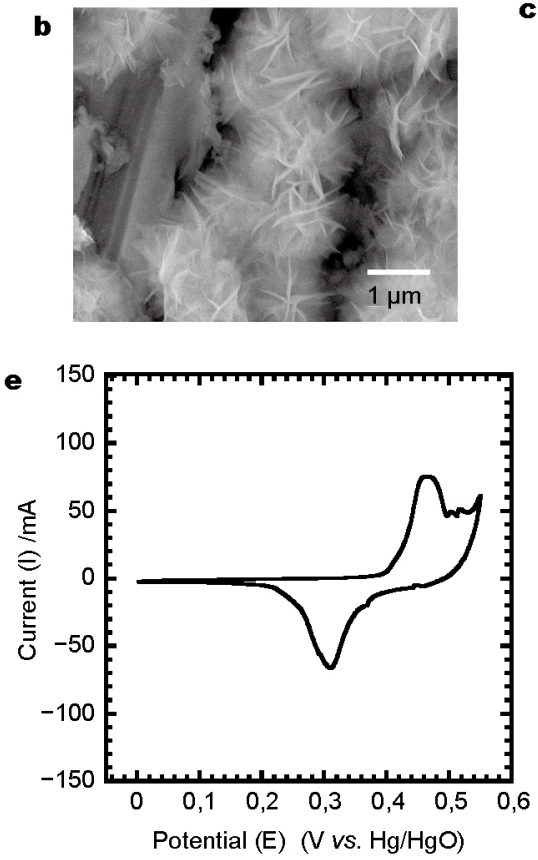

c

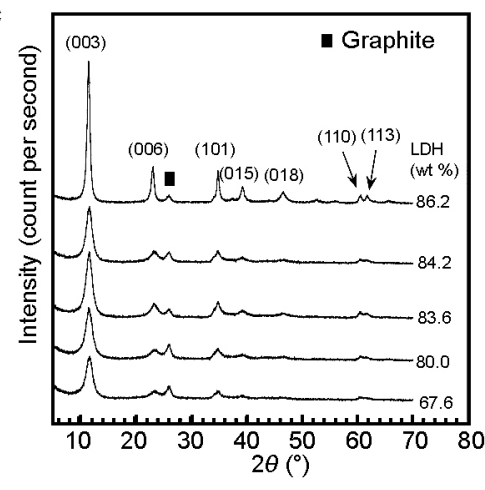

$f$

(1)

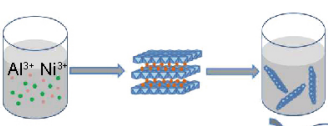

(2)

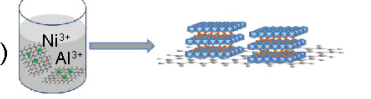

Figure 12 The top view SEM image of Ni-Al LDH/C (a) 67.2 wt.\% LDH contents, (b) 86 wt.\% LDH contents. (c) XRD patterns of Ni-Al LDH/C with different LDH contents. (d) Fifteenth charge-discharge curves of cathodes containing different LDH contents at 1.0 C-rate (2 mA). (e) Typical CV of the electrode with $19.2 \% \mathrm{Al}^{3+}$ and $86.2 \mathrm{wt} . \% \mathrm{LDH}$ at $1 \mathrm{mV} \mathrm{s}^{-1}$. (f) Schematic illustration of the construction for Ni-Al LDH-graphene composite. (1) Superlattice obtained by alternating assembly, (2) hybrid via deposition growth. (a-e) Reproduced with permission from Ref. [250]. Copyright 2012, Elsevier. (f) Reproduced with permission from Ref. [261]. Copyright 2015, the Royal Society of Chemistry.

matically in Fig. 12f. Compared with the pristine Ni-Al $\mathrm{LDH}$, the composite is observed without an obvious change on bulk structure. However, the intercalated graphene shows a wider interlayered gap (Fig. 13a-c). And there is always a graphene layer between every two LDH block layers. The superlattice structure activates all the $\mathrm{Ni}-\mathrm{Al} \mathrm{LDH}$ layers via neighboring graphene conducting networks, leading to the improvement in the electrochemical performance of LDH materials, especially in quick charge-transfer reactions. The Ni-Al LDH-graphene superlattice composites electrode can take full advantage of the conductivity of graphene and maximal layers of the LDH, maintaining steady cycle life and exhibiting a superior capacity at a high current density (Fig. 13d-f). Therefore, the composite is regarded as a suitable cathode material for a high-rate battery.

\section{Cobalt-aluminum layered double hydroxide (Co-Al-LDH)}

$\mathrm{Hu}$ et al. [244] showed an interest in incorporating $\mathrm{Co}^{2+}$ into the crystal lattice of $\mathrm{Ni}-\mathrm{Al} \mathrm{LDH}$, because of the comparatively similar size of $\mathrm{Co}^{2+}$ and $\mathrm{Ni}^{2+}$. It is probable for $\mathrm{Co}^{2+}$ to form LDHs with $\mathrm{Al}^{3+}$ which possess a semblable construction to Ni-Al LDH [262]. The coprecipitation of $\mathrm{Co}^{2+}$ is proved to be effective to improve the cycle life and charge efficiency of $\mathrm{Ni}-\mathrm{Al} \mathrm{LDH}$. Divalent $\mathrm{Co}^{2+}$ will be oxidized into trivalent $\mathrm{Co}^{3+}$ which is insoluble in the alkaline solution. The $\mathrm{Co}^{3+}$ ions exert the function of $\mathrm{Al}^{3+}$ ions on increasing structural stability of $\mathrm{Ni}-\mathrm{Al} \mathrm{LDH}$ materials [263]. Depth research on the effects of cobalt in Ni-Al LDH materials have been carried on, including the morphology, structure and electrochemical property. $\mathrm{Ni}_{4-x} \mathrm{Co}_{x} \mathrm{Al}$ LDHs ( $x$ is $0,0.8,1.0,2.0,3.0,3.2$ and 4.0 ) were successfully synthesized via the homogeneous coprecipitation and the hydrolysis of urea. The electrochemical property of $\mathrm{Ni}$-Al LDH can be enhanced by substituting an appropriate amount of cobalt for nickel, since cobalt can improve the electrode conductivity and reduce the charge transfer resistance. Electrochemical characterizations also exhibit that precipitating $\mathrm{Co}_{4} \mathrm{Al} \mathrm{LDH}$ on the surface of $\mathrm{Ni}_{4} \mathrm{Al} \mathrm{LDH}$ is optimal (Fig. 14a, b). As far as they are concerned, surface precipitation of $\mathrm{Co}_{4} \mathrm{Al} \mathrm{LDH}$ shows a more even distribution on $\mathrm{Ni}_{4} \mathrm{Al} \mathrm{LDH}$, resulting in improved electric conductivity and availability.

Feng et al. [264] presented that the Co-Al-LDH was successfully prepared via hydrothermal synthesis method and they tested the electrochemical property of the Co-Al-LDH as an additive for the nickel electrode in Ni-MH secondary battery. They came up with the same result about the best 

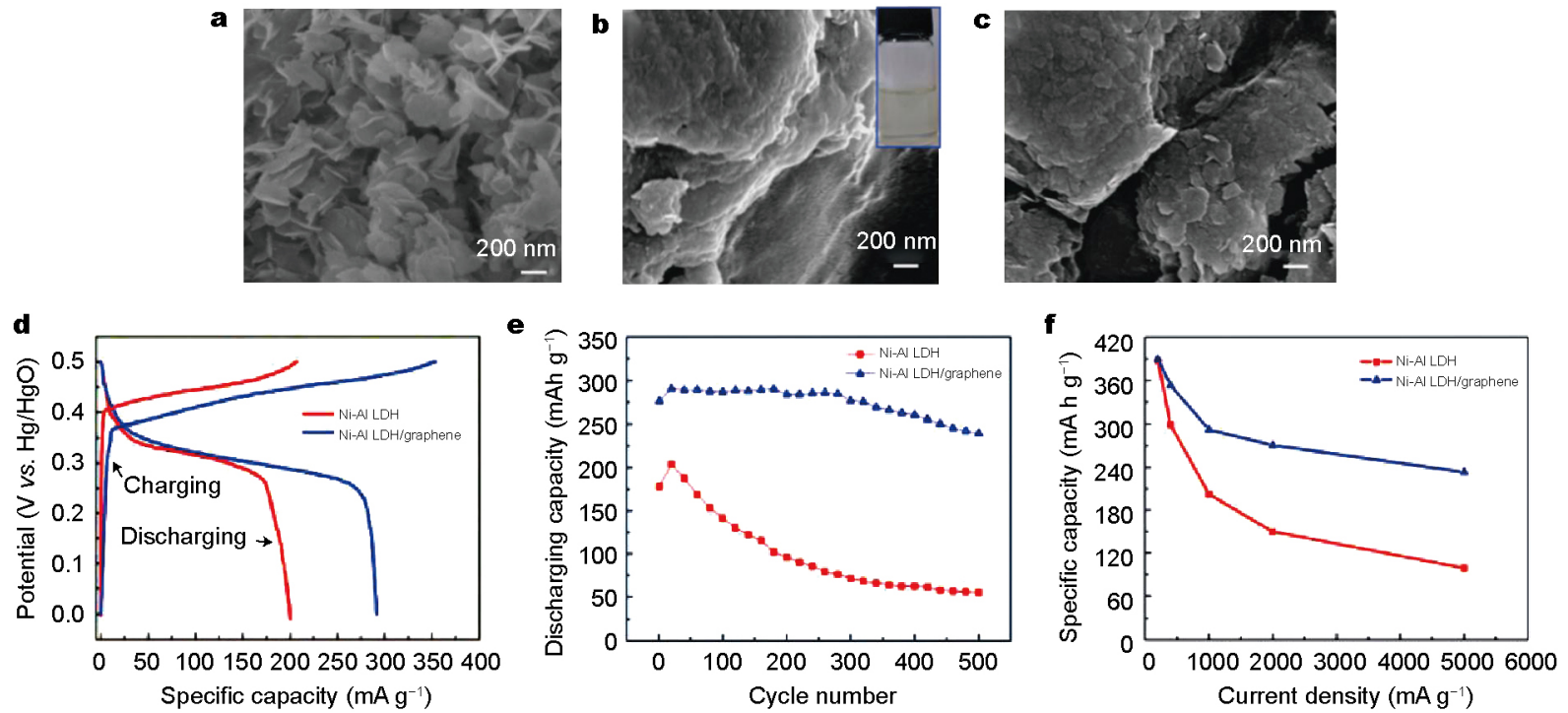

Figure 13 (a) SEM images of Ni-Al LDH nanoplatelets. (b) Ni-Al LDH-GO, inset, a certain amount of GO and a mass of delaminated Ni-Al LDHs mixed dispersions. (c) Ni-Al LDH-graphene composite. (d) Typical charge-discharge curves and (e) capacity maintaining plots at $1000 \mathrm{~mA} \mathrm{~g}{ }^{-1}$. (f) Rate property profiles of the $\mathrm{Ni}-\mathrm{Al} \mathrm{LDH}$ electrode and $\mathrm{Ni}-\mathrm{Al} \mathrm{LDH}$-graphene composite electrode between $200 \mathrm{~mA} \mathrm{~g}^{-1}$ and $5000 \mathrm{~mA} \mathrm{~g}{ }^{-1}$. Reproduced with permission from Ref. [261]. Copyright 2015, the Royal Society of Chemistry.

molar ratio of $\mathrm{Co} / \mathrm{Al}$, which is equivalent to $4: 1$. With the optimal molar ratio of $\mathrm{Co} / \mathrm{Al}$, the Co-Al-LDH composite displays a greatest hexagonal crystal construction. Among the pure nickel, $\mathrm{CoO}$ added nickel and $\mathrm{Co}_{4} \mathrm{Al} \mathrm{LDH}$ electrode, the latter has the most stable cycle performance and the highest discharge capacity. Besides, the high rate capability of the electrode can meet the requirements in high energy storage applications.

Gong et al. [265] demonstrated that the NiAlCo $\mathrm{LDH} / \mathrm{CNT}$ composite was successfully prepared as a novel electrode material. The material has stable structure due to the substitution of $\mathrm{Al}$ and $\mathrm{Co}$ in $\alpha-\mathrm{Ni}(\mathrm{OH})_{2}$. Also, it shows excellent electrochemical property, which is ascribed to the small ultrathin nanoplates morphology as well as the strong interaction between NiAlCo LDH nanoplates and CNTs. (Fig. 14c). A Ni-Zn battery was successfully fabricated using electro-deposited $\mathrm{Zn}$ as anode, NiAlCo LDH/CNT as cathode, delivering an energy density of 274 $\mathrm{W} \mathrm{h} \mathrm{kg} \mathrm{g}^{-1}$ and a power density of $16.6 \mathrm{~kW} \mathrm{~kg}^{-1}$, ultrafast charge/discharge times reaching to $41 \mathrm{~s}$.

\section{Zinc-aluminum layered double hydroxide (Zn-Al-LDH)}

In addition to above LDH mentioned, $\mathrm{Zn}-\mathrm{Al}-\mathrm{LDH}, \mathrm{Zn}-\mathrm{Al}-$ $\mathrm{La}-\mathrm{LDH}, \mathrm{Zn}-\mathrm{Sn}-\mathrm{Al}-\mathrm{LDH}$ and so on are regarded as advanced electrode materials for $\mathrm{Zn}-\mathrm{Ni}$ and $\mathrm{Ni}-\mathrm{Zn}$ secondary battery.

Xie et al. [266] have developed a facile hydrothermal method with anion-exchange processes subsequently for inserting dodecyl sulfate (DS) anions into LDHs interlayer to synthetize the $\mathrm{Zn}-\mathrm{Al}-\mathrm{CO}_{3} \mathrm{LDH}$. Compared to conventional LDHs, the dodecyl sulfate intercalated LDHs (LDHDS) show no change on the layer structure, but the crystallization becomes higher and the surface is much smoother. These as-synthesized LDH-DS samples not only deliver a higher specific discharge capacity of $375 \mathrm{~mA} \mathrm{~h} \mathrm{~g}^{-1}$ but also have superb cycle stability after 150 cycles (Fig. 14d, e). In addition, the active materials have been made in full use.

$\mathrm{Zn}$-Al-La-hydrotalcites with various $\mathrm{Al} / \mathrm{La}$ molar ratios were successfully prepared via co-precipitation by Fan et al. [267]. The hybrid has a hexagonal crystal structure, in which the degree of crystallization is also very high. As cathode material in a $\mathrm{Zn}-\mathrm{Ni}$ secondary battery, it displays splendid electrochemical properties, including reversibility, cycling stability, positive corrosion potential and excellent utilization ration, particularly in the case of $\mathrm{Al} / \mathrm{La}=$ $0.8 / 0.2$ (molar ratio).

Wang et al. [268] prepared Zn-Sn-Al-hydrotalcites LDHs successfully via the hydrothermal method. The structure and property of the compound electrode materials have been investigated. In contrast of $\mathrm{Zn}-\mathrm{Al}-\mathrm{LDH}$ without $\mathrm{Sn}$ addition, the $\mathrm{Zn}-\mathrm{Sn}$-Al-LDHs still present hexagon layer structure while show more excellent electrochemical performance (Fig. 14f, h).

$\mathrm{Zn}-\mathrm{Cu}-\mathrm{Al}-\mathrm{CO}_{3} \mathrm{LDHs}$ have been prepared via constant $\mathrm{pH}$ co-precipitation by Wen et al. [269]. It is regarded as another novel anodic material for $\mathrm{Zn}$-Ni secondary battery. 

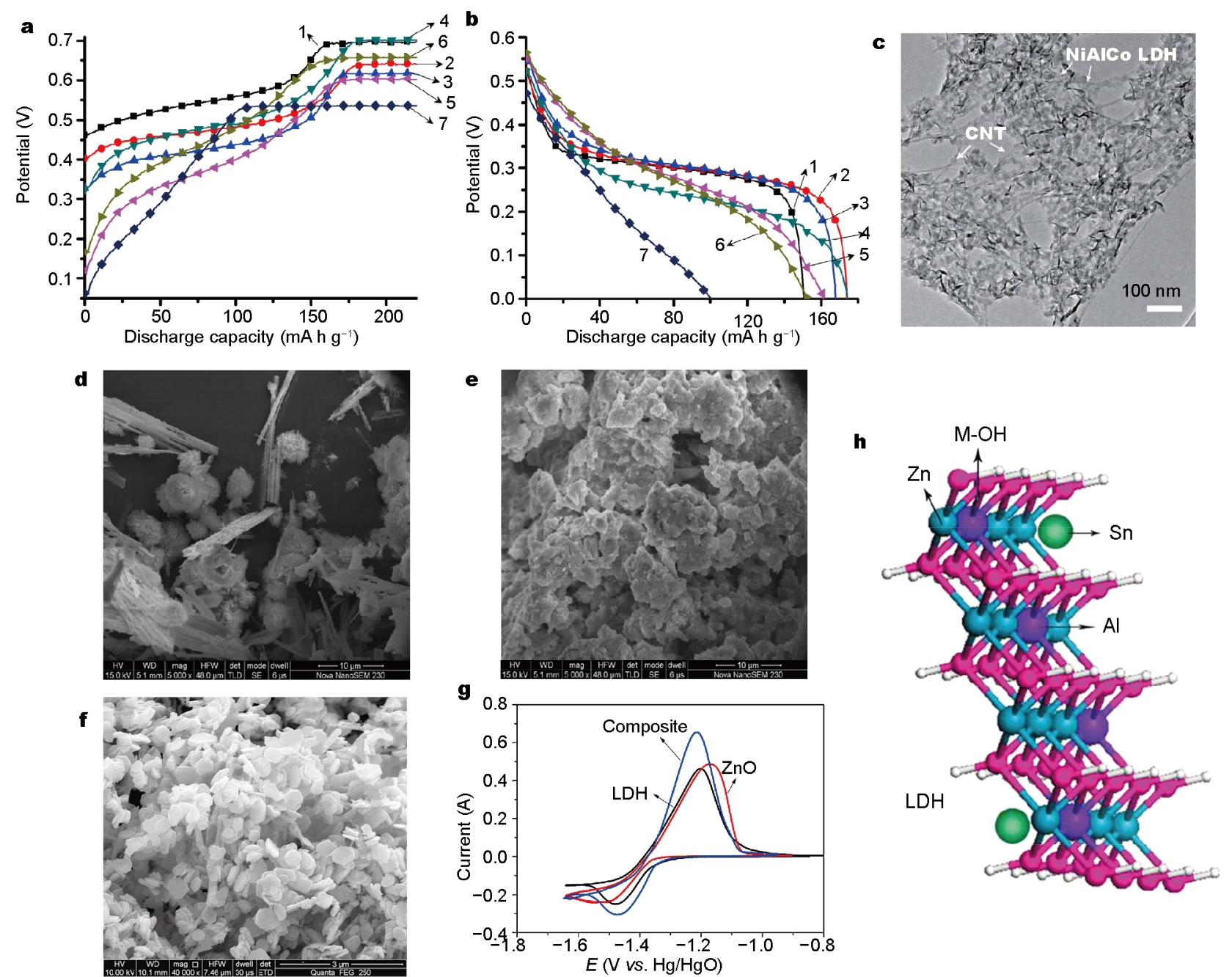

Figure 14 (a) Tenth charge and (b) discharge curves of $\mathrm{Ni}_{4-x} \mathrm{Co}_{x} \mathrm{Al}$ LDH samples (1 through 7 corresponding to $x=0,0.8,1.0,2.0,3.0,3.2,4.0$, respec-

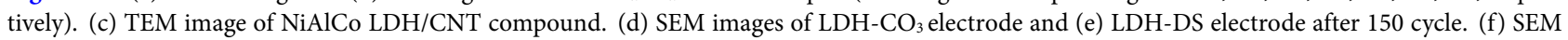
image for Zn-Sn-Al-LDH sample ( $\mathrm{Zn} / \mathrm{Sn} / \mathrm{Al}=2.8: 0.2: 1$ ). (g) CVs of the pure LDH, ZnO and LDH/CNTs. (h) Schematic diagram of Zn-Sn-Al-LDH after cycles. ( $\mathrm{a}$ and b) Reproduced with permission from Ref. [244]. Copyright 2013, Elsevier. (c) Reproduced with permission from Ref. [265]. Copyright 2014, the Royal Society of Chemistry. ( $\mathrm{d}$ and e) Reproduced with permission from Ref. [266]. Copyright 2014, Elsevier. (f and h) Reproduced with permission from Ref. [268]. Copyright 2014, Elsevier. (g) Reproduced with permission from Ref. [270]. Copyright 2013, Elsevier.

The $\mathrm{Zn}$ - $\mathrm{Cu}-\mathrm{Al}-\mathrm{LDH}$ with different $\mathrm{Zn} / \mathrm{Cu} / \mathrm{Al}$ molar ratios exhibit stable cycle performance, lower charge-transfer resistance and excellent reversibility. As $\mathrm{Zn} / \mathrm{Cu} / \mathrm{Al}=2.8 / 0.2 / 1$ (molar ratio), the electrochemical features of $\mathrm{Zn}-\mathrm{Cu}-\mathrm{Al}$ LDHs are deemed to be optimal than other samples.

Yang et al. [270] have prepared one kind of novel LDH/CNT composite by assembling nanostructured $\mathrm{Zn}-\mathrm{Al} \mathrm{LDH}$ and CNTs based on electrostatic force. The material has many obvious advantages. For example, compared with traditional $\mathrm{ZnO}$ and $\mathrm{Zn}-\mathrm{Al}-\mathrm{LDH}$, the LDH/CNT composite possesses excellent cycling stability. Meanwhile, it can maintain a discharge capacity of $390 \mathrm{~mA}$ $\mathrm{h} \mathrm{g}^{-1}$ after 200 cycles. Besides, it displays higher discharge plateau voltage and lower charge plateau voltage. In addition, the average utilization ration of the anode is up to 95.6\% (Fig. 14g). It is quite evident that the LDH/CNT composite shows a great promise employed as anode for $\mathrm{Ni}-\mathrm{Zn}$ batteries.

\section{SUMMARY AND OUTLOOK}

In this review, we have attempted to give a summary of some recent progress in micro/nanostructured Al-based materials for advanced battery systems, including LIBs, AIBs and Ni-MH alkaline secondary batteries. The creative synthetic method and unique design of the batteries get many problems effectively solved. For these Al-based 
materials, the electrochemical performances such as cycle life, rate capability and capacity are all inspiring. These improvements promote the development of Al-based chemistry and enrich the electrochemical energy storage devices.

For rechargeable LIBs [271,272], the lithiation-induced strain in electrodes often give rise to high stress, fracture, and capacity fade. By surface modification of $\mathrm{Al}_{2} \mathrm{O}_{3}, \mathrm{AlF}_{3}$, $\mathrm{AlPO}_{4}$, ect. and doping with $\mathrm{Al}^{3+}$, the electrochemical performance can be improved conspicuously. Developing multinary alloys is also an alternative technique to improve the electrochemical properties. Many evidences show that the Al-based materials are deemed to be potential electrode materials for LIBs.

AIBs have similar operating principles as LIBs, which are ideal for energy storage on a large scale in the future. Traditional AIBs usually have short cycle life, slow ion transport, decomposition of cathode and low discharge voltage plateaus on account of the difficulty to find a suitable cathode material and choose a right electrolyte. Until the first functional rechargeable AIB was designed, further opportunities showed up for improvement in the electrochemical property of the AIBs. The battery using an $\mathrm{Al}$ metal as anode, $\mathrm{V}_{2} \mathrm{O}_{5}$ nanowires as cathode, and an ionic liquid/ $/ \mathrm{AlCl}_{3}$ based solution as electrolyte displayed quite encouraging electrochemical stability. Although its energy density was not very high, it was enough to inspire a new wave of global research for new materials and innovative designs of AIBs. Numerous studies on developing new intercalation materials and electrolytes help provide a bright prospect of the application of AIBs. Nowadays, it is of great interest to explore the performance of AIBs in order to satisfy the requirements of commercial AIBs.

Beyond the recent research progress of nanostructured Al-based materials for LIBs and the development of AIBs, another topic to explore is micro/nanostructured Al-based materials in Ni-MH alkaline secondary batteries. A large amount of Ni-Al $\mathrm{LDH}$ composites such as Ni-Al LDH/C, Ni-Al LDH-graphene, Co-Al-LDH, NiAlCo LDH/CNT, Zn-Al-LDH, Zn-Al-La-LDH, Zn-Sn-Al-LDH, $\mathrm{Zn}-\mathrm{Cu}-\mathrm{Al}-\mathrm{LDH}$ and $\mathrm{Zn}-\mathrm{Al}-\mathrm{LDH} / \mathrm{CNT}$ have been investigated. The electric conductivity, crystallization and the utilization ration of $\mathrm{LDH}$ materials have been significantly improved in these composites. Therefore, they exhibit superb electrochemical performance as electrode materials in Ni-MH alkaline secondary batteries.

During the past decade, great achievements have been made in Al-based materials for advanced battery systems. However, most of the breakthroughs are in the stage of lab- oratory, with no production yet for a mass market offering. It is filled with challenges on the road to commercial functional batteries which use Al-based materials. Therefore, a comprehensive and in-depth understanding of the Al-based chemistry is necessary. There are complex material conversions and structure evolutions taking place during the electrochemical reactions, particularly as it relates to the nanosized domains. The relations between structure and property and the electrochemical mechanisms of the batteries using Al-based materials must be taken into account. It is anticipated that future researches will be devoted to purposefully design and apply Al-based materials which can be produced on an industrial scale, facilely and cheaply. Under the circumstances, more experimental measurements, mathematical modeling and theoretical simulation are required.

Besides building a comprehensive understanding of the reaction mechanisms to optimize design, another topic is to effectively reduce irreversible capacity loss. The investigation on micro/nanostructured Al-based materials needs attach importance to the interface issues and the compatibility of electrolyte since the inserted charge would be unable to all remove during the first discharge while electrolyte would be reduced on the electrode surface. Proper modification of electrode materials and electrolytes could remarkably enhance the overall electrochemical property of batteries. And studies need pay attention to increasing the initial coulombic efficiency for the commercialization of Al-based materials in advanced battery systems.

To realize commercialization of micro/nanostructured Al-based materials in electrochemical energy storage devices, more work must to be done. The cost, safety, volumetric energy density and compatibility and so on all need to be fully considered. $\mathrm{Al}$ is an abundant natural element, and the raw material is relatively cheap and environment-friendly. The availably applications are being in the stage of research and development. Thanks to the progress of the modern science and technology, innovative materials and research design could make advanced battery systems be full of infinite possibilities. We believe the further exploration in this field will bring about more exciting achievements.

Received 30 March 2017; accepted 2 June 2017; published online 4 July 2017

1 Armand M, Tarascon JM. Building better batteries. Nature, 2008, 451: 652-657

2 Liu C, Li F, Ma LP, et al. Advanced materials for energy storage. Adv Mater, 2010, 22: E28-E62

3 Cheng F, Liang J, Tao Z, et al. Functional materials for rechargeable 
batteries. Adv Mater, 2011, 23: 1695-1715

4 Goodenough JB, Kim Y. Challenges for rechargeable batteries. J Power Sources, 2011, 196: 6688-6694

5 Bruce PG, Scrosati B, Tarascon JM. Nanomaterials for rechargeable lithium batteries. Angew Chem Int Ed, 2008, 47: 2930-2946

6 Gao XP, Yang HX. Multi-electron reaction materials for high energy density batteries. Energ Environ Sci, 2010, 3: 174-189

7 Li H, Wang Z, Chen L, et al. Research on advanced materials for Li-ion batteries. Adv Mater, 2009, 21: 4593-4607

8 Winter M, Brodd RJ. What are batteries, fuel cells, and supercapacitors? Chem Rev, 2004, 104: 4245-4270

9 Dominko R, Arčon D, Mrzel A, et al. Dichalcogenide nanotube electrodes for Li-ion batteries. Adv Mater, 2002, 14: 1531-1534

10 Park CM, Kim JH, Kim H, et al. Li-alloy based anode materials for Li secondary batteries. Chem Soc Rev, 2010, 39: 3115-3141

11 Brutti S, Gentili V, Menard $\mathrm{H}$, et al. $\mathrm{TiO}_{2}-(\mathrm{B})$ nanotubes as anodes for lithium batteries: origin and mitigation of irreversible capacity. Adv Energ Mater, 2012, 2: 322-327

12 Lindsay MJ, Wang GX, Liu HK. Al-based anode materials for Li-ion batteries. J Power Sources, 2003, 119-121: 84-87

13 Hamon Y, Brousse T, Jousse F, et al. Aluminum negative electrode in lithium ion batteries. J Power Sources, 2001, 97-98: 185-187

14 Fauteux D, Koksbang R. Rechargeable lithium battery anodes: alternatives to metallic lithium. J Appl Electrochem, 1993, 23: 1-10

15 Kim SW, Seo DH, Ma X, et al. Electrode materials for rechargeable sodium-ion batteries: potential alternatives to current lithium-ion batteries. Adv Energ Mater, 2012, 2: 710-721

$16 \mathrm{Li}$ Q, Bjerrum NJ. Aluminum as anode for energy storage and conversion: a review. J Power Sources, 2002, 110: 1-10

17 Sun $\mathrm{D}$, Xu G, Wang $\mathrm{H}$, et al. Multi-layered $\mathrm{Al}_{2} \mathrm{O}_{3} / \mathrm{Li}_{x} \mathrm{~V}_{2} \mathrm{O}_{5} / \mathrm{LiV}_{3} \mathrm{O}_{8}$ nanoflakes with superior cycling stability as cathode material for Li-ion battery. Electrochim Acta, 2015, 157: 211-217

18 Hu YS, Demir-Cakan R, Titirici MM, et al. Superior storage performance of a $\mathrm{Si} @ \mathrm{SiO}_{x} / \mathrm{C}$ nanocomposite as anode material for lithium-ion batteries. Angew Chem Int Ed, 2008, 47: 1645-1649

19 Gao P, Fu J, Yang J, et al. Microporous carbon coated silicon core/shell nanocomposite via in situ polymerization for advanced Li-ion battery anode material. Phys Chem Chem Phys, 2009, 11: 11101

20 Li H. The crystal structural evolution of nano-Si anode caused by lithium insertion and extraction at room temperature. Solid State Ion, 2000, 135: 181-191

21 Chan CK, Peng H, Liu G, et al. High-performance lithium battery anodes using silicon nanowires. Nat Nanotech, 2008, 3: 31-35

22 Kim H, Cho J. Superior lithium electroactive mesoporous Si@carbon core-shell nanowires for lithium battery anode material. Nano Lett, 2008, 8: 3688-3691

23 Wang W, Kumta PN. Nanostructured hybrid silicon/carbon nanotube heterostructures: reversible high-capacity lithium-ion anodes. ACS Nano, 2010, 4: 2233-2241

24 Jung H, Park M, Han SH, et al. Amorphous silicon thin-film negative electrode prepared by low pressure chemical vapor deposition for lithium-ion batteries. Solid State Commun, 2003, 125: 387-390

25 Takamura T, Ohara S, Uehara M, et al. A vacuum deposited Si film having a Li extraction capacity over $2000 \mathrm{mAh} / \mathrm{g}$ with a long cycle life. J Power Sources, 2004, 129: 96-100

26 Maranchi JP, Hepp AF, Kumta PN. High capacity, reversible silicon thin-film anodes for lithium-ion batteries. Electrochem Solid-State Lett, 2003, 6: A198

27 Zhang Y, Fu ZW, Qin QZ. Microstructure and Li alloy formation of nano-structured amorphous $\mathrm{Si}$ and $\mathrm{Si} / \mathrm{TiN}$ composite thin film electrodes. Electrochem Commun, 2004, 6: 484-491
28 Aurbach D, Markovsky B, Talyossef Y, et al. Studies of cycling behavior, ageing, and interfacial reactions of $\mathrm{LiNi}_{0.5} \mathrm{Mn}_{1.5} \mathrm{O}_{4}$ and carbon electrodes for lithium-ion 5-V cells. J Power Sources, 2006, 162: 780-789

29 Feldgitscher C, Peterlik H, Puchberger M, et al. Structural investigations on hybrid polymers suitable as a nanoparticle precipitation environment. Chem Mater, 2009, 21: 695-705

30 Duncan H, Abu-Lebdeh Y, Davidson IJ. Study of the cathode-electrolyte interface of $\mathrm{LiMn}_{1.5} \mathrm{Ni}_{0.5} \mathrm{O}_{4}$ synthesized by a sol-gel method for Li-ion batteries. J Electrochem Soc, 2010, 157: A528

31 Dedryvère R, Foix D, Franger S, et al. Electrode/electrolyte interface reactivity in high-voltage spinel $\mathrm{LiMn}_{1.6} \mathrm{Ni}_{0.4} \mathrm{O}_{4} / \mathrm{Li}_{4} \mathrm{Ti}_{5} \mathrm{O}_{12}$ lithium-ion battery. J Phys Chem C, 2010, 114: 10999-11008

32 He Y, Yu X, Wang Y, et al. Alumina-coated patterned amorphous silicon as the anode for a lithium-ion battery with high coulombic efficiency. Adv Mater, 2011, 23: 4938-4941

33 Li GR, Feng X, Ding Y, et al. $\mathrm{AlF}_{3}$-coated $\mathrm{Li}\left(\mathrm{Li}_{0.17} \mathrm{Ni}_{0.25} \mathrm{Mn}_{0.58}\right) \mathrm{O}_{2}$ as cathode material for Li-ion batteries. Electrochim Acta, 2012, 78: 308-315

34 Qiao QQ, Zhang HZ, Li GR, et al. Surface modification of Li-rich layered $\mathrm{Li}\left(\mathrm{Li}_{0.17} \mathrm{Ni}_{0.25} \mathrm{Mn}_{0.58}\right) \mathrm{O}_{2}$ oxide with $\mathrm{Li}-\mathrm{Mn}-\mathrm{PO}_{4}$ as the cathode for lithium-ion batteries. J Mater Chem A, 2013, 1: 5262-5268

35 Kim MG, Jo M, Hong YS, et al. Template-free synthesis of $\mathrm{Li}\left[\mathrm{Ni}_{0.25} \mathrm{Li}_{0.15} \mathrm{Mn}_{0.6}\right] \mathrm{O}_{2}$ nanowires for high performance lithium battery cathode. Chem Commun, 2009, 47: 218-220

36 Seok Jung Y, Cavanagh AS, Yan Y, et al. Effects of atomic layer deposition of $\mathrm{Al}_{2} \mathrm{O}_{3}$ on the $\mathrm{Li}\left[\mathrm{Li}_{0.20} \mathrm{Mn}_{0.54} \mathrm{Ni}_{0.13} \mathrm{Co}_{0.13}\right] \mathrm{O}_{2}$ cathode for lithium-ion batteries. J Electrochem Soc, 2011, 158: A1298

37 Shi SJ, Tu JP, Mai YJ, et al. Effect of carbon coating on electrochemical performance of $\mathrm{Li}_{1.048} \mathrm{Mn}_{0.381} \mathrm{Ni}_{0.286} \mathrm{Co}_{0.286} \mathrm{O}_{2}$ cathode material for lithium-ion batteries. Electrochim Acta, 2012, 63: 112-117

$38 \mathrm{Li} \mathrm{H}$, Zhou H. Enhancing the performances of Li-ion batteries by carbon-coating: present and future. Chem Commun, 2012, 48: 1201-1217

39 Kim WK, Han DW, Ryu WH, et al. $\mathrm{Al}_{2} \mathrm{O}_{3}$ coating on $\mathrm{LiMn}_{2} \mathrm{O}_{4}$ by electrostatic attraction forces and its effects on the high temperature cyclic performance. Electrochim Acta, 2012, 71: 17-21

40 He W, Qian J, Cao Y, et al. Improved electrochemical performances of nanocrystalline $\mathrm{Li}\left[\mathrm{Li}_{0.2} \mathrm{Mn}_{0.54} \mathrm{Ni}_{0.13} \mathrm{Co}_{0.13}\right] \mathrm{O}_{2}$ cathode material for Li-ion batteries. RSC Adv, 2012, 2: 3423-3429

41 Pang S, Wang $\mathrm{Y}$, Chen $\mathrm{T}$, et al. The effect of $\mathrm{AlF}_{3}$ modification on the physicochemical and electrochemical properties of Li-rich layered oxide. Ceramics Int, 2016, 42: 5397-5402

42 Deng H, Belharouak I, Yoon CS, et al. High temperature performance of surface-treated $\mathrm{Li}{ }_{1.1}\left(\mathrm{Ni}_{0.15} \mathrm{Co}_{0.1} \mathrm{Mn}_{0.55}\right) \mathrm{O}_{1.95}$ layered oxide. J Electrochem Soc, 2010, 157: A1035

43 Sun $\mathrm{YK}$, Cho SW, Lee SW, et al. $\mathrm{AlF}_{3}$-coating to improve high voltage cycling performance of $\mathrm{Li}\left[\mathrm{Ni}_{1 / 3} \mathrm{Co}_{1 / 3} \mathrm{Mn}_{1 / 3}\right] \mathrm{O}_{2}$ cathode materials for lithium secondary batteries. J Electrochem Soc, 2007, 154: A168

44 Yang K, Fan LZ, Guo J, et al. Significant improvement of electrochemical properties of $\mathrm{AlF}_{3}$-coated $\mathrm{LiNi}_{0.5} \mathrm{Co}_{0.2} \mathrm{Mn}_{0.3} \mathrm{O}_{2}$ cathode materials. Electrochim Acta, 2012, 63: 363-368

45 Liu B, Zhang Q, He S, et al. Improved electrochemical properties of $\mathrm{Li}_{1.2} \mathrm{Ni}_{0.18} \mathrm{Mn}_{0.59} \mathrm{Co}_{0.03} \mathrm{O}_{2}$ by surface modification with $\mathrm{LiCoPO}_{4}$. Electrochim Acta, 2011, 56: 6748-6751

46 Kim HB, Park BC, Myung ST, et al. Electrochemical and thermal characterization of $\mathrm{AlF}_{3}$-coated $\mathrm{Li}\left[\mathrm{Ni}_{0.8} \mathrm{Co}_{0.15} \mathrm{Al}_{0.05}\right] \mathrm{O}_{2}$ cathode in lithium-ion cells. J Power Sources, 2008, 179: 347-350

47 Zheng JM, Zhang ZR, Wu XB, et al. The effects of $\mathrm{AlF}_{3}$ coating on the performance of $\mathrm{Li}\left[\mathrm{Li}_{0.2} \mathrm{Mn}_{0.54} \mathrm{Ni}_{0.13} \mathrm{Co}_{0.13}\right] \mathrm{O}_{2}$ positive electrode material for lithium-ion battery. J Electrochem Soc, 2008, 155: 
A775

48 Kim JW, Kim DH, Oh DY, et al. Surface chemistry of $\mathrm{LiNi}_{0.5} \mathrm{Mn}_{1.5} \mathrm{O}_{4}$ particles coated by $\mathrm{Al}_{2} \mathrm{O}_{3}$ using atomic layer deposition for lithiumion batteries. J Power Sources, 2015, 274: 1254-1262

49 Huang B, Li X, Wang Z, et al. A novel carbamide-assistant hydrothermal process for coating $\mathrm{Al}_{2} \mathrm{O}_{3}$ onto $\mathrm{LiMn}_{1.5} \mathrm{Ni}_{0.5} \mathrm{O}_{4}$ particles used for cathode material of lithium-ion batteries. J Alloys Compd, 2014, 583: 313-319

50 Riley LA, Van Atta S, Cavanagh AS, et al. Electrochemical effects of ALD surface modification on combustion synthesized $\mathrm{LiNi}_{1 / 3} \mathrm{Mn}_{1 / 3} \mathrm{Co}_{1 / 3} \mathrm{O}_{2}$ as a layered-cathode material. J Power Sources, 2011, 196: 3317-3324

51 Huang $\mathrm{Y}$, Chen J, Cheng $\mathrm{F}$, et al. A modified $\mathrm{Al}_{2} \mathrm{O}_{3}$ coating process to enhance the electrochemical performance of $\mathrm{Li}\left(\mathrm{Ni}_{1 / 3} \mathrm{Co}_{1 / 3} \mathrm{Mn}_{1 / 3}\right) \mathrm{O}_{2}$ and its comparison with traditional $\mathrm{Al}_{2} \mathrm{O}_{3}$ coating process. J Power Sources, 2010, 195: 8267-8274

52 Fey GTK, Chang CS, Kumar TP. Synthesis and surface treatment of $\mathrm{LiNi}_{1 / 3} \mathrm{Co}_{1 / 3} \mathrm{Mn}_{1 / 3} \mathrm{O}_{2}$ cathode materials for $\mathrm{Li}$-ion batteries. J Solid State Electrochem, 2010, 14: 17-26

53 Cheng F, Xin Y, Huang Y, et al. Enhanced electrochemical performances of $5 \mathrm{~V}$ spinel $\mathrm{LiMn}_{1.58} \mathrm{Ni}_{0.42} \mathrm{O}_{4}$ cathode materials by coating with $\mathrm{LiAlO}_{2}$. J Power Sources, 2013, 239: 181-188

54 Memarzadeh EL, Kalisvaart WP, Kohandehghan A, et al. Silicon nanowire core aluminum shell coaxial nanocomposites for lithium ion battery anodes grown with and without a TiN interlayer. J Mater Chem, 2012, 22: 6655-6668

55 Hwang G, Park H, Bok T, et al. A high-performance nanoporous $\mathrm{Si} / \mathrm{Al}_{2} \mathrm{O}_{3}$ foam lithium-ion battery anode fabricated by selective chemical etching of the Al-Si alloy and subsequent thermal oxidation. Chem Commun, 2015, 51: 4429-4432

56 Panero S. Rechargeable $\mathrm{Li} / \mathrm{Li}_{1+x} \mathrm{~V}_{3} \mathrm{O}_{8}$ cells. J Electrochem Soc, 1983, 130: $1225-1227$

57 Kawakita J, Miura T, Kishi T. Lithium insertion and extraction kinetics of $\mathrm{Li}_{1+x} \mathrm{~V}_{3} \mathrm{O}_{8}$. J Power Sources, 1999, 83: 79-83

58 Gao XW, Wang JZ, Chou SL, et al. Synthesis and electrochemical performance of $\mathrm{LiV}_{3} \mathrm{O}_{8}$ /polyaniline as cathode material for the lithium battery. J Power Sources, 2012, 220: 47-53

59 Benedek R, Thackeray MM, Yang LH. First-principles calculation of atomic structure and electrochemical potential of $\mathrm{Li}_{1+x} \mathrm{~V}_{3} \mathrm{O}_{8}$. J Power Sources, 1999, 81-82: 487-490

60 Jouanneau S, Le Gal La Salle A, Verbaere A, et al. The origin of capacity fading upon lithium cycling in $\mathrm{Li}_{1.1} \mathrm{~V}_{3} \mathrm{O}_{8}$. J Electrochem Soc, 2005, 152: A1660

61 Huang S, Tu JP, Jian XM, et al. Enhanced electrochemical properties of $\mathrm{Al}_{2} \mathrm{O}_{3}$-coated $\mathrm{LiV}_{3} \mathrm{O}_{8}$ cathode materials for high-power lithium-ion batteries. J Power Sources, 2014, 245: 698-705

62 Mo R, Du Y, Zhang N, et al. Surface modification of $\mathrm{LiV}_{3} \mathrm{O}_{8}$ nanosheets via layer-by-layer self-assembly for high-performance rechargeable lithium batteries. J Power Sources, 2014, 257: 319-324

63 Lee J, Lee CL, Park K, et al. Synthesis of an $\mathrm{Al}_{2} \mathrm{O}_{3}$-coated polyimide nanofiber mat and its electrochemical characteristics as a separator for lithium ion batteries. J Power Sources, 2014, 248: 1211-1217

64 Yang $\mathrm{Z}$, Wu H. Electrochemical intercalation of lithium into raw carbon nanotubes. Mater Chem Phys, 2001, 71: 7-11

65 Frackowiak E, Béguin F. Electrochemical storage of energy in carbon nanotubes and nanostructured carbons. Carbon, 2002, 40: 1775-1787

66 Shin HC, Liu M, Sadanadan B, et al. Electrochemical insertion of lithium into multi-walled carbon nanotubes prepared by catalytic decomposition. J Power Sources, 2002, 112: 216-221

67 Lahiri I, Oh SW, Hwang JY, et al. High capacity and excellent stabil- ity of lithium ion battery anode using interface-controlled binderfree multiwall carbon nanotubes grown on copper. ACS Nano, 2010, 4: 3440-3446

68 Lahiri I, Oh SM, Hwang JY, et al. Ultrathin alumina-coated carbon nanotubes as an anode for high capacity Li-ion batteries. J Mater Chem, 2011, 21: 13621-13626

$69 \mathrm{Kim} \mathrm{K}, \mathrm{Kim} \mathrm{Y}, \mathrm{Oh} \mathrm{ES}$, et al. The role of fluoride in protecting $\mathrm{LiNi}_{0.5} \mathrm{Mn}_{1.5} \mathrm{O}_{4}$ electrodes against high temperature degradation. Electrochim Acta, 2013, 114: 387-393

70 Xiong $\mathrm{X}$, Wang $\mathrm{Z}$, Yin $\mathrm{X}$, et al. A modified LiF coating process to enhance the electrochemical performance characteristics of $\mathrm{LiNi}_{0.8} \mathrm{Co}_{0.1} \mathrm{Mn}_{0.1} \mathrm{O}_{2}$ cathode materials. Mater Lett, 2013, 110: 4-9

71 Sun $\mathrm{YK}$, Lee MJ, Yoon CS, et al. The role of $\mathrm{AlF}_{3}$ coatings in improving electrochemical cycling of Li-enriched nickel-manganese oxide electrodes for Li-ion batteries. Adv Mater, 2012, 24: 1192-1196

72 Cho E, Mun J, Chae OB, et al. Corrosion/passivation of aluminum current collector in bis(fluorosulfonyl)imide-based ionic liquid for lithium-ion batteries. Electrochem Commun, 2012, 22: 1-3

73 Liu H, Tang D. The effect of nanolayer $\mathrm{AlF}_{3}$ coating on $\mathrm{LiMn}_{2} \mathrm{O}_{4}$ cycle life in high temperature for lithium secondary batteries. Russ J Electrochem, 2009, 45: 762-764

74 Myung ST, Amine K, Sun YK. Surface modification of cathode materials from nano- to microscale for rechargeable lithium-ion batteries. J Mater Chem, 2010, 20: 7074-7095

75 Wang MS, Wang J, Zhang J, et al. Improving electrochemical performance of spherical $\mathrm{LiMn}_{2} \mathrm{O}_{4}$ cathode materials for lithium ion batteries by Al-F codoping and $\mathrm{AlF}_{3}$ surface coating. Ion, 2015, 21 : 27-35

76 Zheng J, Gu M, Xiao J, et al. Functioning mechanism of $\mathrm{AlF}_{3}$ coating on the Li- and Mn-rich cathode materials. Chem Mater, 2014, 26: 6320-6327

77 Wu Q, Yin $\mathrm{Y}$, Sun $\mathrm{S}$, et al. Novel $\mathrm{AlF}_{3}$ surface modified spinel $\mathrm{LiMn}_{1.5} \mathrm{Ni}_{0.5} \mathrm{O}_{4}$ for lithium-ion batteries: performance characterization and mechanism exploration. Electrochim Acta, 2015, 158: 73-80

78 Lee SH, Yoon CS, Amine K, et al. Improvement of long-term cycling performance of $\mathrm{Li}\left[\mathrm{Ni}_{0.8} \mathrm{Co}_{0.15} \mathrm{Al}_{0.05}\right] \mathrm{O}_{2}$ by $\mathrm{AlF}_{3}$ coating. J Power Sources, 2013, 234: 201-207

79 Rosina KJ, Jiang M, Zeng D, et al. Structure of aluminum fluoride coated $\mathrm{Li}\left[\mathrm{Li}_{1 / 9} \mathrm{Ni}_{1 / 3} \mathrm{Mn}_{5 / 9}\right] \mathrm{O}_{2}$ cathodes for secondary lithiumion batteries. J Mater Chem, 2012, 22: 20602-20610

80 Lee DJ, Lee KS, Myung ST, et al. Improvement of electrochemical properties of $\mathrm{Li}_{1.1} \mathrm{Al}_{0.05} \mathrm{Mn}_{1.85} \mathrm{O}_{4}$ achieved by an $\mathrm{AlF}_{3}$ coating. J Power Sources, 2011, 196: 1353-1357

81 Tron A, Park YD, Mun J. $\mathrm{AlF}_{3}$-coated $\mathrm{LiMn}_{2} \mathrm{O}_{4}$ as cathode material for aqueous rechargeable lithium battery with improved cycling stability. J Power Sources, 2016, 325: 360-364

82 Zhu Z, Cai F, Yu J. Improvement of electrochemical performance for $\mathrm{AlF}_{3}$-coated $\mathrm{Li}_{1.3} \mathrm{Mn}_{4 / 6} \mathrm{Ni}_{1 / 6} \mathrm{Co}_{1 / 6} \mathrm{O}_{2.40}$ cathode materials for Li-ion batteries. Ion, 2016, 22: 1353-1359

83 Wang $\mathrm{H}$, $\mathrm{Yu} \mathrm{Y}$, Jin $\mathrm{G}$, et al. $\mathrm{AlF}_{3}$ coated $\mathrm{LiV}_{3} \mathrm{O}_{8}$ nanosheets with significantly improved cycling stability as cathode material for Li-ion battery. Solid State Ion, 2013, 236: 37-42

84 Ding F, Xu W, Choi D, et al. Enhanced performance of graphite anode materials by $\mathrm{AlF}_{3}$ coating for lithium-ion batteries. J Mater Chem, 2012, 22: 12745-12751

$85 \mathrm{Li} \mathrm{W}, \mathrm{Li} \mathrm{X}$, Chen $\mathrm{M}$, et al. $\mathrm{AlF}_{3}$ modification to suppress the gas generation of $\mathrm{Li}_{4} \mathrm{Ti}_{5} \mathrm{O}_{12}$ anode battery. Electrochim Acta, 2014, 139: 104-110

86 Cho J, Kim YW, Kim B, et al. A breakthrough in the safety of lithium secondary batteries by coating the cathode material with $\mathrm{AlPO}_{4}$ nanoparticles. Angew Chem Int Ed, 2003, 42: 1618-1621 
87 Kim B, Lee JG, Choi M, et al. Correlation between local strain and cycle-life performance of $\mathrm{AlPO}_{4}$-coated $\mathrm{LiCoO}_{2}$ cathodes. J Power Sources, 2004, 126: 190-192

88 Cho J, Kim TJ, Kim J, et al. Synthesis, thermal, and electrochemical properties of $\mathrm{AlPO}_{4}$-coated $\mathrm{LiNi}_{0.8} \mathrm{Co}_{0.1} \mathrm{Mn}_{0.1} \mathrm{O}_{2}$ cathode materials for a Li-ion cell. J Electrochem Soc, 2004, 151: A1899

89 Lee JG, Kim B, Cho J, et al. Effect of $\mathrm{AlPO}_{4}$-nanoparticle coating concentration on high-cutoff-voltage electrochemical performances in $\mathrm{LiCoO}_{2}$. J Electrochem Soc, 2004, 151: A801

90 Padhi AK. Phospho-olivines as positive-electrode materials for rechargeable lithium batteries. J Electrochem Soc, 1997, 144: 1188-1194

91 Appapillai AT, Mansour AN, Cho J, et al. Microstructure of $\mathrm{LiCoO}_{2}$ with and without " $\mathrm{AlPO}_{4}$ " nanoparticle coating: combined STEM and XPS studies. Chem Mater, 2007, 19: 5748-5757

92 Lu YC, Mansour AN, Yabuuchi N, et al. Probing the origin of enhanced stability of "AlPO" nanoparticle coated $\mathrm{LiCoO}_{2}$ during cycling to high voltages: combined XRD and XPS studies. Chem Mater, 2009, 21: 4408-4424

93 Wu Y, Vadivel Murugan A, Manthiram A. Surface modification of high capacity layered $\mathrm{Li}\left[\mathrm{Li}_{0.2} \mathrm{Mn}_{0.54} \mathrm{Ni}_{0.13} \mathrm{Co}_{0.13}\right] \mathrm{O}_{2}$ cathodes by $\mathrm{AlPO}_{4}$. J Electrochem Soc, 2008, 155: A635

94 Cho J, Lee JG, Kim B, et al. Effect of $\mathrm{P}_{2} \mathrm{O}_{5}$ and $\mathrm{AlPO}_{4}$ coating on $\mathrm{LiCoO}_{2}$ cathode material. Chem Mater, 2003, 15: 3190-3193

95 Kim B, Kim C, Ahn D, et al. Nanostructural effect of $\mathrm{AlPO}_{4}$-nanoparticle coating on the cycle-life performance in $\mathrm{LiCoO}_{2}$ thin films. Electrochem Solid-State Lett, 2007, 10: A32

96 Zeng Y, He J. Surface structure investigation of $\mathrm{LiNi}_{0.8} \mathrm{Co}_{0.2} \mathrm{O}_{2}$ by $\mathrm{AlPO}_{4}$ coating and using functional electrolyte. J Power Sources, 2009, 189: 519-521

97 Liu D, He Z, Liu X. Increased cycling stability of $\mathrm{AlPO}_{4}$-coated $\mathrm{LiMn}_{2} \mathrm{O}_{4}$ for lithium ion batteries. Mater Lett, 2007, 61: 4703-4706

98 Jiao L, Liu L, Sun J, et al. Effect of $\mathrm{AlPO}_{4}$ nanowire coating on the electrochemical properties of $\mathrm{LiV}_{3} \mathrm{O}_{8}$ cathode material. J Phys Chem C, 2008, 112: 18249-18254

99 Shi JY, Yi CW, Kim K. Improved electrochemical performance of $\mathrm{AlPO}_{4}$-coated $\mathrm{LiMn}_{1.5} \mathrm{Ni}_{0.5} \mathrm{O}_{4}$ electrode for lithium-ion batteries. J Power Sources, 2010, 195: 6860-6866

100 Ma J, Li B, An L, et al. A highly homogeneous nanocoating strategy for Li-rich Mn-based layered oxides based on chemical conversion. J Power Sources, 2015, 277: 393-402

101 Wu F, Zhang X, Zhao T, et al. Multifunctional $\mathrm{AlPO}_{4}$ coating for improving electrochemical properties of low-cost $\mathrm{Li}\left[\mathrm{Li}_{0.2} \mathrm{Fe}_{0.1} \mathrm{Ni}_{0.15} \mathrm{Mn}_{0.55}\right] \mathrm{O}_{2}$ cathode materials for lithium-ion batteries. ACS Appl Mater Interfaces, 2015, 7: 3773-3781

102 Jung H, Park M, Yoon YG, et al. Amorphous silicon anode for lithium-ion rechargeable batteries. J Power Sources, 2003, 115: 346-351

103 Kasavajjula U, Wang C, Appleby AJ. Nano- and bulk-silicon-based insertion anodes for lithium-ion secondary cells. J Power Sources, 2007, 163: 1003-1039

104 Zein El Abedin S, Borissenko N, Endres F. Electrodeposition of nanoscale silicon in a room temperature ionic liquid. Electrochem Commun, 2004, 6: 510-514

105 Nguyen HT, Zamfir MR, Duong LD, et al. Alumina-coated siliconbased nanowire arrays for high quality Li-ion battery anodes. J Mater Chem, 2012, 22: 24618-24626

106 Chan CK, Patel RN, O'Connell MJ, et al. Solution-grown silicon nanowires for lithium-ion battery anodes. ACS Nano, 2010, 4: 1443-1450

107 Wang W, Epur R, Kumta PN. Vertically aligned silicon/carbon nanotube (VASCNT) arrays: hierarchical anodes for lithium-ion bat- tery. Electrochem Commun, 2011, 13: 429-432

108 Murugesan S, Harris JT, Korgel BA, et al. Copper-coated amorphous silicon particles as an anode material for lithium-ion batteries. Chem Mater, 2012, 24: 1306-1315

109 Xue L, Fu K, Li Y, et al. Si/C composite nanofibers with stable electric conductive network for use as durable lithium-ion battery anode. Nano Energ, 2013, 2: 361-367

110 Szczech JR, Jin S. Nanostructured silicon for high capacity lithium battery anodes. Energ Environ Sci, 2011, 4: 56-72

111 Wang B, Li X, Qiu T, et al. High volumetric capacity silicon-based lithium battery anodes by nanoscale system engineering. Nano Lett, 2013, 13: 5578-5584

112 Li H, Cheng F, Zhu Z, et al. Preparation and electrochemical performance of copper foam-supported amorphous silicon thin films for rechargeable lithium-ion batteries. J Alloys Compd, 2011, 509: 2919-2923

113 Wang YH, He Y, Xiao RJ, et al. Investigation of crack patterns and cyclic performance of Ti-Si nanocomposite thin film anodes for lithium ion batteries. J Power Sources, 2012, 202: 236-245

114 Guo $\mathrm{S}$, Li H, Bai $\mathrm{H}$, et al. Ti/Si/Ti sandwich-like thin film as the anode of lithium-ion batteries. J Power Sources, 2014, 248: 1141-1148

115 Zhang Q, Liu J, Wu ZY, et al. 3D nanostructured multilayer $\mathrm{Si} / \mathrm{Al}$ film with excellent cycle performance as anode material for lithium-ion battery. J Alloys Compd, 2016, 657: 559-564

116 Hatchard TD, Topple JM, Fleischauer MD, et al. Electrochemical performance of SiAlSn films prepared by combinatorial sputtering. Electrochem Solid-State Lett, 2003, 6: A129

117 Fleischauer MD, Obrovac MN, Dahn JR. Al-Si thin-film negative electrodes for Li-ion batteries. J Electrochem Soc, 2008, 155: A851

118 Suk J, Kim DY, Kim DW, et al. Electrodeposited 3D porous silicon/copper films with excellent stability and high rate performance for lithium-ion batteries. J Mater Chem A, 2014, 2: 2478-2481

119 Wang C, Chui YS, Ma R, et al. A three-dimensional graphene scaffold supported thin film silicon anode for lithium-ion batteries. J Mater Chem A, 2013, 1: 10092-10098

120 Chen LB, Xie JY, Yu HC, et al. Si-Al thin film anode material with superior cycle performance and rate capability for lithium ion batteries. Electrochim Acta, 2008, 53: 8149-8153

121 Krishnan R, Lu TM, Koratkar N. Functionally strain-graded nanoscoops for high power Li-ion battery anodes. Nano Lett, 2011, 11: 377-384

122 Zhou W, Upreti S, Whittingham MS. Electrochemical performance of Al-Si-graphite composite as anode for lithium-ion batteries. Electrochem Commun, 2011, 13: 158-161

123 Huang $\mathrm{S}$, Wen $\mathrm{Z}$, Zhang J, et al. $\mathrm{Li}_{4} \mathrm{Ti}_{5} \mathrm{O}_{12} / \mathrm{Ag}$ composite as electrode materials for lithium-ion battery. Solid State Ion, 2006, 177: 851-855

124 Dominko R, Gaberscek M, Bele M, et al. Carbon nanocoatings on active materials for Li-ion batteries. J Eur Ceramic Soc, 2007, 27: 909-913

125 Liu H, Feng Y, Wang K, et al. Synthesis and electrochemical properties of $\mathrm{Li}_{4} \mathrm{Ti}_{5} \mathrm{O}_{12} / \mathrm{C}$ composite by the PVB rheological phase method. J Phys Chem Solids, 2008, 69: 2037-2040

126 Huang J, Jiang $\mathrm{Z}$. The preparation and characterization of $\mathrm{Li}_{4} \mathrm{Ti}_{5} \mathrm{O}_{12} /$ carbon nano-tubes for lithium ion battery. Electrochim Acta, 2008, 53: 7756-7759

127 Yang L, Gao L. $\mathrm{Li}_{4} \mathrm{Ti}_{5} \mathrm{O}_{12} / \mathrm{C}$ composite electrode material synthesized involving conductive carbon precursor for Li-ion battery. J Alloys Compd, 2009, 485: 93-97

128 Wolfenstine J, Lee U, Allen JL. Electrical conductivity and rate-capability of $\mathrm{Li}_{4} \mathrm{Ti}_{5} \mathrm{O}_{12}$ as a function of heat-treatment atmosphere. J 
Power Sources, 2006, 154: 287-289

129 Li G, Zhang Z, Wang R, et al. Effect of trace Al surface doping on the structure, surface chemistry and low temperature performance of $\mathrm{LiNi}_{0.5} \mathrm{Co}_{0.2} \mathrm{Mn}_{0.3} \mathrm{O}_{2}$ cathode. Electrochim Acta, 2016, 212: 399-407

130 Hao YJ, Lai QY, Lu JZ, et al. Effects of dopant on the electrochemical properties of $\mathrm{Li}_{4} \mathrm{Ti}_{5} \mathrm{O}_{12}$ anode materials. Ion, 2007, 13: 369-373

131 Kubiak P, Garcia A, Womes M, et al. Phase transition in the spinel $\mathrm{Li}_{4} \mathrm{Ti}_{5} \mathrm{O}_{12}$ induced by lithium insertion. J Power Sources, 2003, 119121: $626-630$

132 Huang S, Wen Z, Gu Z, et al. Preparation and cycling performance of $\mathrm{Al}^{3+}$ and $\mathrm{F}^{-}$co-substituted compounds $\mathrm{Li}_{4} \mathrm{Al}_{x} \mathrm{Ti}_{5-x} \mathrm{~F}_{y} \mathrm{O}_{12-y}$. Electrochim Acta, 2005, 50: 4057-4062

133 Huang S, Wen Z, Zhu X, et al. Effects of dopant on the electrochemical performance of $\mathrm{Li}_{4} \mathrm{Ti}_{5} \mathrm{O}_{12}$ as electrode material for lithium ion batteries. J Power Sources, 2007, 165: 408-412

134 Yu H, Zhang X, Jalbout AF, et al. High-rate characteristics of novel anode $\mathrm{Li}_{4} \mathrm{Ti}_{5} \mathrm{O}_{12}$ /polyacene materials for $\mathrm{Li}$-ion secondary batteries. Electrochim Acta, 2008, 53: 4200-4204

135 Tabuchi T, Yasuda H, Yamachi M. Mechanism of Li-doping into $\mathrm{Li}_{4} \mathrm{Ti}_{5} \mathrm{O}_{12}$ negative active material for $\mathrm{Li}$-ion cells by new chemical method. J Power Sources, 2006, 162: 813-817

136 Wolfenstine J, Allen JL. Electrical conductivity and charge compensation in Ta doped $\mathrm{Li}_{4} \mathrm{Ti}_{5} \mathrm{O}_{12}$. J Power Sources, 2008, 180: 582-585

137 Martha SK, Nanda J, Veith GM, et al. Electrochemical and rate performance study of high-voltage lithium-rich composition: $\mathrm{Li}_{1.2} \mathrm{Mn}_{0.525} \mathrm{Ni}_{0.175} \mathrm{Co}_{0.1} \mathrm{O}_{2}$. J Power Sources, 2012, 199: 220-226

138 Thackeray MM, Kang SH, Johnson CS, et al. Comments on the structural complexity of lithium-rich $\mathrm{Li}_{1+x} \mathrm{M}_{1-x} \mathrm{O}_{2}$ electrodes ( $\mathrm{M}=\mathrm{Mn}, \mathrm{Ni}, \mathrm{Co})$ for lithium batteries. Electrochem Commun, 2006, 8: 1531-1538

139 Iftekhar M, Drewett NE, Armstrong AR, et al. Characterization of aluminum doped lithium-manganese rich composites for higher rate lithium-ion cathodes. J Electrochem Soc, 2014, 161: A2109-A2116

$140 \mathrm{He}$ Z, Wang Z, Chen $\mathrm{H}$, et al. Electrochemical performance of zirconium doped lithium rich layered $\mathrm{Li}_{1.2} \mathrm{Mn}_{0.54} \mathrm{Ni}_{0.13} \mathrm{Co}_{0.13} \mathrm{O}_{2}$ oxide with porous hollow structure. J Power Sources, 2015, 299: 334-341

141 Sethuprakhash V, Basirun WJ. Structural and electrochemical investigation of $\mathrm{LiNi}_{0.8} \mathrm{Co}_{0.2-x} \mathrm{M}_{x} \mathrm{O}_{2}(\mathrm{M}=\mathrm{Al}, \mathrm{Al}+\mathrm{Mg}, \mathrm{Al}+\mathrm{Mg}+\mathrm{Fe})$ synthesized by solid-state method. Ion, 2008, 14: 501-507

142 Liu X, Li D, Mo Q, et al. Facile synthesis of aluminum-doped $\mathrm{LiNi}_{0.5} \mathrm{Mn}_{1.5} \mathrm{O}_{4}$ hollow microspheres and their electrochemical performance for high-voltage Li-ion batteries. J Alloys Compd, 2014, 609: 54-59

143 Locati C, Lafont U, Simonin L, et al. Mg-doped $\mathrm{LiNi}_{0.5} \mathrm{Mn}_{1.5} \mathrm{O}_{4}$ spinel for cathode materials. J Power Sources, 2007, 174: 847-851

144 Lin M, Wang SH, Gong ZL, et al. A strategy to improve cyclic performance of $\mathrm{LiNi}_{0.5} \mathrm{Mn}_{1.5} \mathrm{O}_{4}$ in a wide voltage region by Ti-doping. J Electrochem Soc, 2013, 160: A3036-A3040

145 Qi X, Blizanac B, DuPasquier A, et al. Influence of thermal treated carbon black conductive additive on the performance of high voltage spinel $\mathrm{Cr}$-doped $\mathrm{LiNi}_{0.5} \mathrm{Mn}_{1.5} \mathrm{O}_{4}$ composite cathode electrode. J Electrochem Soc, 2015, 162: A339-A343

146 Liu J, Manthiram A. Improved electrochemical performance of the $5 \mathrm{~V}$ spinel cathode $\mathrm{LiMn}_{1.5} \mathrm{Ni}_{0.42} \mathrm{Zn}_{0.08} \mathrm{O}_{4}$ by surface modification. J Electrochem Soc, 2009, 156: A66

147 Şahan $\mathrm{H}$, Göktepe $\mathrm{H}$, Patat, et al. Effect of the $\mathrm{Cr}_{2} \mathrm{O}_{3}$ coating on electrochemical properties of spinel $\mathrm{LiMn}_{2} \mathrm{O}_{4}$ as a cathode material for lithium battery applications. Solid State Ion, 2010, 181: 1437-1444

148 Thirunakaran R, Kim KT, Kang YM, et al. Adipic acid assisted, sol-gel route for synthesis of $\mathrm{LiCr}_{x} \mathrm{Mn}_{2-x} \mathrm{O}_{4}$ cathode material. J Power Sources, 2004, 137: 100-104

149 Arumugam D, Kalaignan GP, Vediappan K, et al. Synthesis and electrochemical characterizations of nano-scaled $\mathrm{Zn}$ doped $\mathrm{LiMn}_{2} \mathrm{O}_{4}$ cathode materials for rechargeable lithium batteries. Electrochim Acta, 2010, 55: 8439-8444

150 Raja MW, Mahanty S, Basu RN. Influence of S and Ni co-doping on structure, band gap and electrochemical properties of lithium manganese oxide synthesized by soft chemical method. J Power Sources, 2009, 192: 618-626

151 Wu YP, Rahm E, Holze R. Effects of heteroatoms on electrochemical performance of electrode materials for lithium ion batteries. Electrochim Acta, 2002, 47: 3491-3507

152 Patoux S, Sannier L, Lignier H, et al. High voltage nickel manganese spinel oxides for Li-ion batteries. Electrochim Acta, 2008, 53: 4137-4145

153 Guo D, Li B, Chang Z, et al. Facile synthesis of $\mathrm{LiAl}_{0.1} \mathrm{Mn}_{1.9} \mathrm{O}_{4}$ as cathode material for lithium ion batteries: towards rate and cycling capabilities at an elevated temperature. Electrochim Acta, 2014, 134: $338-346$

154 Yuan A, Tian L, Xu W, et al. Al-doped spinel $\mathrm{LiAl}_{0.1} \mathrm{Mn}_{1.9} \mathrm{O}_{4}$ with improved high-rate cyclability in aqueous electrolyte. J Power Sources, 2010, 195: 5032-5038

155 Ryu WH, Eom JY, Yin RZ, et al. Synergistic effects of various morphologies and $\mathrm{Al}$ doping of spinel $\mathrm{LiMn}_{2} \mathrm{O}_{4}$ nanostructures on the electrochemical performance of lithium-rechargeable batteries. J Mater Chem, 2011, 21: 15337-15342

156 Wang JL, Li ZH, Yang J, et al. Effect of Al-doping on the electrochemical properties of a three-dimensionally porous lithium manganese oxide for lithium-ion batteries. Electrochim Acta, 2012, 75: 115-122

157 Thackeray MM, Kang $\mathrm{SH}$, Johnson CS, et al. $\mathrm{Li}_{2} \mathrm{MnO}_{3}$-stabilized $\mathrm{LiMO}_{2}(\mathrm{M}=\mathrm{Mn}, \mathrm{Ni}, \mathrm{Co})$ electrodes for lithium-ion batteries. J Mater Chem, 2007, 17: 3112-3125

158 Jafta CJ, Ozoemena KI, Mathe MK, et al. Synthesis, characterisation and electrochemical intercalation kinetics of nanostructured aluminium-doped $\mathrm{Li}\left[\mathrm{Li}_{0.2} \mathrm{Mn}_{0.54} \mathrm{Ni}_{0.13} \mathrm{Co}_{0.13}\right] \mathrm{O}_{2}$ cathode material for lithium ion battery. Electrochim Acta, 2012, 85: 411-422

159 Trease NM, Seymour ID, Radin MD, et al. Identifying the Distribution of $\mathrm{Al}^{3+}$ in $\mathrm{LiNi}_{0.8} \mathrm{Co}_{0.15} \mathrm{Al}_{0.05} \mathrm{O}_{2}$. Chem Mater, 2016, 28 : $8170-8180$

160 Lin JY, Hsu CC, Ho HP, et al. Sol-gel synthesis of aluminum doped lithium titanate anode material for lithium ion batteries. Electrochim Acta, 2013, 87: 126-132

161 Le HTT, Kalubarme RS, Ngo DT, et al. Citrate gel synthesis of aluminum-doped lithium lanthanum titanate solid electrolyte for application in organic-type lithium-oxygen batteries. J Power Sources, 2015, 274: 1188-1199

162 Zhang L, Zhang J, Liu Y, et al. Al doped-ZnO nanoparticles implanted in reduced graphene oxide with improved electrochemical properties for lithium ion batteries. Mater Lett, 2016, 165: 165-168

163 Hou C, Ma Y, Dong X, et al. Facile synthesis of $\mathrm{LiCo}_{1 / 3} \mathrm{Ni}_{1 / 3} \mathrm{Mn}_{1 / 3} \mathrm{O}_{2} / \mathrm{Al}(\mathrm{OH})_{3}$ composite as a high-performance cathode material for lithium ion cells. J Alloys Compd, 2016, 656: 849-853

164 Jang SB, Kang SH, Amine K, et al. Synthesis and improved electrochemical performance of $\mathrm{Al}(\mathrm{OH})_{3}$-coated $\mathrm{Li}\left[\mathrm{Ni}_{1 / 3} \mathrm{Mn}_{1 / 3} \mathrm{Co}_{1 / 3}\right] \mathrm{O}_{2}$ cathode materials at elevated temperature. Electrochim Acta, 2005, 50: 4168-4173

165 Kang YJ, Kim JH, Lee SW, et al. The effect of $\mathrm{Al}(\mathrm{OH})_{3}$ coating on the $\mathrm{Li}\left[\mathrm{Li}_{0.2} \mathrm{Ni}_{0.2} \mathrm{Mn}_{0.6}\right] \mathrm{O}_{2}$ cathode material for lithium secondary battery. Electrochim Acta, 2005, 50: 4784-4791 
Zgirski M, Riikonen KP, Touboltsev V, et al. Size dependent breakdown of superconductivity in ultranarrow nanowires. Nano Lett, 2005, 5: 1029-1033

167 Zgirski M, Riikonen KP, Touboltsev V, et al. Quantum fluctuations in ultranarrow superconducting aluminum nanowires. Phys Rev B, 2008, 77: 054508

168 Özer MM, Thompson JR, Weitering HH. Hard superconductivity of a soft metal in the quantum regime. Nat Phys, 2006, 2: 173-176

169 Guo, Wan LJ, Zhu CF, et al. Ordered Ni-Cu nanowire array with enhanced coercivity. Chem Mater, 2003, 15: 664-667

170 Bao J, Tie C, Xu Z, et al. Template synthesis of an array of nickel nanotubules and its magnetic behavior. Adv Mater, 2001, 13: 1631-1633

171 Ferré R, Ounadjela K, George JM, et al. Magnetization processes in nickel and cobalt electrodeposited nanowires. Phys Rev B, 1997, 56: 14066-14075

172 McGary PD, Tan L, Zou J, et al. Magnetic nanowires for acoustic sensors. J Appl Phys, 2006, 99: 08B310-08B310

173 Kim TH, Zhang XG, Nicholson DM, et al. Large discrete resistance jump at grain boundary in copper nanowire. Nano Lett, 2010, 10: 3096-3100

174 Datt G, Sen Bishwas M, Manivel Raja M, et al. Observation of magnetic anomalies in one-step solvothermally synthesized nickel-cobalt ferrite nanoparticles. Nanoscale, 2016, 8: 5200-5213 Granqvist CG. Transparent conductors as solar energy materials: a panoramic review. Sol Energ Mater Sol Cells, 2007, 91: 1529-1598

176 Lee EP, Peng Z, Cate DM, et al. Growing Pt nanowires as a densely packed array on metal gauze. J Am Chem Soc, 2007, 129: 10634-10635

177 Shaijumon MM, Perre E, Daffos B, et al. Nanoarchitectured 3D cathodes for Li-Ion microbatteries. Adv Mater, 2010, 22: 4978-4981

178 Taberna PL, Mitra S, Poizot $\mathrm{P}$, et al. High rate capabilities $\mathrm{Fe}_{3} \mathrm{O}_{4}$ based $\mathrm{Cu}$ nano-architectured electrodes for lithium-ion battery applications. Nat Mater, 2006, 5: 567-573

179 Au M, McWhorter S, Ajo H, et al. Free standing aluminum nanostructures as anodes for Li-ion rechargeable batteries. J Power Sources, 2010, 195: 3333-3337

180 Huber GW, Shabaker JW, Dumesic JA. Raney Ni-Sn catalyst for $\mathrm{H}_{2}$ production from biomass-derived hydrocarbons. Science, 2003, 300: 2075-2077

181 Sakintuna B, Lamaridarkrim F, Hirscher M. Metal hydride materials for solid hydrogen storage: a review. Int J Hydrogen Energ, 2007, 32: 1121-1140

182 Banerjee P, Perez I, Henn-Lecordier L, et al. Nanotubular metal-insulator-metal capacitor arrays for energy storage. Nat Nanotech, 2009, 4: 292-296

183 Portet C, Taberna PL, Simon P, et al. Modification of Al current collector surface by sol-gel deposit for carbon-carbon supercapacitor applications. Electrochim Acta, 2004, 49: 905-912

184 Lang X, Hirata A, Fujita T, et al. Nanoporous metal/oxide hybrid electrodes for electrochemical supercapacitors. Nat Nanotech, 2011, 6: 232-236

185 Liu Y, Hudak NS, Huber DL, et al. In situ transmission electron microscopy observation of pulverization of aluminum nanowires and evolution of the thin surface $\mathrm{Al}_{2} \mathrm{O}_{3}$ layers during lithiation-delithiation cycles. Nano Lett, 2011, 11: 4188-4194

186 Benson J, Boukhalfa S, Magasinski A, et al. Chemical vapor deposition of aluminum nanowires on metal substrates for electrical energy storage applications. ACS Nano, 2012, 6: 118-125

187 Rani JV, Kanakaiah V, Dadmal T, et al. Fluorinated natural graphite cathode for rechargeable ionic liquid based aluminum-ion battery.
J Electrochem Soc, 2013, 160: A1781-A1784

188 Rahman MA, Wang X, Wen C. High energy density metal-air batteries: a review. J Electrochem Soc, 2013, 160: A1759-A1771

189 Doche ML, Novel-Cattin F, Durand R, et al. Characterization of different grades of aluminum anodes for aluminum/air batteries. J Power Sources, 1997, 65: 197-205

190 Patnaik RSM, Ganesh S, Ashok G, et al. Heat management in aluminium/air batteries: sources of heat. J Power Sources, 1994, 50: 331-342

191 Rudd EJ, Gibbons DW. High energy density aluminum/oxygen cell. J Power Sources, 1994, 47: 329-340

192 Linden D, Reddy TB (3rd ed.). Handbook of Batteries. New York: McGraw-Hill, 1995

193 Tang Y, Lu L, Roesky HW, et al. The effect of zinc on the aluminum anode of the aluminum-air battery. J Power Sources, 2004, 138: 313-318

194 Jiang T, Chollier Brym MJ, Dubé G, et al. Electrodeposition of aluminium from ionic liquids: Part I-electrodeposition and surface morphology of aluminium from aluminium chloride $\left(\mathrm{AlCl}_{3}\right)$-1-ethyl-3-methylimidazolium chloride $([\mathrm{EMIm}] \mathrm{Cl})$ ionic liquids. Surface Coatings Tech, 2006, 201: 1-9

195 Jayaprakash N, Das SK, Archer LA. The rechargeable aluminumion battery. Chem Commun, 2011, 47: 12610-12612

196 Wang H, Gu S, Bai Y, et al. Anion-effects on electrochemical properties of ionic liquid electrolytes for rechargeable aluminum batteries. J Mater Chem A, 2015, 3: 22677-22686

197 Wang H, Gu S, Bai Y, et al. High-voltage and noncorrosive ionic liquid electrolyte used in rechargeable aluminum battery. ACS Appl Mater Interfaces, 2016, 8: 27444-27448

198 Sun XG, Fang Y, Jiang X, et al. Polymer gel electrolytes for application in aluminum deposition and rechargeable aluminum ion batteries. Chem Commun, 2016, 52: 292-295

$199 \mathrm{Gu} \mathrm{S}$, Wang $\mathrm{H}, \mathrm{Wu} \mathrm{C}$, et al. Confirming reversible $\mathrm{Al}^{3+}$ storage mechanism through intercalation of $\mathrm{Al}^{3+}$ into $\mathrm{V}_{2} \mathrm{O}_{5}$ nanowires in a rechargeable aluminum battery. Energ Storage Mater, 2017, 6: 9-17

200 Hudak NS. Chloroaluminate-Doped Conducting Polymers as Positive Electrodes in Rechargeable Aluminum Batteries. J Phys Chem C, 2014, 118: 5203-5215

201 Gifford PR. An aluminum/chlorine rechargeable cell employing a room temperature molten salt electrolyte. J Electrochem Soc, 1988, 135: $650-654$

202 Reed LD, Ortiz SN, Xiong M, et al. A rechargeable aluminum-ion battery utilizing a copper hexacyanoferrate cathode in an organic electrolyte. Chem Commun, 2015, 51: 14397-14400

203 Chiku M, Takeda H, Matsumura S, et al. Amorphous vanadium oxide/carbon composite positive electrode for rechargeable aluminum battery. ACS Appl Mater Interfaces, 2015, 7: 24385-24389

204 Lee S, Cho J. Critical requirements for rapid charging of rechargeable Al- and Li-ion batteries. Angew Chem Int Ed, 2015, 54: 9452-9455

205 Liu S, Ye SH, Li CZ, et al. Rechargeable aqueous lithium-ion battery of $\mathrm{TiO}_{2} / \mathrm{LiMn}_{2} \mathrm{O}_{4}$ with a high voltage. J Electrochem Soc, 2011, 158: A1490

206 Liu S, Hu JJ, Yan NF, et al. Aluminum storage behavior of anatase $\mathrm{TiO}_{2}$ nanotube arrays in aqueous solution for aluminum ion batteries. Energ Environ Sci, 2012, 5: 9743-9746

207 Liu Y, Sang S, Wu Q, et al. The electrochemical behavior of $\mathrm{Cl}^{-}$assisted $\mathrm{Al}^{3+}$ insertion into titanium dioxide nanotube arrays in aqueous solution for aluminum ion batteries. Electrochim Acta, 2014, 143: $340-346$

208 Lin MC, Gong M, Lu B, et al. An ultrafast rechargeable aluminium- 
ion battery. Nature, 2015, 520: 324-328

209 Wu Y, Gong M, Lin MC, et al. 3D graphitic foams derived from chloroaluminate anion intercalation for ultrafast aluminum-ion battery. Adv Mater, 2016, 28: 9218-9222

210 Chen H, Guo F, Liu Y, et al. A defect-free principle for advanced graphene cathode of aluminum-ion battery. Adv Mater, 2017, 29: 1605958

211 Yu X, Wang B, Gong D, et al. Graphene nanoribbons on highly porous $3 \mathrm{D}$ graphene for high-capacity and ultrastable Al-ion batteries. Adv Mater, 2017, 29: 1604118

212 Jung SC, Kang YJ, Yoo DJ, et al. Flexible few-layered graphene for the ultrafast rechargeable aluminum-ion battery. J Phys Chem C, 2016, 120: 13384-13389

213 Wang $\mathrm{H}$, Bai $\mathrm{Y}$, Chen $\mathrm{S}$, et al. Binder-free $\mathrm{V}_{2} \mathrm{O}_{5}$ cathode for greener rechargeable aluminum battery. ACS Appl Mater Interfaces, 2015, 7: $80-84$

214 Wang F, Yu F, Wang X, et al. Aqueous rechargeable zinc/aluminum ion battery with good cycling performance. ACS Appl Mater Interfaces, 2016, 8: 9022-9029

215 Allman VR. Doppelschichtstrukturen mit brucitähnlichen Schichtionen $\left[\mathrm{Me}(\mathrm{II})_{1-x} \mathrm{Me}(\mathrm{III})_{x}(\mathrm{OH})_{2}\right]^{x+}$. Chimia, 1970, 24 99-108

216 Intissar M, Segni R, Payen C, et al. Trivalent cation substitution effect into layered double hydroxides $\mathrm{Co}_{2} \mathrm{Fe}_{y} \mathrm{Al}_{1-y}(\mathrm{OH})_{6} \mathrm{Cl} \cdot n \mathrm{H}_{2} \mathrm{O}$ : study of the local order. J Solid State Chem, 2002, 167: 508-516

217 Zhao MQ, Liu XF, Zhang Q, et al. Graphene/single-walled carbon nanotube hybrids: one-step catalytic growth and applications for high-rate Li-S batteries. ACS Nano, 2012, 6: 10759-10769

218 Taibi M, Ammar S, Jouini N, et al. Layered nickel hydroxide salts: synthesis, characterization and magnetic behaviour in relation to the basal spacing. J Mater Chem, 2002, 12: 3238-3244

219 Nakahira A, Murase H, Yasuda H. Effect of application of a high magnetic field on the microstructure of Fe substituted layered double hydroxide clay for a magnetic application. J Appl Phys, 2007, 101: 09N516-09N516

220 Tichit D, Ortiz MJM, Francová D, et al. Design of nanostructured multifunctional Pd-based catalysts from layered double hydroxides precursors. Appl Catal A-General, 2007, 318: 170-177

221 Nakahira A, Kubo T, Murase H. Synthesis of LDH-type clay substituted with $\mathrm{Fe}$ and $\mathrm{Ni}$ ion for arsenic removal and its application to magnetic separation. IEEE Trans Magn, 2007, 43: 2442-2444

222 Prasanna SV, Kamath PV, Shivakumara C. Synthesis and characterization of layered double hydroxides (LDHs) with intercalated chromate ions. Mater Res Bull, 2007, 42: 1028-1039

223 Kamath PV, Annal Therese GH, Gopalakrishnan J. On the existence of hydrotalcite-like phases in the absence of trivalent cations. J Solid State Chem, 1997, 128: 38-41

224 Sugimoto A. Preparation and characterization of Ni/Al-layered double hydroxide. J Electrochem Soc, 1999, 146: 1251-1255

225 Wang T, Chen S, Pang $\mathrm{H}$, et al. $\mathrm{MoS}_{2}$-based nanocomposites for electrochemical energy storage. Adv Sci, 2017, 4: 1600289

226 Sato Y, Takeuchi S, Kobayakawa K. Cause of the memory effect observed in alkaline secondary batteries using nickel electrode. J Power Sources, 2001, 93: 20-24

227 Corrigan DA. Electrochemical and spectroscopic evidence on the participation of quadrivalent nickel in the nickel hydroxide redox reaction. J Electrochem Soc, 1989, 136: 613-619

228 Delahaye-Vidal A, Figlarz M. Textural and structural studies on nickel hydroxide electrodes. II. Turbostratic nickel (II) hydroxide submitted to electrochemical redox cycling. J Appl Electrochem, 1987, 17: 589-599 on the electrochemical performances of a layered double hydroxide. J Power Sources, 2011, 196: 1569-1577

$230 \mathrm{Hu}$ WK, Noréus D. Alpha nickel hydroxides as lightweight nickel electrode materials for alkaline rechargeable cells. Chem Mater, 2003, 15: 974-978

231 Dai J, Li SFY, Xiao TD, et al. Structural stability of aluminum stabilized alpha nickel hydroxide as a positive electrode material for alkaline secondary batteries. J Power Sources, 2000, 89: 40-45

232 Li Y, Li W, Chou S, et al. Synthesis, characterization and electrochemical properties of aluminum-substituted alpha- $\mathrm{Ni}(\mathrm{OH})_{2}$ hollow spheres. J Alloys Compd, 2008, 456: 339-343

233 Liang J, Ma R, Iyi N, et al. Topochemical synthesis, anion exchange, and exfoliation of $\mathrm{Co}-\mathrm{Ni}$ layered double hydroxides: a route to positively charged $\mathrm{Co}-\mathrm{Ni}$ hydroxide nanosheets with tunable composition. Chem Mater, 2010, 22: 371-378

234 Delmas C, Borthomieu Y. Chimie douce reactions: a new route to obtain well crystallized layer double hydroxides. J Solid State Chem, 1993, 104: 345-352

235 Iwasaki T, Yoshii H, Nakamura H, et al. Simple and rapid synthesis of Ni-Fe layered double hydroxide by a new mechanochemical method. Appl Clay Sci, 2012, 58: 120-124

236 Axmann P, Glemser O. Nickel hydroxide as a matrix for unusual valencies: the electrochemical behaviour of metal(III)-ion-substituted nickel hydroxides of the pyroaurite type. J Alloys Compd, 1997, 246: 232-241

237 Chen H, Wang JM, Zhao YL, et al. Electrochemical performance of $\mathrm{Zn}$-substituted $\mathrm{Ni}(\mathrm{OH})_{2}$ for alkaline rechargeable batteries. J Solid State Electrochem, 2005, 9: 421-428

238 Tessier C. Structural and textural evolution of zinc-substituted nickel hydroxide electrode materials upon ageing in $\mathrm{KOH}$ and upon redox cycling. Solid State Ion, 2000, 133: 11-23

239 Wu MY, Wang JM, Zhang JQ, et al. Effects of coprecipitated manganese on the structure and electrochemical performance of Al-substituted $\alpha$-nickel hydroxide. J Solid State Electrochem, 2006, 10: 411-415

240 Kameda T, Hoshi K, Yoshioka T. Preparation of Cu-Allayered double hydroxide intercalated with ethylenediaminetetraacetate by coprecipitation and its uptake of rare earth ions from aqueous solution. Solid State Sci, 2013, 17: 28-34

241 Lei L, Hu M, Gao X, et al. The effect of the interlayer anions on the electrochemical performance of layered double hydroxide electrode materials. Electrochim Acta, 2008, 54: 671-676

$242 \mathrm{Hu}$ M, Gao X, Lei L, et al. Behavior of a layered double hydroxide under high current density charge and discharge cycles. J Phys Chem C, 2009, 113: 7448-7455

243 Li J, Shangguan E, Guo D, et al. Synthesis, characterization and electrochemical performance of high-density aluminum substituted $a$-nickel hydroxide cathode material for nickel-based rechargeable batteries. J Power Sources, 2014, 270: 121-130

$244 \mathrm{Hu}$ M, Ji X, Lei L, et al. The effect of cobalt on the electrochemical performances of $\mathrm{Ni}-\mathrm{Al}$ layered double hydroxides used in $\mathrm{Ni}-\mathrm{M}(\mathrm{H})$ battery. J Alloys Compd, 2013, 578: 17-25

245 Chen H, Wang JM, Pan T, et al. The structure and electrochemical performance of spherical Al-substituted $\alpha-\mathrm{Ni}(\mathrm{OH})_{2}$ for alkaline rechargeable batteries. J Power Sources, 2005, 143: 243-255

246 Kim Y, Kim D. Synthesis of high-density nickel cobalt aluminum hydroxide by continuous coprecipitation method. ACS Appl Mater Interfaces, 2012, 4: 586-589

247 Deroy A, Besse J. Evolution of protonic conduction in some synthetic anionic clays. Solid State Ion, 1991, 46: 95-101

248 Lee K, Nam JH, Lee JH, et al. Methanol and proton transport control by using layered double hydroxide nanoplatelets for direct 
methanol fuel cell. Electrochem Commun, 2005, 7: 113-118

Béléké AB, Mizuhata M. Electrochemical properties of nickel-aluminum layered double hydroxide/carbon composite fabricated by liquid phase deposition. J Power Sources, 2010, 195: 7669-7676

250 Béléké $\mathrm{AB}$, Higuchi $\mathrm{E}$, Inoue $\mathrm{H}$, et al. Effects of the composition on the properties of nickel-aluminum layered double hydroxide/carbon (Ni-Al LDH/C) composite fabricated by liquid phase deposition (LPD). J Power Sources, 2013, 225: 215-220

251 Béléké $\mathrm{AB}$, Higuchi $\mathrm{E}$, Inoue $\mathrm{H}$, et al. Durability of nickel-metal hydride (Ni-MH) battery cathode using nickel-aluminum layered double hydroxide/carbon (Ni-Al LDH/C) composite. J Power Sources, 2014, 247: 572-578

252 Mizuhata M, Hosokawa A, Béléké AB, et al. ECS Trans, 2009, 19: 41-46

253 Yu JG, Yu HG, Cheng B, et al. The effect of calcination temperature on the surface microstructure and photocatalytic activity of $\mathrm{TiO}_{2}$ thin films prepared by liquid phase deposition. J Phys Chem B, 2003, 107: 13871-13879

254 Deki S, Yu Yu Ko H, Fujita T, et al. Synthesis and microstructure of metal oxide thin films containing metal nanoparticles by liquid phase deposition (LPD) method. Eur Phys J D, 2001, 16: 325-328 Deki S, Iizuka S, Horie A, et al. Liquid-phase infiltration (LPI) process for the fabrication of highly nano-ordered materials. Chem Mater, 2004, 16: 1747-1750

256 Deki S, Iizuka S, Akamatsu K, et al. Fabrication and structural control of $\mathrm{Fe} / \mathrm{Ti}$ oxide thin films with graded compositional profiles by liquid phase deposition. J Am Ceramic Soc, 2005, 88: 731-736

257 Deki S, Hosokawa A, Béléké $\mathrm{AB}$, et al. $\alpha-\mathrm{Ni}(\mathrm{OH})_{2}$ thin films fabricated by liquid phase deposition method. Thin Solid Films, 2009, 517: 1546-1554

258 Gao Z, Wang J, Li Z, et al. Graphene nanosheet $/ \mathrm{Ni}^{2+} / \mathrm{Al}^{3+}$ layered double-hydroxide composite as a novel electrode for a supercapacitor. Chem Mater, 2011, 23: 3509-3516

259 Zhang L, Wang J, Zhu J, et al. 3D porous layered double hydroxides grown on graphene as advanced electrochemical pseudocapacitor materials. J Mater Chem A, 2013, 1: 9046-9053

260 Zhang G, Xiao X, Li B, et al. Transition metal oxides with one-dimensional/one-dimensional-analogue nanostructures for advanced supercapacitors. J Mater Chem A, 2017, 5: 8155-8186

261 Hu J, Lei G, Lu Z, et al. Alternating assembly of Ni-Al layered double hydroxide and graphene for high-rate alkaline battery cathode. Chem Commun, 2015, 51: 9983-9986

262 Liu Z, Ma R, Osada M, et al. Synthesis, anion exchange, and delamination of $\mathrm{Co}-\mathrm{Al}$ layered double hydroxide: assembly of the exfoliated nanosheet/polyanion composite films and magneto-optical studies. J Am Chem Soc, 2006, 128: 4872-4880

263 Chen H, Wang JM, Pan T, et al. Physicochemical properties and electrochemical performance of Al-substituted $\alpha-\mathrm{Ni}(\mathrm{OH})_{2}$ with additives for Ni-metal hydride batteries. J Electrochem Soc, 2003, 150: A1399
264 Feng Z, Yang Z, Yang B, et al. The application of Co-Al-hydrotalcite as a novel additive of positive material for nickel-metal hydride secondary cells. J Power Sources, 2014, 266: 22-28

265 Gong M, Li Y, Zhang H, et al. Ultrafast high-capacity NiZn battery with NiAlCo-layered double hydroxide. Energ Environ Sci, 2014, 7: 2025-2032

266 Xie X, Yang Z, Feng Z, et al. Effect of dodecyl sulfate anions on the electrochemical performances of zinc-aluminum-hydrotalcite as anode material for zinc/nickel secondary batteries. Electrochim Acta, 2014, 149: 101-107

267 Fan X, Yang Z, Xie X, et al. The electrochemical behaviors of $\mathrm{Zn}-\mathrm{Al}-\mathrm{La}-\mathrm{hyd}$ rotalcite in $\mathrm{Zn}-\mathrm{Ni}$ secondary cells. J Power Sources, 2013, 241: 404-409

268 Wang T, Yang Z, Yang B, et al. The electrochemical performances of $\mathrm{Zn}-\mathrm{Sn}-\mathrm{Al}$-hydrotalcites in $\mathrm{Zn}-\mathrm{Ni}$ secondary cells. J Power Sources, 2014, 257: 174-180

269 Wen X, Yang Z, Xie X, et al. The effects of element $\mathrm{Cu}$ on the electrochemical performances of zinc-aluminum-hydrotalcites in zinc/nickel secondary battery. Electrochim Acta, 2015, 180: 451-459

270 Yang B, Yang Z, Wang R, et al. Layered double hydroxide/carbon nanotubes composite as a high performance anode material for $\mathrm{Ni}-\mathrm{Zn}$ secondary batteries. Electrochim Acta, 2013, 111: 581-587

271 Li WH, Zeng LC, Wu Y, et al. Nanostructured electrode materials for lithium-ion and sodium-ion batteries via electrospinning. Sci China Mater, 2016, 59: 287-321

272 C. Massé R, Uchaker E, Cao G, et al. Beyond Li-ion: electrode materials for sodium- and magnesium-ion batteries. Sci China Mater, 2015, 58: 715-766

Acknowledgments This work was supported by the Program for New Century Excellent Talents of the University in China (NCET-13-0645) and the National Natural Science Foundation of China (21201010, 21671170 and 21673203), the Innovation Scientists and Technicians Troop Construction Projects of Henan Province (164200510018), the Program for Innovative Research Team (in Science and Technology) in the University of Henan Province (14IRTSTHN004), the Six Talent Plan (2015-XCL030), and Qinglan Project. We also acknowledge the Priority Academic Program Development of Jiangsu Higher Education Institutions, the Undergraduate Scientific Research Innovation Projects in Jiangsu province (201611117047Y) and the technical support we received from the Testing Center of Yangzhou University.

Author contributions Qiu J, Zhao M conducted the collection and arrangement of literatures, wrote and modified the manuscript. Zhao Q helped to collect and arrange the literatures. Xu Y, Zhang L, Lu X helped modify the manuscript. Pang $\mathrm{H}$ conceived the project and modified the manuscript. All authors contributed to the general discussion.

Conflict of interest The authors declare that they have no conflict of interest. 


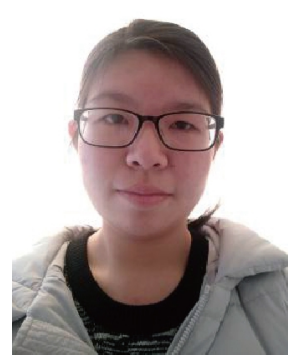

Jiaqing Qiu is a student at Yangzhou University, under Prof. Pang's supervision. Her interest focuses on the nanomaterials for energy storage.
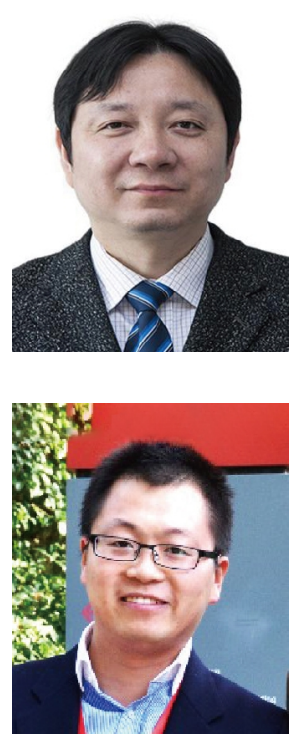

Huaiguo Xue received his $\mathrm{PhD}$ degree in polymer chemistry from Zhejiang University in 2002. He is currently a professor of physical chemistry and the dean of the College of Chemistry and Chemical Engineering at Yangzhou University. His research interests focus on electrochemistry, functional polymer and biosensors.
Huan Pang received his PhD degree from Nanjing University in 2011. He then founded his research group in Anyang Normal University where he was appointed as a distinguished professor in 2013. He has now jointed Yangzhou University as a university distinguished professor. He has published more than 110 papers in peer-reviewed journals including Chemical Society Reviews, Advanced Materials, Energy Environ. Sci., with 3900 citations (H-index=33). His research interests include the development of inorganic nanostructures and their applications in flexible electronics with a focus on energy devices.

\section{铝基材料在先进的电池系统方面的应用}

邱嘉晴, 赵明明, 赵群星, 徐玉霞, 张丽, 陆欣, 薛怀国, 庞欢*

摘要 微/纳米铝基材料用作可持续、可靠、高效电化学储能材料一直是近些年的研究热点. 本文主要论述了铝基电极材料在锂离子电池 方面的应用(材料包括氧化铝、氟化铝、磷酸铝、氢氧化铝以及一些铝基复合材料, 包含碳、硅、金属和过渡金属氧化物), 铝离子电池与 镍氢碱性二次电池的发展. 对近年来发现的方法论、相关的电荷存储机制、纳米结构与电化学性能之间的关系、最新的研究成果以及 它们的潜在应用进行了总结. 此外, 提到了近年来电极材料发展过程中遇到的相关挑战, 并且对未来发展微/纳米铝基材料于先进的电池 系统进行了展望. 